Submitted to Mass Spectrom. Rev.

REVISED Version: 2 August 2020

Guest Editor: Prof. Steen Brønsted Nielsen

\title{
Organometallic Gas-Phase Ion Chemistry and Catalysis: Insights into the Use of Metal Catalysts to Promote Selectivity in the Reactions of Carboxylic Acids and Their Derivatives. ${ }^{\dagger}$
}

\author{
Richard A. J. O’Hair*a,b
}

(a) School of Chemistry, University of Melbourne, Victoria 3010, Australia. Fax: +61

39347 5180; Tel: +61 38344 2452; Email: rohair@unimelb.edu.au

(b) Bio21 Institute of Molecular Science and Biotechnology, The University of Melbourne, Victoria 3010, Australia.

* Correspondence and PROOFS to: Professor Richard O’Hair:

Fax: +61 39347 5180; Tel: +61 38344 2452; E-mail: rohair@unimelb.edu.au

$\dagger$ Dedicated to Prof. Einar Uggerud in recognition of his contributions to this journal and the field of Physical Organic Chemistry.

Running title: Metal-Catalyzed Reactions of Carboxylic Acids

This is the author manuscript accepted for publication and undergone full peer review but has not been through the copyediting, typesetting, pagination and proofreading process, which may lead to differences between this version and the Version of Record. Please cite this article as doi: 10.1002/mas.21654.

This article is protected by copyright. All rights reserved. 


\begin{abstract}
Carboxylic acids are valuable organic substrates as they are widely available, easy to handle and exhibit structural and functional variety. While they are used in many standard synthetic protocols, over the past two decades numerous studies have explored new modes of metal- mediated reactivity of carboxylic acids and their derivatives. Mass spectrometry-based studies can provide fundamental mechanistic insights into these new modes of reactivity. Here gas-phase models for the following catalytic transformations of carboxylic acids and their derivatives are reviewed: protodecarboxylation; dehydration; decarbonylation; reaction as coordinated bases in $\mathrm{C}-\mathrm{H}$ bond activation; remote functionalization and decarboxylative $\mathrm{C}-\mathrm{C}$ bond coupling. In each case the catalytic problem is defined, insights from gas-phase studies are highlighted, comparisons with condensed-phase systems are made and perspectives are reached. Finally, the potential role for mechanistic studies that integrate both gas- and condensed-phase studies is highlighted by recent studies on the discovery of new catalysts for the selective decomposition of formic acid and the invention of the new ExIn (extrusion-insertion) class of reactions for the synthesis of amides, thioamides and amidines.
\end{abstract}

Keywords for indexing: Carboxylic acid; $\mathrm{C}-\mathrm{H}$ bond activation; $\mathrm{C}-\mathrm{C}$ bond activation; Decarbonylation; Decarboxylation; Dehydration

\title{
I. Introduction
}

\section{A. Background and Scope.}

Mass spectrometry (MS) has played a key role in uncovering the fundamental modes of gas-phase reactivity of organic substrates towards metal ions (Eller, 1993; Eller\&Schwarz, 1991), inorganic (Fisher, 2001; Rodgers\&Armentrout, 2004A;

This article is protected by copyright. All rights reserved. 
Rodgers\&Armentrout, 2016) and organometallic complexes (Richardson\&Plattner, 2007), and metal clusters (Armentrout, 2001; O'Hair\& Khairallah, 2004; Armentrout, 2010; Armentrout, 2014) and in defining metal ion interactions in biological systems (Rodgers\&Armentrout, 2004B) and key thermochemical quantities (Armentrout\&Beauchamp, 1989; Simoes\&Beauchamp, 1990; Armentrout, 1999). A powerful aspect of gas-phase studies is that the stoichiometries of individual ions can be controlled via mass selection from mixtures of ions of different $m / z$ ratios, which allows the roles of charge and oxidation state, ligands and cluster size in catalysis to be examined in detail (Schwarz, 2014; Schwarz, 2015A). Model systems used to establish key mechanistic aspects associated with heterogenous catalysis have been reviewed (Lang et al., 2007; Lang\& Bernhardt, 2012). The historical evolution of metal-catalyzed reactions in the gas phase has been highlighted in a review (O'Hair, 2015), while the interplay between mass spectrometry and computational chemistry in defining the mechanistic aspects of catalysis has been highlighted in recent reviews (Schwarz, 2017A; Cheng et al., 2019).

The advent of electrospray ionization (Fenn et al., 1989; Colton et al., 1995; Traeger, 2000; Henderson\&McIndoe, 2004; McIndoe\&Vikse, 2019) has allowed solution-phase intermediates associated with metal catalysts to be interrogated via MS (Chen, 2003; Santos, 2008; Santos, 2010A\&B; Schröder, 2012; Yunker et al., 2014; Vikse\&McIndoe, 2015; Iacobucci et al., 2016), their temporal evolution to be examined (Vikse et al., 2010; Vikse et al., 2011; Theron et al., 2016; Yunker et al., 2018; Thomas et al., 2019) and individual elementary steps associated with catalytic cycles to be defined (Vikse\&McIndoe, 2015). The use of quasi-enantiomeric substrates, in which mass-labeled enantiomeric reactants are encoded to provided different $\mathrm{m} / \mathrm{z}$ values, combined with ESI-MS monitoring have even been used to determine the intrinsic This article is protected by copyright. All rights reserved. 
enantioselectivity of chiral catalysts by monitoring catalytic intermediates (Müller et al., 2009).

Given the numerous MS-based studies on organometallic ion chemistry related to catalysis, the scope of this review is limited to metal-catalyzed transformations of carboxylic acids and their derivatives of relevance to organic synthesis. Fragmentation reactions of coordinated carboxylates that involve redox chemistry and give rise to metal anions (Curtis et al., 2010; Attygalle et al., 2011; Curtis et al., 2011; Butson et al., 2016) or metal- $\mathrm{CO}_{2}$ complexes (Dossmann et al., 2012; Rodriguez-Blanco et al., 2013; Miller et al., 2014; Blaziak et al., 2018; Jestila\&Uggerud, 2018; Miller\&Uggerud, 2018; Jestila et al., 2020), although fascinating in their own right, are not reviewed. Carboxylic acids and their derivatives that contain multiple functional groups (e.g. peptides and proteins) are not considered. Readers interested in studies of other substrates where organometallic intermediates of relevance to catalysis have been examined are directed to a range of reviews (Schröder \& Schwarz, 2008; Schwarz, 2011; Schwarz, 2015B; Schwarz, 2017A; Schwarz et al., 2017B).

\section{B. Fundamental Consideration of the Modes of Reactivity of Carboxylic Acids and Carboxylic acid esters and How to Exploit them in New Metal-Catalyzed Processes.}

Carboxylic acids, $\mathrm{RCO}_{2} \mathrm{H}$, are key players on the stage of organic chemistry (Patai, 1992) and every undergraduate student encounters them in their organic chemistry classes. Most organic chemistry lectures and undergraduate textbooks focus on the synthetic utility of nucleophilic acyl substitution reactions (reaction 1 of Scheme 1) of carboxylic acids and their derivatives, $\mathrm{RCOX}$ (acyl halides, where $\mathrm{X}=$ halide; carboxylic acid esters, where $X=$ OR; amides, where $X=$ NR'R”) (McMurry, 2008).

This article is protected by copyright. All rights reserved. 
This reflects the importance of this class of reaction, which is used by Mother Nature in the biochemistry of proteins and also forms the basis of key steps in a vast number of synthetic endeavours, ranging from small-scale "boutique" synthesis through to the industrial manufacture of important polymers such as nylon and mylar. Other wellknown "textbook" reactions of carboxylic acids are shown in Scheme 1 (McMurry, 2008).

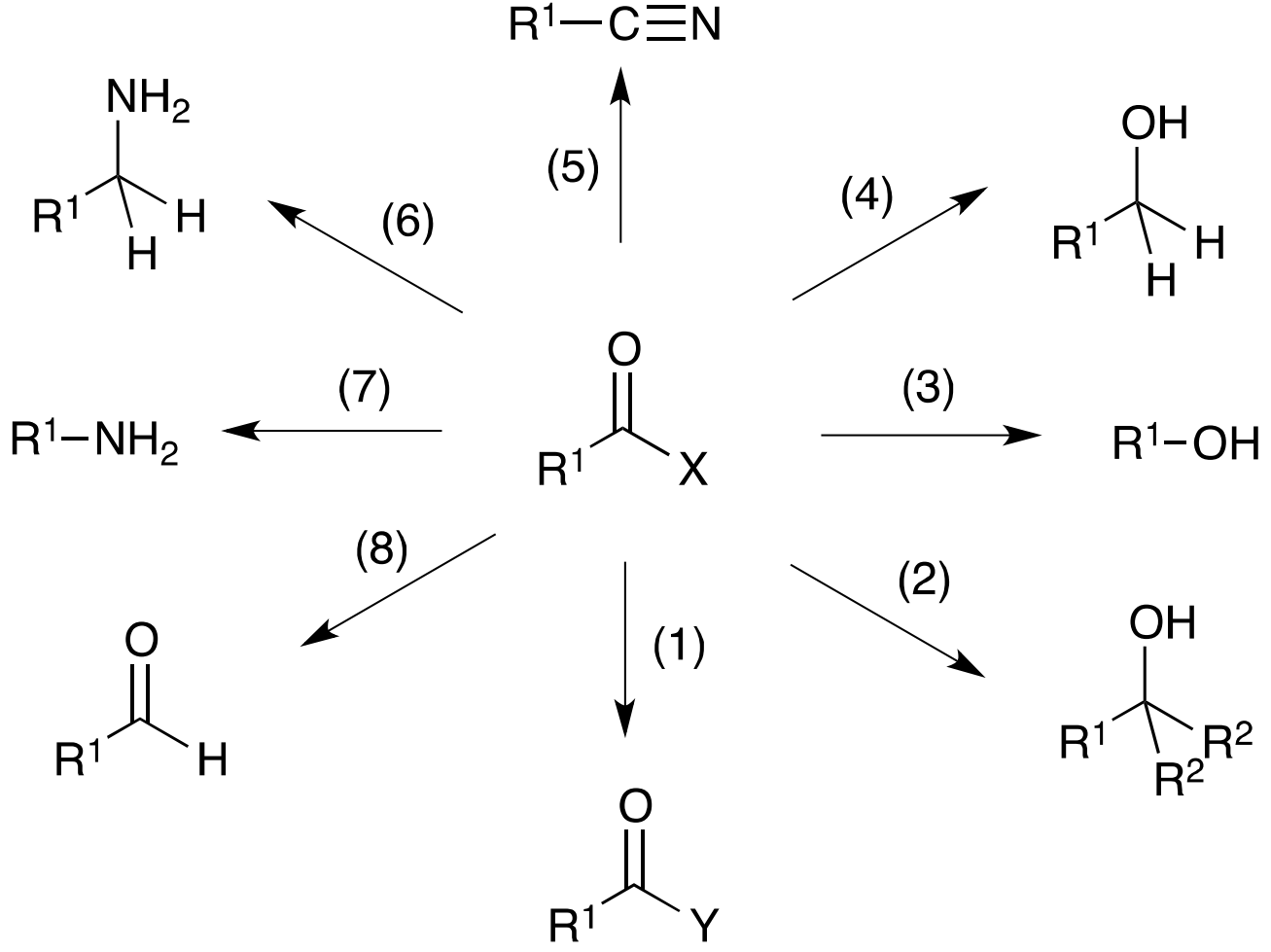

Scheme 1: Some important "textbook" reactions of carboxylic acids and their derivatives. Reaction: (1) nucleophilic acyl substitution; (2) reaction with Grignard reagents to form an alcohol; (3) formation of an alcohol via decarbonylation; (4) reduction to form an alcohol; (5) dehydration of a primary amide $\left(\mathrm{X}=\mathrm{NH}_{2}\right)$ to form a nitrile; (6) reductive amination; (7) formation of an amine via decarbonylation; (8) reduction to form an aldehyde.

Carboxylic acids are attractive substrates since they: (i) exhibit huge structural variety (including stereochemical diversity) due to the wide range of possible R (including alkyl, alkenyl, alkynyl, aryl, heteroaryl, etc); (ii) are widely available from commercial and natural sources; (iii) can often be readily made using well-established procedures

This article is protected by copyright. All rights reserved. 
(e.g. oxidation of primary alcohols or alkylarenes), when not directly available; and (iv) usually exhibit high stability and thus are easy to store and handle.

There has been a renaissance in the exploration of new catalytic transformations of carboxylic acids. Two distinct communities have largely driven the motivation for these studies. Chemical engineers are interested in transforming bio-renewable resources such as long chain fatty acids into biofuels and commodity chemicals (Corma et al., 2007; Gosselink et al., 2013). Synthetic organic chemists are interested in expanding the "synthetic toolbox" used in organic synthesis via the "invention" of new reactions (Goossen Ed., 2013). Catalytic transformations of carboxylic acids have great potential to become eco-friendly "green organic chemistry" (Anastas\&Warner, 1998) alternatives to existing synthetic procedures that often require expensive stoichiometric reagents and are either waste-intensive (Baudoin, 2007) or produce toxic by-products.

Here the following topics are reviewed: (1) protodecarboxylation of carboxylic acids; (2) dehydration of carboxylic acids; (3) decarbonylation of carboxylic acids; (4) role of coordinated carboxylates in $\mathrm{C}-\mathrm{H}$ bond activation; (5) remote functionalization of carboxylic acids and their derivatives; (6) decarboxylative C-C bond coupling of carboxylic acids; (7) decarboxylative $\mathrm{C}-\mathrm{C}$ bond coupling of carboxylic acid esters; (8) the potential role for integrated mechanistic studies to discover new catalysts and invent new reactions. Apart from the last topic, the discussion of all topics share a common structure: that catalytic problem is defined; insights from gas-phase studies are discussed; comparisons with condensed-phase systems are made; and perspectives are summarized.

Topics 1 and 2 are related to each other in that they involve decomposition of a carboxylic acid via either: (i) formation of an alkane (or alkene, alkyne and arene) and

This article is protected by copyright. All rights reserved. 
$\mathrm{CO}_{2}$ (eq. 1); (ii) formation of a ketene and water (eq. 2). In the absence of a metal catalyst, pyrolysis of aliphatic carboxylic acid requires high temperatures (typically $>$ $500{ }^{\circ} \mathrm{C}$ ) and is generally non-selective, producing both sets of products (Smith\&Kelly, 1971; Brown, 1980; Clark et al., 2014).

$\begin{array}{rlll}\mathrm{RCO}_{2} \mathrm{H} & \rightarrow \quad \mathrm{RH}+\mathrm{CO}_{2} \quad(1) \\ & \rightarrow \quad(\mathrm{R}-\mathrm{H}) \mathrm{C}=\mathrm{O} \quad+\quad \mathrm{H}_{2} \mathrm{O}\end{array}$

The transformation of the carboxylic acid or carboxylic acid ester substrate in each of these topics involves reaction at three different sites associated with the activation of different bonds, as shown in Scheme 2.

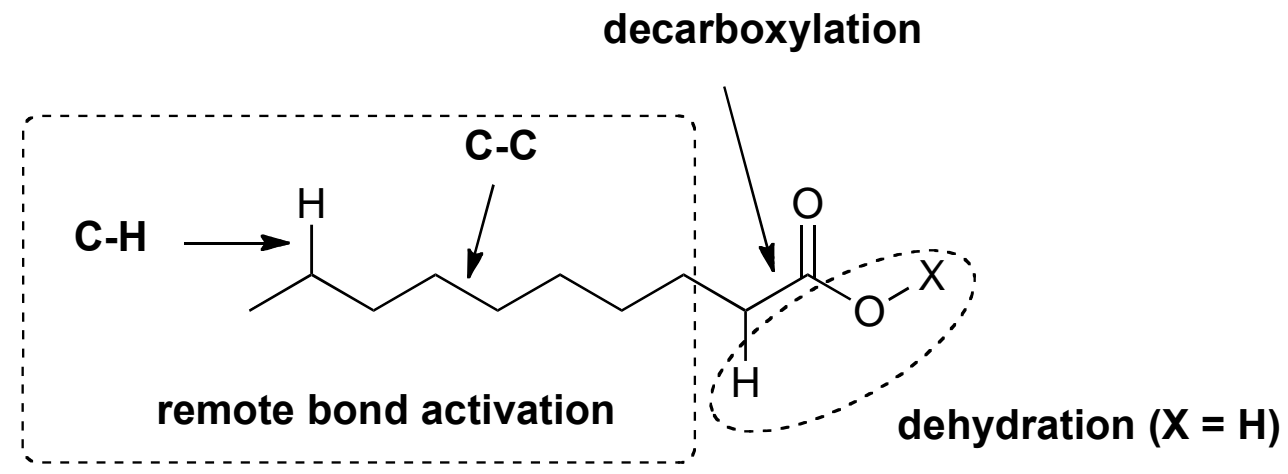

Scheme 2: Sites of reaction for a long chain fatty acid $(X=H)$ or acid ester $(X=$ an alkyl group).

Topics 1, 3, 6 and 7 are related as they involve activation of the $\mathrm{C}-\mathrm{C}(\mathrm{O})$ bond, and proceed via the same key decarboxylation step of a metal acetate to give an organometallic complex (eq. 3 , where $\mathrm{M}=$ metal, $\mathrm{L}=$ auxiliary ligand, and $\mathrm{x}=$ the net charge of the complex). As this topic has been the subject of a review (O'Hair\&Rijs, $2015)$, it is only briefly discussed in section 2 . Topic 2 involves activation of both the $\alpha-\mathrm{C}-\mathrm{H}$ and $\mathrm{C}-\mathrm{OH}$ bond to give a ketene, while topic 5 involves activation of either a $\mathrm{C}$ $\mathrm{H}$ or a $\mathrm{C}-\mathrm{C}$ bond that is remote from the carboxyl group. Topic 4 discussed the role that This article is protected by copyright. All rights reserved. 
coordinated carboxylates can play in promoting $\mathrm{C}-\mathrm{H}$ bond activation of organic substrates.

$$
\left[(\mathrm{L})_{n} \mathrm{M}\left(\mathrm{O}_{2} \mathrm{CR}\right)\right]^{\mathrm{x}} \quad \rightarrow \quad\left[(\mathrm{L})_{n} \mathrm{M}(\mathrm{R})\right]^{\mathrm{x}}+\mathrm{CO}_{2}
$$

Finally, this review does not discuss the operational principles of mass spectrometers. Readers interested in the concept of ion trap mass spectrometers as "complete chemical laboratories" to study catalytic cycles are directed to two previous reviews (O'Hair, 2006; O'Hair\&Rijs, 2015). It is worth noting that a key theme in much of the gas-phase catalytic work using ion trap mass spectrometers is that highly reactive metal species can be "unleashed" by collision induced dissociation (CID) (O'Hair, 2010), and then mass selected for subsequent ion-molecule reactions or additional stages of CID. An important development in gas-phase studies is the coupling of mass spectrometers to tunable lasers, which allows the gas-phase IR or UV-Vis spectra of inorganic and organometallic species to be examined. The gas-phase spectroscopy of organometallic complexes (MacAleese\&Maitre, 2007; Roithová, 2012; Roithová et al., 2016; Jasikova \& Roithová, 2018) or metal carboxylate complexes (Duchackova et al., 2011) are not reviewed here unless they have been used to gain insights into the topics of this review.

\section{Protodecarboxylation of carboxylic acids}

\section{A. Definition of the catalytic problem}

Protodecarboxylation (eq. 1) is one of the simplest and oldest class of metal-catalyzed reactions of carboxylic acids (Shepard et al., 1930). This desirable reaction has been used in organic synthesis to remove a carboxylic acid functional group, including after its directing effect has been exerted (Cornella et al., 2011; Tang et al., 2016; Biafora\&Goossen, 2017) or to regiospecifically introduce a deuterium into an organic

This article is protected by copyright. All rights reserved. 
molecule (Matsubara et al., 2004; Grainger et al., 2012). In contrast, it can be an undesirable reaction in metal-catalyzed cross-coupling reactions since it produces an unwanted side product (Goossen et al., 2010).

\section{B. Insights from gas-phase studies}

The metal-catalyzed protodecarboxylation of acetic acid yields $\mathrm{CO}_{2}$ and $\mathrm{CH}_{4}$ (eq. 1) and has been reported to be catalyzed by the organomagnesates $\left[\mathrm{CH}_{3} \mathrm{MgL}_{2}\right]^{-}(\mathrm{L}=\mathrm{Cl}$ and $\left.=\mathrm{O}_{2} \mathrm{CCH}_{3}\right)\left(\mathrm{O}^{\prime} \mathrm{Hair}\right.$ et al., 2004) as well as Group $10\left[(\text { phen }) \mathrm{M}\left(\mathrm{CH}_{3}\right)\right]^{+}$cations (Woolley, Khairallah et al., 2014). The latter T-shaped three-coordinate 14e-complexes are highly reactive (Ortuno et al., 2013) and can potentially react via two competing cycles (Scheme 3 ). In cycle 1 the organometallic complex is directly protonated in step 1a. Cycle 2 is water-catalyzed in which the organometallic complex is hydrolyzed in step 1b (Woolley et al., 2013), with the resultant hydroxide reacting with acetic acid in step 3. Both cycles share the same decarboxylation step 2a to regenerate the organometallic $\left[(\text { phen }) \mathrm{M}\left(\mathrm{CH}_{3}\right)\right]^{+}$.

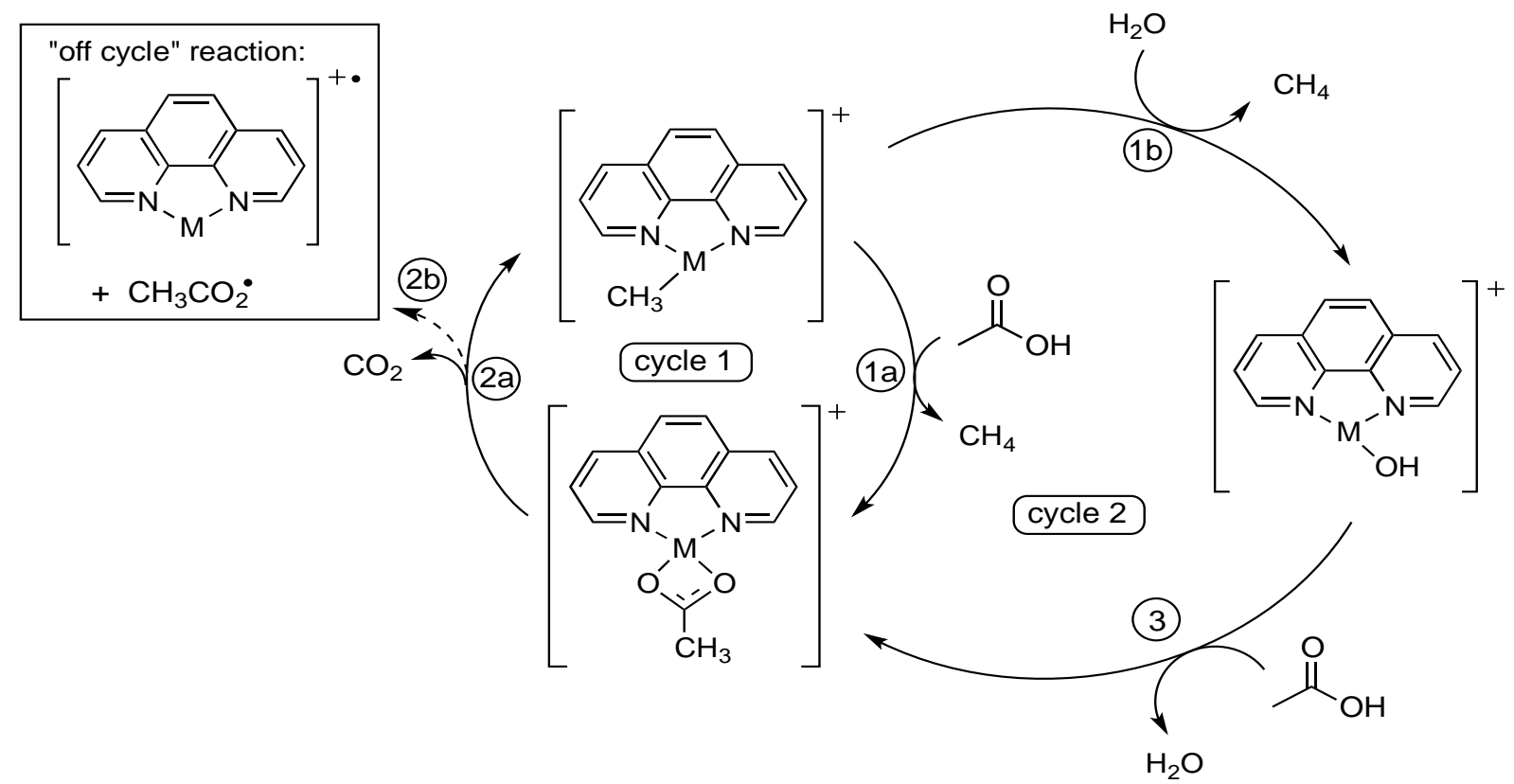

Scheme 3: Competing two-step versus three-step mechanisms for the protodecarboxylation of acetic acid (eq. 9, $\mathrm{R}=\mathrm{CH}_{3}$ ) (Woolley, Khairallah et al., 2014).

This article is protected by copyright. All rights reserved. 
Regardless of the precise mechanisms involved, all metal catalysts that promote protodecarboxylation of carboxylic acids do so in two discreet steps (Figure 1) and so it is informative to compare the DFT calculated energetics of the highest transition state (TS) for each step as a function of the metal catalyst (Table 1).

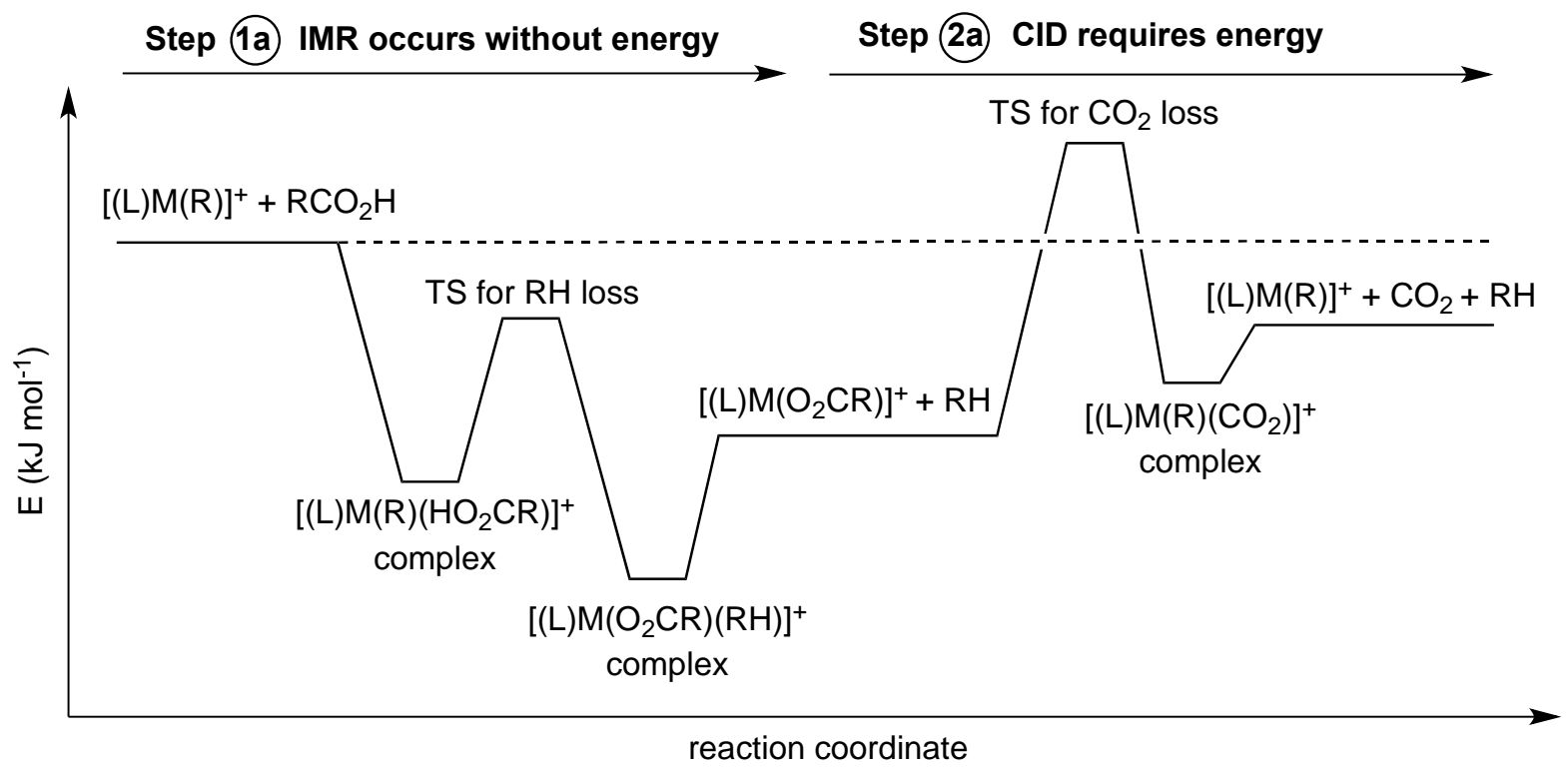

Figure 1: Simplified energy diagram to allow ready comparison of the DFT calculated energetics (Table 1) associated with steps $1 \mathrm{a}$ and $2 \mathrm{a}$ of the metal-catalyzed decomposition of protodecarboxylation of carboxylic acids (Scheme 3).

The gas-phase protonation of the organometallic $[(\mathrm{L}) \mathrm{M}(\mathrm{R})]^{+}$at the $\mathrm{R}$ group by the parent acid, $\mathrm{RCO}_{2} \mathrm{H}$ (Step 1) proceeds via an ion-molecule reaction. The DFT calculations predict that this reaction is exothermic for all organometallic ions (Table 1, column 3) (Woolley, Khairallah et al., 2014). The energy of TS1 should be below that of the separated reactants for this reaction to readily occur under the near thermal conditions of ion-trap mass spectrometers (Woolley, Khairallah et al., 2014), which is the case for $\left[(\text { phen }) \mathrm{Ni}\left(\mathrm{CH}_{3}\right)\right]^{+}$and $\left[(\text {phen }) \mathrm{Pt}\left(\mathrm{CH}_{3}\right)\right]^{+}$but not $\left[(\text {phen }) \mathrm{Pd}\left(\mathrm{CH}_{3}\right)\right]^{+}$(Table 1, column 2).

This article is protected by copyright. All rights reserved. 
Direct reaction of $\left[(\text { phen }) \mathrm{M}\left(\mathrm{CH}_{3}\right)\right]^{+}$with acetic acid, regenerates the $\left[(\text { phen }) \mathrm{M}\left(\mathrm{O}_{2} \mathrm{CCH}_{3}\right)\right]^{+}$catalyst (Cycle 1, Step 2a). Alternatively, hydrolysis may form the hydroxide $[(\text { phen }) \mathrm{M}(\mathrm{OH})]^{+}($Cycle 2 , Step $2 \mathrm{~b})$, which reacts with acetic acid to reform the $\left[(\text { phen }) \mathrm{M}\left(\mathrm{O}_{2} \mathrm{CCH}_{3}\right)\right]^{+}$catalyst and water. Cycle 2 is only competitive for $\mathrm{M}$ $=\mathrm{Ni}$, thereby being the most promising catalyst. A Lewis acid-base mechanism involving a four-centred TS (Figure 2) is favored over ones involving either a sixcentred Lewis acid-base TS or oxidative addition followed by reductive elimination (OA/RE).

Table 1: DFT calculated (MO6/SDD6-31+G(d) level of theory) energetics in kJ mol ${ }^{-1}$ for the gas-phase transition metal-catalyzed protodecarboxylation of acetic acid by $\left[(\text { phen }) \mathrm{M}\left(\mathrm{CH}_{3}\right)\right]^{+}$(Figure 1, eq. 1, $\left.\mathrm{R}=\mathrm{CH}_{3}\right)$. (Woolley, Khairallah et al., 2014)

\begin{tabular}{|l|l|l|l|}
\hline $\begin{array}{l}\text { Organometallic } \\
\text { catalyst }\end{array}$ & $\Delta \mathbf{H}$ TS1 & $\Delta \mathbf{H}$ step1 & $\Delta \mathbf{H ~ T S 2}$ \\
\hline$\left[(\text { phen }) \mathrm{Ni}\left(\mathrm{CH}_{3}\right)\right]^{+}$ & $-29.9^{\text {(a) }}$ & -213.2 & $188.1 ; 181.1^{\text {(b) }}$ \\
\hline$\left[(\text { phen }) \operatorname{Pd}\left(\mathrm{CH}_{3}\right)\right]^{+}$ & $+15.4^{\text {(a) }}$ & -138.0 & $179.5 ; 160.2^{\text {(b) }}$ \\
\hline$\left[(\text { phen }) \operatorname{Pt}\left(\mathrm{CH}_{3}\right)\right]^{+}$ & $-9.6^{\text {(a) }}$ & -167.9 & $178.5 ; 170.8^{\text {(b) }}$ \\
\hline
\end{tabular}

(a) Only the lowest energy mechanism, involving the four centred acid-base TS is given as $\Delta \mathrm{H}$ TS1 for Step 1.

(b) Decarboxylation involves two transition states. The energy of the highest TS involving isomerization of binding from bidentate acetate to monodentate acetate is given first followed by the decarboxylation TS energy.

This article is protected by copyright. All rights reserved. 
(a)

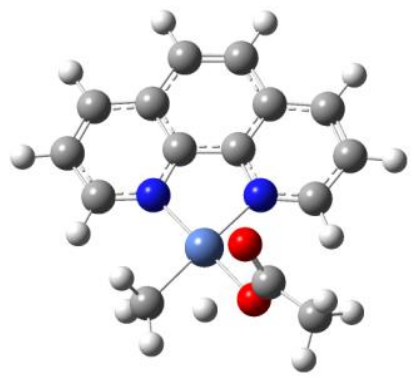

TS $\left[\text { (phen) } \mathrm{Ni}\left(\mathrm{CH}_{3}\right)\left(\mathrm{HO}_{2} \mathrm{CCH}_{3}\right)\right]^{+}$ freq: $-836 \mathrm{~cm}^{-1}$ $E=-29.9 \mathrm{~kJ} \mathrm{~mol}^{-1}$

(d)

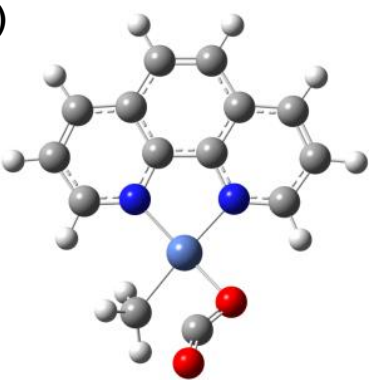

TS [(phen) $\left.) \mathrm{Ni}\left(\mathrm{O}_{2} \mathrm{CCH}_{3}\right)\right]^{+}$

freq: $-337 \mathrm{~cm}^{-1}$

$E=+181.4 \mathrm{~kJ} \mathrm{~mol}^{-1}$ (b)

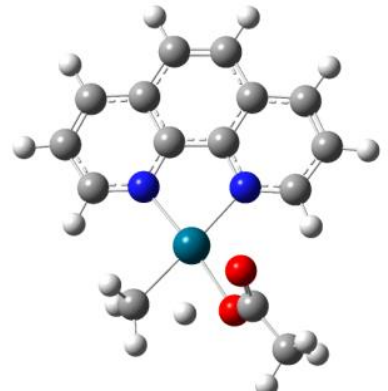

TS $\left[(\text { phen }) \mathrm{Pd}\left(\mathrm{CH}_{3}\right)\left(\mathrm{HO}_{2} \mathrm{CCH}_{3}\right)\right]^{+}$ freq: $-1324 \mathrm{~cm}^{-1}$

$E=+15.5 \mathrm{~kJ} \mathrm{~mol}^{-1}$

(e)

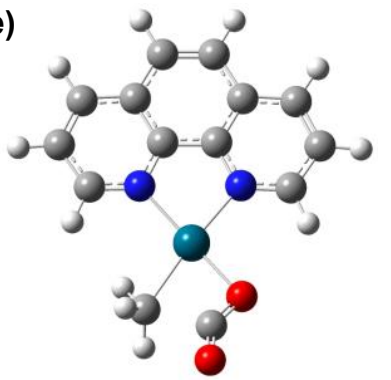

TS [(phen) $\left.\mathrm{Pd}\left(\mathrm{O}_{2} \mathrm{CCH}_{3}\right)\right]^{+}$

freq: $-418 \mathrm{~cm}^{-1}$

$E=+160.2 \mathrm{~kJ} \mathrm{~mol}^{-1}$ (c)

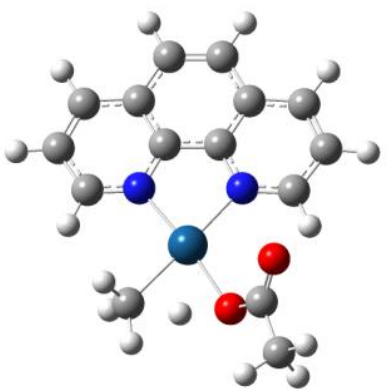

TS $\left[(\text { phen }) \mathrm{Pt}\left(\mathrm{CH}_{3}\right)\left(\mathrm{HO}_{2} \mathrm{CCH}_{3}\right)\right]^{+}$ freq: $-1355 \mathrm{~cm}^{-1}$ $E=-9.6 \mathrm{~kJ} \mathrm{~mol}^{-1}$

(f)

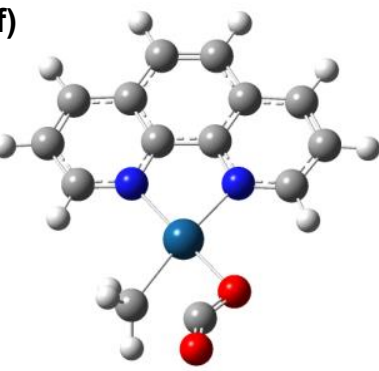

TS $\left[(\text { phen }) \mathrm{Pt}\left(\mathrm{O}_{2} \mathrm{CCH}_{3}\right)\right]^{+}$ freq: $-441 \mathrm{~cm}^{-1}$ $E=+170.8 \mathrm{~kJ} \mathrm{~mol}^{-1}$

Figure 2: DFT calculated four-centred transition states for the: reaction of [(phen) $\left.\mathrm{M}\left(\mathrm{CH}_{3}\right)\right]^{+}$with acetic acid (Scheme 3, step 1): (a) $\mathrm{M}=\mathrm{Ni}$; (b) $\mathrm{M}=\mathrm{Pd}$; (c) $\mathrm{M}=$ $\mathrm{Pt}$; decarboxylation of $\left[(\text { phen }) \mathrm{M}\left(\mathrm{O}_{2} \mathrm{CCH}_{3}\right)\right]^{+}$(Scheme 3, step 2): (d) $\mathrm{M}=\mathrm{Ni}$; (e) $\mathrm{M}=$ $\mathrm{Pd}$; (f) $\mathrm{M}=\mathrm{Pt}$.

The metal carboxylate cationic or anionic products of protodecarboxylation, $\left[(\mathrm{L}) \mathrm{M}\left(\mathrm{O}_{2} \mathrm{CR}\right)\right]^{+/}$, are cooled back to room temperature via collisions with the helium bath gas (Gronert, 1998; Donald et al., 2013). In order to be decarboxylated, it must be mass selected and allowed to undergo an endothermic CID reaction in step 2a. The decomposition of charged metal carboxylate complexes, $\left[(\mathrm{L}) \mathrm{M}\left(\mathrm{O}_{2} \mathrm{CR}\right)\right]^{+/-}$, is influenced by the R group, metal center, cluster nuclearity, and auxiliary ligand(s), L. In many cases other fragmentation pathways can be in competition with the desired decarboxylation reaction. Since these factors have been discussed for a wide range of metal complexes (O'Hair\&Rijs, 2015), here I will focus on the metal complexes that have been shown to catalyze the decarboxylation of acetic acid in the gas phase.

This article is protected by copyright. All rights reserved. 


\section{Decarboxylation of $\left[(\mathrm{L})_{2} \mathrm{Mg}\left(\mathrm{O}_{2} \mathrm{CCH}_{3}\right)\right]^{-}\left(\mathrm{L}=\mathrm{Cl}\right.$ and $\left.=\mathrm{O}_{2} \mathrm{CCH}_{3}\right)$.}

The auxiliary ligands play a key role in tuning the activation energy for decarboxylation (O'Hair et al., 2004). Energy-resolved CID experiments on the ions [(L) $\left.{ }_{2} \mathrm{Mg}\left(\mathrm{CH}_{3}\right)\right]^{-}$ reveal that there is a lower threshold for $\mathrm{CO}_{2}$ loss in the case of $\mathrm{L}=\mathrm{Cl}$. DFT calculations reveal that the auxiliary ligand influences the geometry of the four-centred decarboxylation TS in these organomagnesates. In the case of $\left[\mathrm{Cl}_{2} \mathrm{Mg}\left(\mathrm{CH}_{3}\right)\right]^{-}$, the two $\mathrm{Cl}$ ligands make this TS quasi four- coordinated. In contrast, in the case of $\left[\left(\mathrm{CH}_{3} \mathrm{CO}_{2}\right)_{2} \mathrm{Mg}\left(\mathrm{CH}_{3}\right)\right]^{-}$, one acetate binds in a bidentate mode, making the TS quasi five-coordinated. The crowding of the coordination sphere thus raises the energy of this TS.

\section{Decarboxylation of group 10 acetate complexes, $\left[(\mathrm{L}) \mathrm{Pd}\left(\mathrm{O}_{2} \mathrm{CCH}_{3}\right)\right]^{+}$.}

Once again, the ligand is critical in directing fragmentation to the decarboxylation channel. For example, for $\left[(\mathrm{L}) \mathrm{Pd}\left(\mathrm{O}_{2} \mathrm{CCH}_{3}\right)\right]^{+}$complexes, $\mathrm{C}-\mathrm{H}$ bond activation of the ligand (eq. 4) can compete with the desired decarboxylation reaction (eq. 3). Thus the sole CID fragmentation reaction of $\left[\left(\mathrm{Ph}_{3} \mathrm{P}\right)_{2} \mathrm{Pd}\left(\mathrm{O}_{2} \mathrm{CCH}_{3}\right)\right]^{+}$, which involves loss of acetic acid (eq. 4) (Qian et al., 2006), has been proposed to have the cyclometallated structure 1. Loss of an acetate radical competes (eq. 5) with decarboxylation for the bpy complexes, [(bpy)Pd( $\left.\left(\mathrm{O}_{2} \mathrm{CCH}_{3}\right)\right]^{+}($Butschke\&Schwarz, 2010).

$\left[(\mathrm{L}) \mathrm{M}\left(\mathrm{O}_{2} \mathrm{CCH}_{3}\right)\right]^{+} \quad \rightarrow \quad\left[[(\mathrm{L}-\mathrm{H}) \mathrm{M}]^{+}+\mathrm{CH}_{3} \mathrm{CO}_{2} \mathrm{H}\right.$

$$
\rightarrow \quad\left[[(\mathrm{L}) \mathrm{M}]^{+\cdot}+\mathrm{CH}_{3} \mathrm{CO}_{2}\right.
$$

This article is protected by copyright. All rights reserved. 


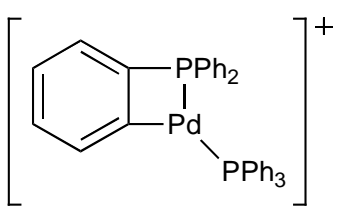

1

As a consequence of these competing fragmentation reactions, we turned our attention to complexes involving the rigid phenanthroline ligand, which cannot undergo "roll over" cyclometallation (Butschke\&Schwarz, 2012). Experimentally, the ease of decarboxylation of $\left[(\text { phen }) \mathrm{M}\left(\mathrm{O}_{2} \mathrm{CCH}_{3}\right)\right]^{+}$to form $\left[(\text {phen }) \mathrm{M}\left(\mathrm{CH}_{3}\right)\right]^{+}$(Step 2a of both cycles, Scheme 3), follows the order $\mathrm{Pd}>\mathrm{Pt}>\mathrm{Ni}$. In the case of $\mathrm{Pd}$ and $\mathrm{Ni}$, a small amount of the "off-cycle" loss of acetate observed (step 2b, Scheme 3). DFT calculations on the decarboxylation of the group 10 acetates, $\left[(\text { phen }) \mathrm{M}\left(\mathrm{O}_{2} \mathrm{CCH}_{3}\right)\right]^{+}$, highlights that this process is a two-step reaction. The first step involves a change in the conformation of the coordinated acetate ligand from bidentate to monodentate. The second step involves a four-centered TS (Figures 2D-F) which produced a fourcoordinated intermediate in which the $\mathrm{CO}_{2}$ is $\mathrm{O}$-coordinated to the metal centre. Liberation of $\mathrm{CO}_{2}$ from this complex, reforms the $\mathrm{T}$-shaped three-coordinated organometallic complex, $\left[(\text { phen }) \mathrm{M}\left(\mathrm{CH}_{3}\right)\right]^{+}$.

\section{Comparisons with condensed-phase systems}

Condensed-phase protodecarboxylation studies have focussed on aromatic carboxylic acids (Shepard et al., 1930; Goossen et al., 2007; Goossen et al., 2009) and 2-alkynoic acids (Kolarovic\&Faberova, 2009; Park\&Lee, 2013) using salts of transition metals such as copper (Scheme 4a-c) (Shepard et al., 1930; Goossen et al., 2007; Goossen et al., 2009), silver (Scheme 4d) (Goossen, Linder et al., 2009; Cornella et al., 2009; Lu et al., 2009; Goossen et al., 2010; Xue et al., 2011; Grainger et al., 2014), gold (Scheme 4e) (Cornella et al., 2011; Dupuy\&Nolan, 2013; Dupuy et al., 2015), and palladium This article is protected by copyright. All rights reserved. 
(Scheme 4f) (Dickstein et al., 2007; Nunez Magro et al., 2009; Dickstein et al., 2013). Most of these studies have involved homogeneous catalysis, although there has been a report on the development of a heterogeneous supported-silver catalyst (Toy et al., 2014). In a number of cases, DFT calculations have been used to shed insights into the steps associated with these protodecarboxylation reactions (Goossen\&Rodriguez et al., 2010; Xue et al., 2011). While it is not possible to make a direct comparison between the protodecarboxylation reactions of group 10 carboxylate complexes that we have studied in the gas phase (Woolley et al., 2013; Woolley et al., 2014) and related systems in the condensed phase, for the second decarboxylation step, DFT calculations highlight that a difference between the gas phase and solution is that in solution coordinating ligands and/or solvent molecules need to be considered, and that part of the energy cost for decarboxylation maybe due to the energy required to lose the coordinated ligand/solvent molecule to free up a vacant coordination site for decarboxylation (Zhang et al., 2010; Dickstein et al., 2013; Rydfjord et al., 2013). In the gas phase, these coordinating ligands and/or solvent molecules are generally missing.

This article is protected by copyright. All rights reserved. 
(A)

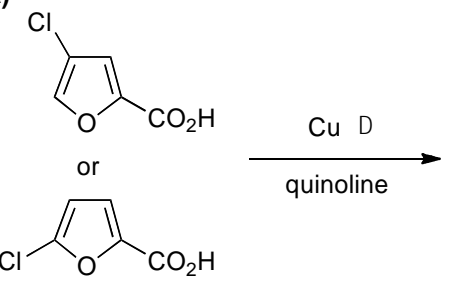

Shepard, Winslow and Johnson 1930

(B)

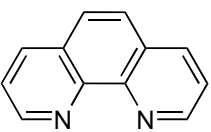

$\underbrace{C_{Y}^{11}}_{Y} \mathrm{CO}_{2} \mathrm{H}$

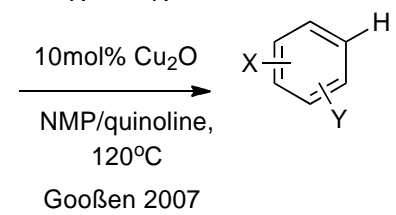

(C)

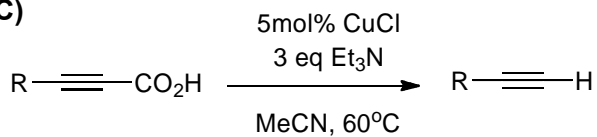

Kolarovic and Fáberová 2009
(D)<smiles>[Y]c1ccc(C(=O)[O-])cc1</smiles>

or<smiles>O=C(O)C=Cc1ccccc1</smiles>

Solvent $=$ NMP Gooßen 2009

Solvent $=$ DMSO Larossa 2009

(E)<smiles>[Y]c1ccc(C(=O)O)cc1</smiles>

$2 \mathrm{~mol} \%$

$\underset{\text { toluene, } 120^{\circ} \mathrm{C}}{\stackrel{[\mathrm{Au}(\mathrm{SIPr})(\mathrm{OH})]}{\mathrm{RCO}_{2} \mathrm{H}}}$

Nolan 2013

(F)

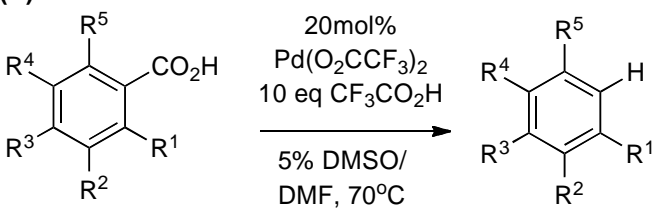

Kozlowski 2007

Scheme 4: Examples of metal catalysts that have been developed for protodecarboxylation reactions in solution: (a) - (c) copper catalysts; (d) silver catalyst; (e) gold catalyst, where $\mathrm{SIPr}=1,3$-bis(2,6-diisopropylphenyl)-4,5- dihydroimidazolin2-ylidene; (f) platinum catalyst.

\section{Perspectives}

The gas-phase studies of protodecarboxylation reactions have revealed that a range of other metal complexes is capable of catalyzing these reactions. This is consistent with other recent solution-phase studies, which have extended Shepard, Winslow and Johnson's copper quinolone catalytic system (Scheme 4a) to other copper catalysts (Scheme 4b,c) silver catalysts (Scheme 4d), gold catalysts (Scheme 4e) and platinum catalysts (Scheme 4f). Our observation that the nickel-phenanthroline complex catalyzes protodecarboxylation suggests that nickel complexes are worth examining as catalysts for protodecarboxylation in solution.

This article is protected by copyright. All rights reserved. 


\section{Dehydration of carboxylic acids}

\section{A. Definition of the catalytic problem}

Ketenes are important reactive intermediates (Allen\&Tidwell, 2013; Allen\&Tidwell, 2016) that are used as feedstock for the production of acetic anhydride as well as in a range of synthetic protocols in organic synthesis (Tidwell, 1995), including the synthesis of polymers (Leibfarth\&Hawker, 2013). Although there are a number of ways of synthesising ketenes (Tidwell, 1995), the selective dehydration of carboxylic acids is an attractive route due to their ready availability and the fact that water is the sole byproduct. Thus there has been considerable interest in devising metal oxide catalysts to lower the activation energy for dehydration and thereby improve the selectivity for ketene formation (Libby et al., 1994; Barteau, 1996; Kulik, 2012).

\section{B. Insights from gas-phase studies}

The dehydration of acetic acid to ketene (eq. 2, $\mathrm{R}=\mathrm{CH}_{3}$ ) is catalyzed by Group 6 mononuclear $\left[\mathrm{MO}_{3}(\mathrm{OH})\right]^{-}$and binuclear $\left[\mathrm{M}_{2} \mathrm{O}_{6}(\mathrm{OH})\right]^{-}$oxo-anions $(\mathrm{M}=\mathrm{Mo}, \mathrm{W})$ (Waters et al., 2003A). In contrast to the three-step oxidation of methanol (Waters et al., 2000; Waters et al., 2003B), the catalytic dehydration of acetic acid is less sensitive towards the structure of the catalyst, working for both molybdenum and tungsten mononuclear and binuclear anions. Step 1 is a metathesis step in which the $\mathrm{OH}$ ligand is switched for a carboxylato ligand (Scheme 5). The second step is the rate-determining step, as it requires activation (under CID conditions) to induce dehydration to reform the oxo-anion catalyst. Although DFT calculations have not been carried out on these dehydration reactions, they are expected to have a similar energy profile to that shown in Figure 1. Finally, the nature of both the carboxylic acid as well as the metal oxide

This article is protected by copyright. All rights reserved. 
anion dictate whether the catalytic cycle shown in Scheme 5 operates. When trifluoroacetic acid is used, the binuclear molybdate anion, $\left[\mathrm{Mo}_{2} \mathrm{O}_{6}(\mathrm{OH})\right]^{-}$, does react via step 1, but upon CID the resultant product, $\left[\mathrm{Mo}_{2} \mathrm{O}_{6}\left(\mathrm{O}_{2} \mathrm{CCF}_{3}\right)\right]^{-}$, undergoes $\mathrm{C}$-F bond activation instead to form $\left[\mathrm{Mo}_{2} \mathrm{O}_{6}(\mathrm{~F})\right]^{-}$(Khairallah et al., 2018). The rhenium oxide anions, $\left[\mathrm{ReO}_{\mathrm{x}}\right]^{-}$, react via quite different pathways with acetic acid: for those in higher oxidation states $(x=3$ and 4$)$ no reaction was observed, whereas $\left[\mathrm{ReO}_{2}\right]^{-}$promotes a complex series of C-X bond activation reactions (Canale et al., 2015).

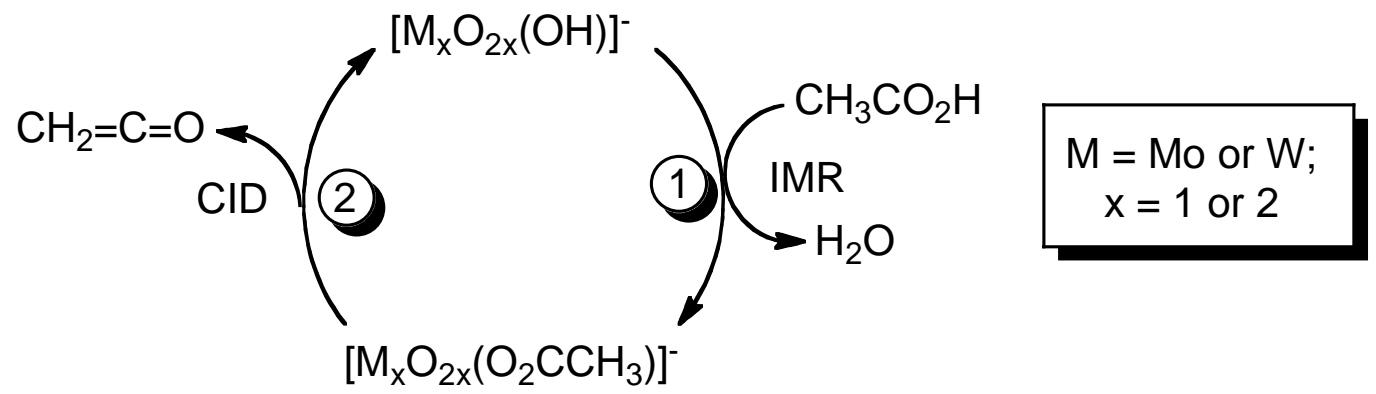

Scheme 5: Two-step dehydration of acetic acid (eq. 2, $\mathrm{R}=\mathrm{CH}_{3}$ ) catalyzed by group 6 mononuclear $\left[\mathrm{MO}_{3}(\mathrm{OH})\right]^{-}$and binuclear $\left[\mathrm{M}_{2} \mathrm{O}_{6}(\mathrm{OH})\right]^{-}$oxo-anions (Waters et al., 2003A).

\section{Comparisons with condensed-phase systems}

There are a number of similarities to the catalytic cycle shown in Scheme 5 and previous reports on the preparation of ketenes via catalytic dehydration of carboxylic acids over silica, metal or metal-oxide surfaces (Libby et al., 1994; Barteau, 1996; Kulik, 2012). These heterogeneous reactions occur at the interface between the gas phase and surfaces and are proposed to involve a three-step processes (Scheme 6): (i) initial physical absorption of the acetic acid molecule onto the surface to the surface hydroxyl site; (ii) formation of a surface carboxylate via elimination of water; (iii) decomposition of the surface carboxylate at high temperature to induce ketene loss with regeneration of the surface hydroxyl site.

This article is protected by copyright. All rights reserved. 


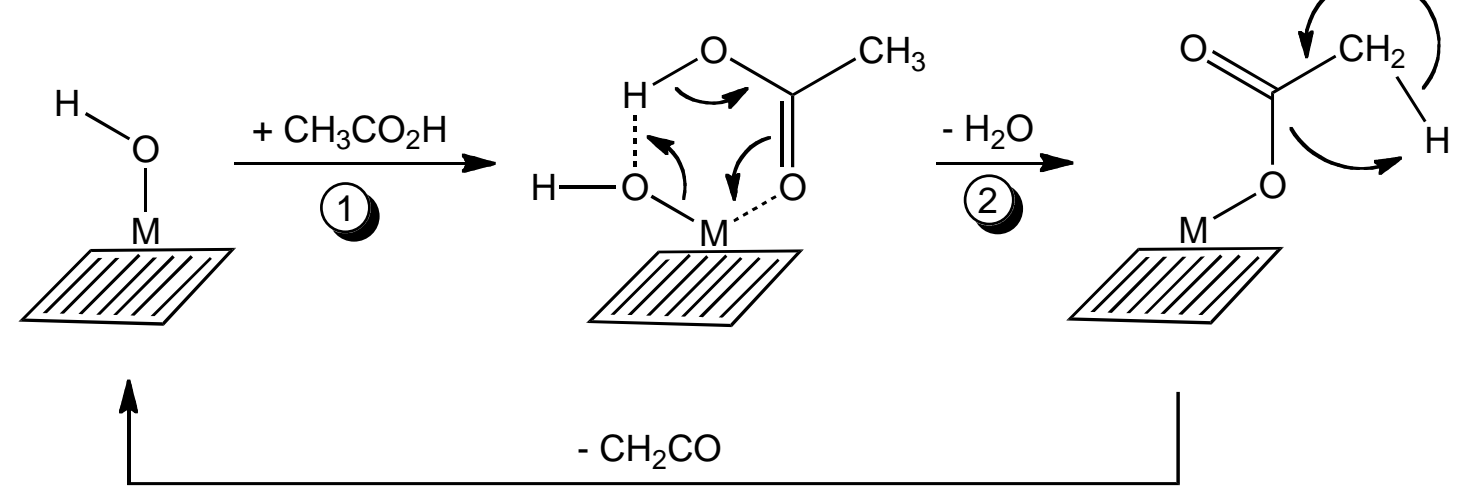

(3)

Scheme 6: Proposed mechanism for catalytic dehydration of carboxylic acids over metal oxide surfaces occurring at metal hydroxide sites, adapted from (Libby et al., 1994; Barteau, 1996; Kulik, 2012).

\section{Perspectives}

As Barteau has noted, "the menu of possible reactions for adsorbed acetic acid on metal oxides has been well documented" (Martinez et al., 2004). It includes: decarboxylation, which produces $\mathrm{CO}_{2}$ (eq. 1); dehydration, which yields ketene (eq. 2); reduction, which produces acetaldehyde; and ketonization, which formally involves the reaction of two equivalents of acetic acid leading to the production of acetone (eq. 6). The selectivity of these reaction channels depends strongly on the nature of the metal oxide surface, reflecting the intrinsic chemistry of the various catalysts. Developing a better understanding of the relationship between surface structure and selectivity is an area ripe for exploration using DFT calculations (Ebrahimi et al., 2009; Ignatchenko, 2011; Lu et al., 2012). Indeed, due to the significant interest of the chemical engineering community in upgrading carboxylic acids from biomass sources, the surface chemistry of ketonization (eq. 6) has been the subject of several recent theoretical studies (Pham et al., 2013; Pulido et al., 2013; Pacchioni, 2014).

$2 \mathrm{CH}_{3} \mathrm{CO}_{2} \mathrm{H} \rightarrow\left(\mathrm{CH}_{3}\right)_{2} \mathrm{CO}+\mathrm{CO}_{2}+\mathrm{H}_{2} \mathrm{O}$

This article is protected by copyright. All rights reserved. 


\section{Decarbonylation of carboxylic acids}

\section{A. Definition of the catalytic problem}

The potential of metal-catalyzed decarbonylation of carboxylic acid derivatives for organic synthesis has attracted considerable renewed interest over the past decade as highlighted in several reviews (Dzik et al., 2012; Dermenci\&Dong, 2013; Takise et al., 2017; Guo\& Rueping, 2018A\&B; Wang et al., 2020). Some representative transformations are shown in Scheme 7. Typically these reactions occur under homogenous catalytic conditions and involve the activation of the $\mathrm{C}_{\text {aryl- }} \mathrm{C}$ bond of aryl carboxylic acid esters, amides, halides or anhydrides via insertion of a transition metal complex (reaction 9) to give an aroylorganometallic intermediate, $\mathbf{2}$, that then undergoes decarbonylation (reaction 10) to given an organometallic intermediate, 3. The latter can then react with organic substrates via C-H (reaction 11), C-C (reactions 12 - 15) and $\mathrm{C}-\mathrm{X}$ bond (reaction 16) forming reactions to produce a range of compounds.

This article is protected by copyright. All rights reserved. 
<smiles>[X]C(=O)[Al]</smiles>

(9)<smiles>c1ccccc1</smiles><smiles>[X]c1ccc(C(=O)[Al])cc1</smiles>

2 (where $\mathrm{Y}=\mathrm{NH}_{2}, \mathrm{OR}$, SR, $\mathrm{PR}_{2}, \mathrm{~B}(\mathrm{OR})_{2}, \mathrm{SiR}_{3}, \mathrm{SnR}_{3}$ )

$\mathrm{Ar}-\mathrm{Y}$
(16)

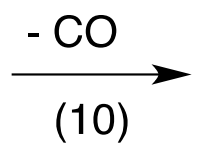
(11)<smiles>[X]c1ccc([Al])cc1</smiles>

3

(12)

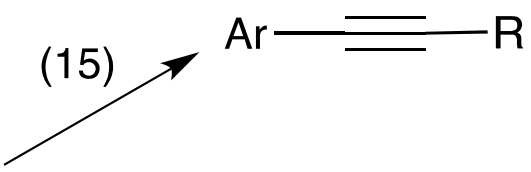

(14) $\mathrm{Ar}-\mathrm{CN}$

(13)

$\mathrm{Ar}-\mathrm{Ar}^{\prime}$<smiles>[R7]C=C[AlH2]</smiles>

Scheme 7: Metal-mediated decarbonylation of carboxylic acid derivatives for organic synthesis. Reaction: (9) insertion; (10) decarbonylation; (11) protonation; (12) Hecklike reaction; (13) biaryl coupling; (14) nitrile formation; (15) Sonogashira-like coupling; (16) heteratom coupling.

Other important applications are the transformation of biomass-derived feedstocks under heterogenous catalytic conditions. For example, "renewable diesel', (Knothe, 2010) can be produced from the fat or oil derived from triacylglycerols by a hydrodeoxygenation reaction at elevated temperature and pressure in the presence of a catalyst (Helwani et al., 2009; Zhao et al., 2013). Many other types of molecules found in biomass require metal-catalyzed defunctionalisation for the production of commodity chemicals (Dawes et al., 2015). Since many biomass-derived molecules contain carboxylic acid functional groups, metal-catalyzed decarbonylation and decarboxylation reactions are important (Santillan-Jimenez\&Crocker, 2012; Dawes et al., 2015). While many of the reaction pathways associated with the transformations of

This article is protected by copyright. All rights reserved. 
these complex mixtures have been defined (Gosselink et al., 2013), the mechanistic features for each key step are not well understood.

\section{B. Insights from gas-phase studies}

The decarbonylation of coordinated acetate ligands in $\left[\mathrm{CH}_{3} \mathrm{CO}_{2} \mathrm{Pd}\left(\left(\mathrm{PR}_{2}\right)_{2} \mathrm{CH}_{2}\right)\right]^{+}$ complexes (Scheme 8, where $\mathrm{R}=\mathrm{Ph}, \mathbf{1 a}$, and $\mathrm{R}=\mathrm{Me}, \mathbf{1 b}$ ) has been reported (Lesslie et al., 2018). CID of the labelled acetate complexes $\left[\mathrm{CH}_{3}{ }^{13} \mathrm{CO}_{2} \mathrm{Pd}\left(\left(\mathrm{PR}_{2}\right)_{2} \mathrm{CH}_{2}\right)\right]^{+}$and $\left[\mathrm{CD}_{3} \mathrm{CO}_{2} \mathrm{Pd}\left(\left(\mathrm{PR}_{2}\right)_{2} \mathrm{CH}_{2}\right)\right]^{+}$confirmed loss of $\mathrm{CO}$ occurred. Gas-phase IR experiments identified the decarbonylation product as $\left[\mathrm{CH}_{3} \mathrm{Pd}\left(\mathrm{OP}\left(\mathrm{Ph}_{2}\right) \mathrm{CH}_{2} \mathrm{PPh}_{2}\right]^{+}, \mathbf{3}\right.$, highlighting that that the bisphosphine ligand facilitates decarbonylation of the coordinated acetate ligand. DFT calculations uncovered a plausible mechanism involving $\mathrm{O}$ atom abstraction by the diphosphine ligand within the coordination sphere to yield the acetyl complex, $\left[\mathrm{CH}_{3} \mathrm{C}(\mathrm{O}) \mathrm{Pd}\left(\mathrm{OP}\left(\mathrm{Ph}_{2}\right) \mathrm{CH}_{2} \mathrm{PPh}_{2}\right]^{+}\right.$, 2, which then undergoes decarbonylation. In contrast, decarboxylation of 1 to form $\left[\mathrm{CH}_{3} \mathrm{Pd}\left(\left(\mathrm{PR}_{2}\right)_{2} \mathrm{CH}_{2}\right)\right]^{+}, \mathbf{4}$, was found to be a minor channel experimentally, consistent with a higher DFT calculated barrier for $\mathrm{CO}_{2}$ loss compared to the decarbonylation channel.
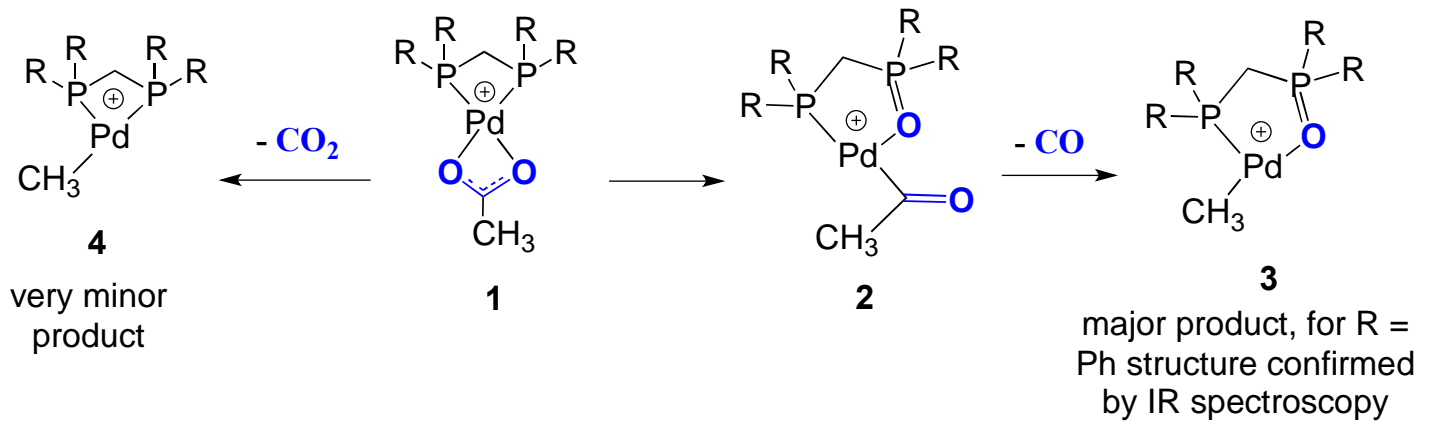

Scheme 8: Ligand-facilitated decarbonylation of a coordinated acetate ligand.

This article is protected by copyright. All rights reserved. 


\section{Comparisons with condensed-phase systems}

Although there is a vast literature on metal-catalyzed deoxygenation of carboxylic acids and their derivatives, most procedures require the addition of activating anhydride reagents to form mixed anhydrides, which then undergo insertion (Scheme 7, where X $=$ carboxylate) (John et al., 2016; Ortuño et al., 2016; Zhang et al., 2018). Fewer studies have described the direct decarbonylation of a carboxylic acid (Fenton, 1970; Foglia\&Barr, 1976), and although it has typically been assumed that they proceed via the coordinated carboxylate (Prince\&Raspin, 1966), there has not been any evidence for the mechanism(s) associated with this process. The discovery that triphenyl phosphine can be used as a stoichiometric reductant (John et al., 2017) suggests it may play a similar role to the bisphosphine ligand where one of the $\mathrm{P}$ atoms attacks one of the coordinated $\mathrm{O}$ atoms of the carboxylate in $\mathbf{1}$ to form the coordinated acyl intermediate 2 in Scheme 8.

\section{Perspectives}

The development of catalytic $\mathrm{C}-\mathrm{C}(\mathrm{O})$ bond cleavage reactions of carboxylic acids and their derivatives for use in the production of fine and commodity chemical continues. A key goal is to develop methods where stoichiometric additives are not required. An exciting recent development is the selective conversion of fatty acids into to alphaolefins (Scheme 9) through the use of a dual-catalyst system consisting of a cobalt catalyst, which functions as a proton-reduction catalyst together with a photoredox catalyst, which facilitates oxidative decarboxylation (Sun et al., 2018).

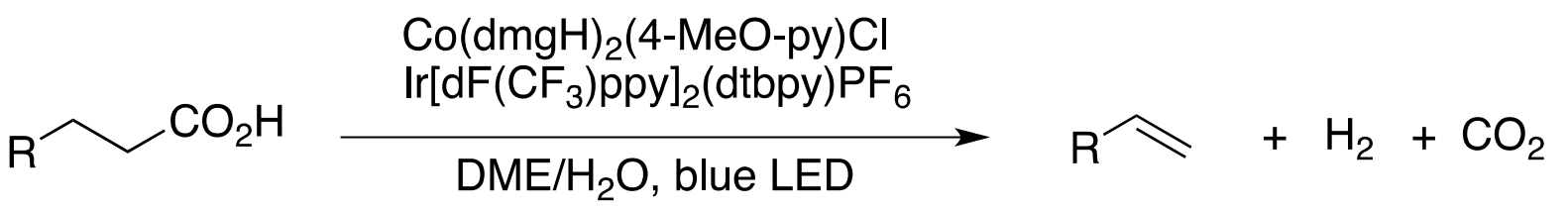

This article is protected by copyright. All rights reserved. 
Scheme 9: New dual metal photocatalysis approach for the selective conversion of fatty acids into to alpha-olefins (Sun et al., 2018). Abbreviations: $\mathrm{dmg}=$ dimethylglyoximate; 4-MeO-py = 4-methoxypyridine; $\mathrm{dF}(\mathrm{CF} 3)$ ppy $=2-(2,4-$ difluorophenyl)-5-(trifluoromethyl)pyridine and dtbpy $=4,4$ '-di-tert-butyl-2,2'bipyridine; $\mathrm{DME}=$ dimethoxyethane; LED = light-emitting diode.

\section{Reactions of coordinated carboxylates as intramolecular bases in $\mathrm{C}-\mathrm{H}$ bond activation}

\section{A. Definition of the catalytic problem}

Synthetic methods that harness transition metal-catalyzed $\mathrm{C}-\mathrm{H}$ bond functionalization continue to attract intense interest (Lyons\&Sanford, 2010; Hummel et al., 2017). The functionalization of a C-H bond is challenging and often a directing group (DG) (Sambiagio et al., 2018) is used to control the regioselectivity of the reaction via formation of a cyclometallated intermediate (Albrecht, 2010). Although the mechanistic aspects are often not well understood, in many instances carboxylates are thought to play a key role in promoting the C-H bond activation step (Ackermann, 2011, Carrow et al., 2020). For example, the acetate ligand in Pd(II) cationic complexes can act as an intramolecular base to promote $\mathrm{C}-\mathrm{H}$ bond activation. This mode of reactivity has been widely exploited in the condensed phase to generate organometallic precursors for use in organic synthesis. Although mass spectrometry has recently been deployed as an analytical technique to identify side products and optimise reaction conditions for the $\mathrm{Ru}(\mathrm{II})$-catalyzed amidation of 2-arylpyridines with aryl isocyanates via $\mathrm{C}-\mathrm{H}$ bond activation (McKay et al., 2020), there are few reports where MS-based methods have been used to provide mechanistic insight into the $\mathrm{C}-\mathrm{H}$ bond activation by a coordinated carboxylate.

This article is protected by copyright. All rights reserved. 


\section{B. Insights from gas-phase studies}

In a key paper, the $\mathrm{C}-\mathrm{H}$ activation of 2-phenylpyridine within the coordination sphere of copper(II), palladium(II) and ruthenium(II) carboxylate complex cations was studied in the gas phase (Scheme 10) (Gray et al., 2015). ESI was used to generate the complexes $\left[(2-\mathrm{PhPy}) \mathrm{M}\left(\mathrm{O}_{2} \mathrm{CR}\right)(\mathrm{L})\right]^{+}, \mathbf{8}$, and energy-resolved CID was used to estimate the energies associated with the competing channels involving losses of $\mathrm{RCO}_{2} \mathrm{H}$ or the ligand, L, to form $\mathbf{1 1}$ and 12 respectively. The complexes [(2$\left.\mathrm{PhPy}) \mathrm{Ru}\left(\mathrm{O}_{2} \mathrm{CCH}_{3}\right)\left(\mathrm{C}_{6} \mathrm{H}_{6}\right)\right]^{+}$and $\left[(2-\mathrm{PhPy})_{2} \mathrm{Pd}\left(\mathrm{O}_{2} \mathrm{CCH}_{3}\right)\right]^{+}$exclusively lose acetic acid, while in the case of $\left[(2-\mathrm{PhPy})_{2} \mathrm{Cu}\left(\mathrm{O}_{2} \mathrm{CCH}_{3}\right)\right]^{+}$both reaction channels operate.

DFT calculations were used to calculate the potential energy surfaces and estimate the energies required for the $\mathrm{C}-\mathrm{H}$ activation step coupled with the subsequent loss of the carboxylic acid and for competing ligand loss. The DFT calculations show a common mechanism for $\left[(2-\mathrm{PhPy}) \mathrm{Ru}\left(\mathrm{O}_{2} \mathrm{CCH}_{3}\right)\left(\mathrm{C}_{6} \mathrm{H}_{6}\right)\right]^{+}$and $\left[(2-\mathrm{PhPy})_{2} \mathrm{Pd}\left(\mathrm{O}_{2} \mathrm{CCH}_{3}\right)\right]^{+}$in which the coordination mode of the ligands in $\mathbf{8}$ change to bring the carboxylate and the ortho $\mathrm{C}-\mathrm{H}$ into closer proximity as shown in 9 (Scheme 10). This intermediate is the key precursor to the transition state associated with $\mathrm{C}-\mathrm{H}$ bond activation, which then leads to the cyclometalated intermediate 10, in which the carboxylic acids remains bound to the metal center. Loss of the carboxylic acid leads to the cyclometalated product $\mathbf{1 1}$. In the case of $\left[(2-\mathrm{PhPy})_{2} \mathrm{Cu}\left(\mathrm{O}_{2} \mathrm{CCH}_{3}\right)\right]^{+}, \mathbf{1}$, is the direct precursor to the transition state associated with $\mathrm{C}-\mathrm{H}$ bond activation. For $\left[(2-\mathrm{PhPy}) \mathrm{Ru}\left(\mathrm{O}_{2} \mathrm{CCH}_{3}\right)\left(\mathrm{C}_{6} \mathrm{H}_{6}\right)\right]^{+}$and $[(2-$ $\left.\mathrm{PhPy})_{2} \mathrm{Cu}\left(\mathrm{O}_{2} \mathrm{CCH}_{3}\right)\right]^{+}$the transition state for $\mathrm{C}-\mathrm{H}$ bond activation lies below the final energy associated with loss of acetic acid from 10, while for $\left[(2-\mathrm{PhPy})_{2} \mathrm{Pd}\left(\mathrm{O}_{2} \mathrm{CCH}_{3}\right)\right]^{+}$ it lies above.

This article is protected by copyright. All rights reserved. 


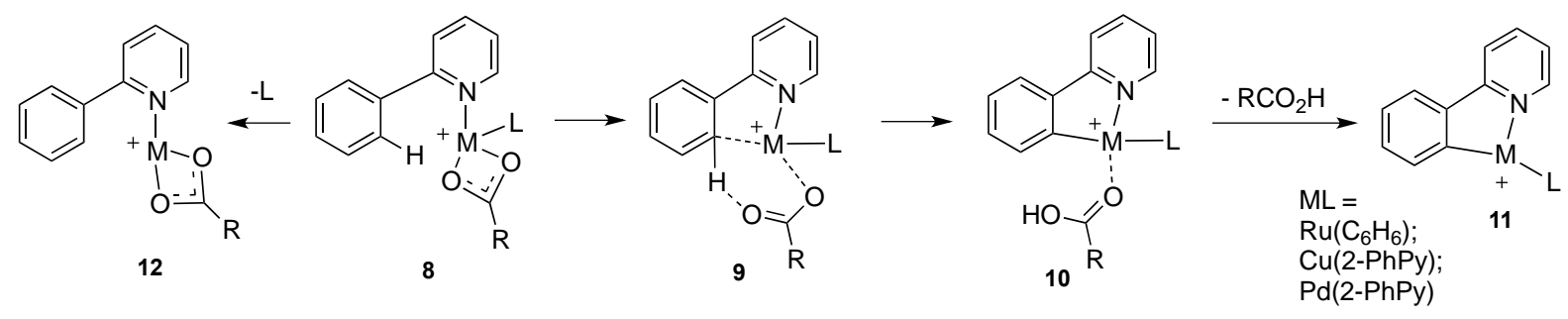

Scheme 10: Carboxylate assisted C-H activation studies in the gas phase (Gray et al., 2015).

The experimentally determined energetics for the reaction channels are in reasonable agreement with the DFT calculations. For $\left[(2-\mathrm{PhPy})_{2} \mathrm{Cu}\left(\mathrm{O}_{2} \mathrm{CCH}_{3}\right)(\mathrm{L})\right]^{+}$they are 138 and $156 \mathrm{~kJ} \mathrm{~mol}^{-1}$, respectively, for acetic acid loss versus 147 and $179 \mathrm{~kJ} \mathrm{~mol}^{-1}$ for 2 phenylpyridine loss. The acetic acid loss channel energetics are 113 and $142 \mathrm{~kJ} \mathrm{~mol}^{-1}$ for $\left[(2-\mathrm{PhPy}) \mathrm{Ru}\left(\mathrm{O}_{2} \mathrm{CCH}_{3}\right)\left(\mathrm{C}_{6} \mathrm{H}_{6}\right)\right]^{+}$and 65 and $83 \mathrm{~kJ}^{-1}$ for $[(2-$ $\left.\mathrm{PhPy})_{2} \mathrm{Pd}\left(\mathrm{O}_{2} \mathrm{CCH}_{3}\right)\right]^{+}$.

The gas-phase IR spectra were measured via infrared multiphoton dissociation spectroscopy and compared to DFT calculations to establish that the structures of [(2$\left.\mathrm{PhPy}) \mathrm{Ru}\left(\mathrm{O}_{2} \mathrm{CCH}_{3}\right)\left(\mathrm{C}_{6} \mathrm{H}_{6}\right)\right]^{+}$and $\left[(2-\mathrm{PhPy})_{2} \mathrm{Cu}\left(\mathrm{O}_{2} \mathrm{CCH}_{3}\right)\right]^{+}$correspond to isomer $\mathbf{1}$, while that of $\left[(2-\mathrm{PhPy})_{2} \mathrm{Pd}\left(\mathrm{O}_{2} \mathrm{CCH}_{3}\right)\right]^{+}$mainly corresponds to isomer $\mathbf{1}$ with minor contributions from $\mathbf{2}$ and $\mathbf{3}$.

Finally, Hammett plots constructed from the CID experiments using different [(2$\left.\mathrm{PhPy})_{2} \mathrm{Cu}\left(\mathrm{O}_{2} \mathrm{CAr}\right)\right]^{+}$complexes revealed that the use of stronger acids accelerates the $\mathrm{C}-\mathrm{H}$ activation step. This is consistent with the DFT-calculated concerted mechanism in which carbon-metal bond preformation plays a key role. Thus carboxylates derived from stronger acids make the metal atom more electrophilic and therefore shift the reaction towards the formation of $\mathrm{C}-\mathrm{H}$ activated products.

This article is protected by copyright. All rights reserved. 


\section{Comparisons with condensed-phase systems}

Many solution-phase studies use various additives in $\mathrm{C}-\mathrm{H}$ bond functionalization reactions to enhance performance. For example, changing the nature of the carboxylate can influence yields of products (Lebrasseur\&Larrosa, 2008). A key finding in Roithová's study (Gray et al., 2015) is that the competition between ligand loss and loss of the carboxylic acid in $\left[(2-\mathrm{PhPy})_{2} \mathrm{Cu}\left(\mathrm{O}_{2} \mathrm{CAr}\right)\right]^{+}$complexes provides information on the "acid effect" associated with carboxylate assisted C-H bond activation (Vana et al., 2019). This is one of the key factors in optimizing reaction conditions, where the aim is to find a balance between two opposing effects of the carboxylic acid in the reaction mixture: generation of a more reactive palladium catalyst versus deactivation of a substrate by its protonation.

\section{Perspectives}

A key challenge of studying the mechanistic features of catalytic $\mathrm{C}-\mathrm{H}$ bond functionalization in solution is to decouple the $\mathrm{C}-\mathrm{H}$ bond activation step from the subsequent reactions of the cyclometallated intermediate. Whilst stoichiometric variants aimed at studying the cyclometallation reaction can provide valuable information, the precise nature of the species responsible for the $\mathrm{C}-\mathrm{H}$ bond activation step can be complicated by aggregation and complex equilibria. As a consequence DFT calculations have played a crucial role in examining the mechanistic features of $\mathrm{C}-\mathrm{H}$ bond activation (Davies et al., 2017). By studying isolated complexes in the gas phase, experimental data can be used to provide valuable benchmarks for theory.

This article is protected by copyright. All rights reserved. 


\section{Remote functionalization of carboxylic acids and their derivatives}

\section{A. Definition of the catalytic problem}

Mother nature uses a diiron active site within fatty acid desaturases and related enzymes to carry out $\mathrm{O}_{2}$-dependent dehydrogenations of unactivated $\mathrm{C}-\mathrm{H}$ bonds remote to the carboxylate group (Shanklin\&Cahoon, 1998; Behrouzian\&Buist, 2003; Fox et al., 2004; Shanklin et al., 2009). While the precise mechanistic details of these oxidation reactions are the subject of ongoing research, the following key features are highlighted for stearoyl-acyl carrier protein $\Delta^{9}$-desaturase ( $\left.\Delta 9 \mathrm{D}\right)$ (Scheme 11) (Fox et al., 2004; Chalupsky et al., 2014):

(i) The dehydrogenation is regio- and stereospecific, producing the nutrionally valuable fatty acid, oleic acid, which contains a cis double bond at position C9-C10 (Scheme 11a) (Fox et al., 2004).

(ii) There is an entropy cost to pay as the fatty acid chain needs to adopt a specific eclipsed conformation to present the reactive hydrogens to the active site (Scheme 11b) (Fox et al., 2004).

(iii) In the enzyme-active site there are two iron atoms that are bound by four glutamates (Glu105, Glu 196, Glu 143 and Glu 229) and two histidines (His 146 and His232) and dehydrogenation involves changes in the oxidation state of the iron sites (Chalupsky et al., 2014). Starting from 13 (Scheme 11c) in which both iron atoms are in the +2 oxidation state, binding of $\mathrm{O}_{2}$ and the substrate produces a $1,2-\mu$ peroxy $\mathrm{Fe}^{\mathrm{III}} \mathrm{Fe}^{\mathrm{III}}$ intermediate, 14. Protonation produces the $1,1-\mu$ hydroperoxy species, $\mathbf{1 5}$, which then abstracts an $\mathrm{H}$ atom from the $\mathrm{C} 10$ site of the substrate to produce a $\mathrm{Fe}^{\mathrm{IV}}$-oxo unit in intermediate 16. This oxo intermediate abstracts the second $\mathrm{H}$ atom from $\mathrm{C} 9$ to produce

This article is protected by copyright. All rights reserved. 
$\mathbf{1 7}$ in which both iron atoms are in the +3 oxidation state. Protonation of the iron atoms bound hydroxide followed by loss of two water molecules and the dehydrogenated substrate and 2-electron reduction closes the catalytic cycle to reform $\mathbf{1 3}$.

(A)

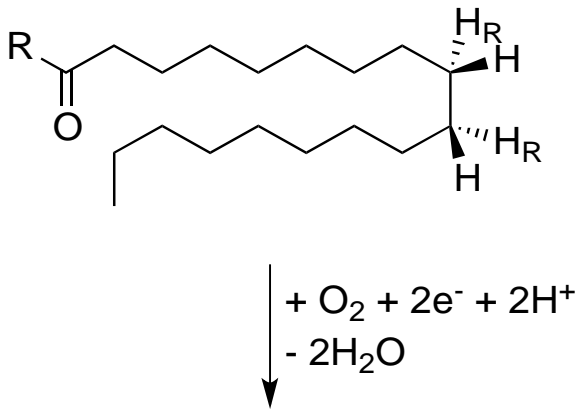<smiles>[R]C(=O)CCCCCCCCCCCCCCCC</smiles>

(C)

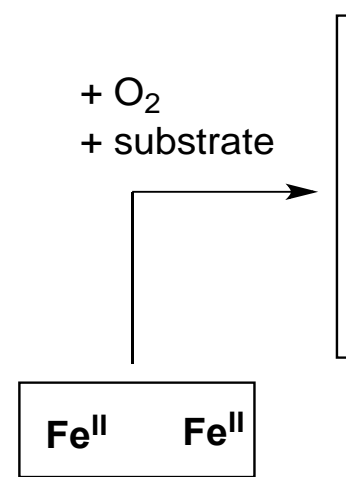

13

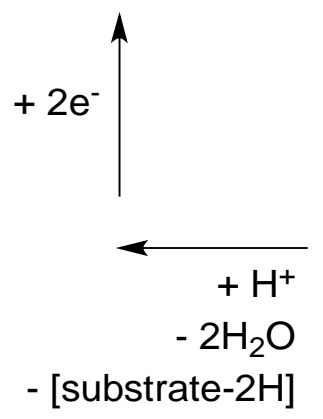

(B)

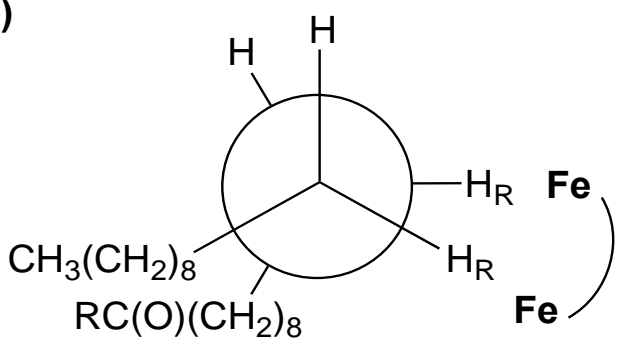

Enzyme active site

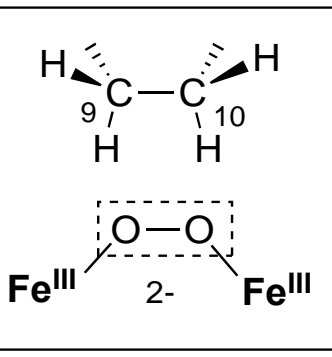

14

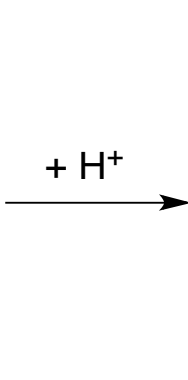

$\mathrm{Fe}^{\text {III }} \mathrm{Fe}^{\text {III }}$

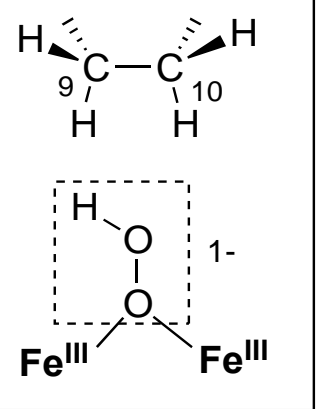

15

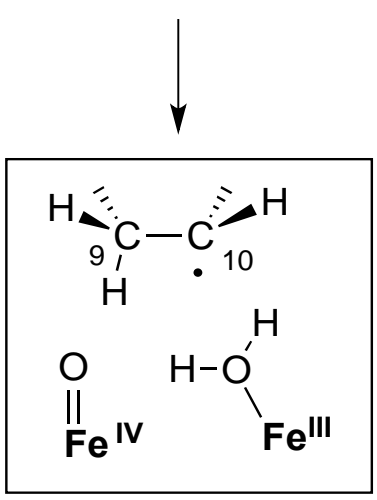

16

Scheme 11: Key features of stearoyl-acyl carrier protein $\Delta^{9}$-desaturase $(\Delta 9 \mathrm{D})$ : (a) regio- and stereospecific dehydrogenation forms oleic acid; (b) entropy cost associated with forming the required eclipsed conformation; (c) key iron intermediates at the enzyme active site, which are formed during the dehydrogenation reactions - the

This article is protected by copyright. All rights reserved. 
protein ligand binding sites, which consist of four glutamates (Glu105, Glu 196, Glu 143 and Glu 229) and two histidines (His 146 and His232) have been omitted for clarity.

Given that fatty acids are widely available from renewable biomass, there is considerable interest in developing catalysts that mimic these enzymes via the activation of $\mathrm{C}-\mathrm{H}$ and/or $\mathrm{C}-\mathrm{C}$ bonds of long-chain fatty acids or their derivatives.

\section{B. Insights from gas-phase studies}

Schwarz pioneered the use of deuterium labeling and gas-phase mass spectrometrybased studies (Lebrilla et al., 1987) on remote functionalization (Breslow, 1972; Breslow, 1980) of long-chain alkanes containing a functional group to "anchor" the substrate to the transition metal center. Since this topic has been the subject of reviews (Schwarz, 1989; Roithová \& Schröder, 2010), here I only focus on carboxylic acids and their related derivatives (carboxylic acid esters, amides and nitriles).

\section{C-H and C-C bond activation}

\section{Carboxylic acids and amides.}

Two studies have used the metastable mass spectrometry method in conjunction with regiospecifically deuterium labeled substrates to examine $\mathrm{C}-\mathrm{H}$ and $\mathrm{C}-\mathrm{C}$ bond activation (Scheme 12) in the $[\mathrm{Fe}(\mathrm{RC}(\mathrm{O}) \mathrm{X})]^{+}$complexes $\left(\mathrm{X}=\mathrm{OH}\right.$ (Schröder et al., 1994) and $\mathrm{NH}_{2}$ (Loos et al., 2002)). C-H bond activation dominates over C-C bond activation in all cases, while deuterium labeling of the terminal methyl provides information on the regioselectivity of $\mathrm{C}-\mathrm{H}$ bond activation. Dehydrogenation is regiospecific for butanoic acid, pentanoic acid and pentanamide. For hexanoic acid, dehydrogenation occurs at both C4-C5 and C5-C6. As the carbon chain length increases, the site selectivity decreases further. An examination of the amount of $\mathrm{HD}$ loss relative to $\mathrm{H}_{2}$ loss reveals 
that the propensity for $\mathrm{C}-\mathrm{H}$ activation of the terminal methyl group reaches a minimum for heptanoic acid $(n=3)$, but then rises again for the longer chain acids $(n=4$ and 5$)$.

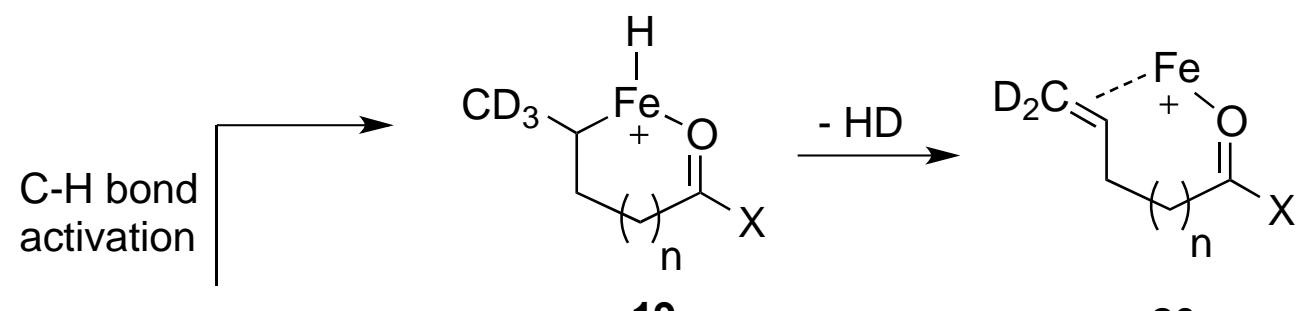<smiles>[X]C(=O)C(C)NCCC(C)(C)C</smiles>

18

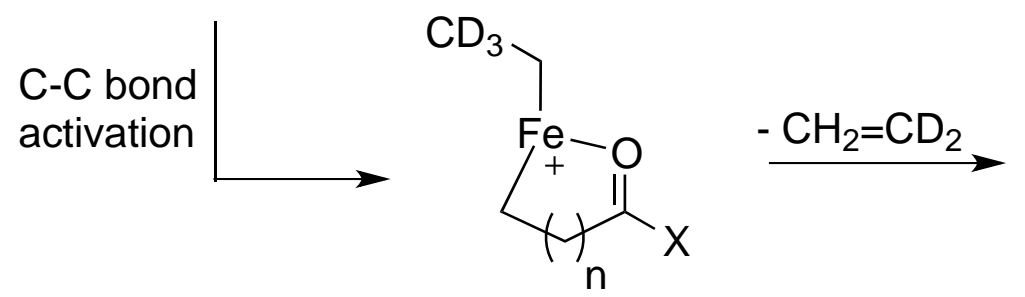

21<smiles>[R]CC(C)C([Y])C(=O)O[O+]</smiles>

22

\begin{tabular}{|l|l|l|l|l|}
\hline $\mathrm{X}=$ & $\mathrm{n}=$ & $-\mathrm{H}_{2}$ & $-\mathrm{HD}$ & $-\mathrm{CH}_{2}=\mathrm{CD}_{2}$ \\
\hline $\mathrm{OH}$ & 0 & 0 & 100 & 1 \\
\hline $\mathrm{OH}$ & 1 & 0 & 100 & 15 \\
\hline $\mathrm{NH}_{2}$ & 1 & 0 & 100 & 20 \\
\hline $\mathrm{OH}$ & 2 & 80 & 6 & 30 \\
\hline $\mathrm{OH}$ & 3 & 80 & 5 & 7 \\
\hline $\mathrm{OH}$ & 4 & 100 & 17 & 10 \\
\hline $\mathrm{OH}$ & 5 & 100 & 15 & 5 \\
\hline
\end{tabular}

This article is protected by copyright. All rights reserved. 
Scheme 12: Gas-phase remote $\mathrm{C}-\mathrm{H}$ and $\mathrm{C}-\mathrm{C}$ bond activation of carboxylic acids and amides mediated by bare $\mathrm{Fe}^{+}$. Relative yields of $\mathrm{H}_{2}, \mathrm{HD}$ and $\mathrm{CH}_{2}=\mathrm{CD}_{2}$ are given as a function of the most abundant fragment ion, assigned as $100 \%$. Other fragment ions are omitted.

\section{Nitriles.}

Nitriles are directly related to carboxylic acids as the products of dehydration of primary amides (reaction 5, Scheme 1). Long-chain nitriles were the first substrates to have been examined for their ability to undergo remote functionalization by transition metal cations (Lebrilla\& Schulze\& Schwarz, 1987), and they have been more widely studied than any other substrate (Lebrilla et al., 1987,Lebrilla et al., 1987,Lebrilla et al., 1987,Stepnowski\& Allison, 1988,Czekay et al., 1989,Czekay et al., 1989,Eller et al., 1990,Eller et al., 1991,Chen\& Miller, 1991,Holthausen et al., 1997,Hornung et al., 1995,Stoeckigt et al., 1994,Gibson, 1999,Schlangen et al., 2005). The role of chain length, chain branching and the metal on remote functionalization of nitriles has been probed. The catalog of metals studied include the bare metal ions $\mathrm{Fe}^{+}, \mathrm{Co}^{+}, \mathrm{Ni}^{+}, \mathrm{Cu}^{+}$ (Lebrilla\& Drewello\& Schwarz, 1987, Lebrilla\& Drewello\& Schwarz, 1987, Lebrilla\& Drewello\& Schwarz, 1987, Stepnowski\& Allison, 1988, Czekay\& Drewello\& Eller\& Zummack\& Schwarz, 1989, Czekay\& Drewello\& Schwarz, 1989, Eller\& Zummack\& Schwarz, 1990, Eller\& Zummack\& Schwarz\& Roth\& Freiser, 1991, Chen\& Miller, 1991, Holthausen\& Hornung\& Schröder \& Sen\& Koch\& Schwarz, 1997, Hornung\&

Schröder \& Schwarz, 1995), the organometallic cation $\mathrm{CH}_{3} \mathrm{Fe}^{+}$(Stoeckigt\& Sen\& Schwarz, 1994), the actinide oxide cations $\mathrm{AnO}^{+}(\mathrm{An}=\mathrm{Th}, \mathrm{U}, \mathrm{Np}, \mathrm{Pu}, \mathrm{Am})$ (Gibson, 1999) as well as the homo- and heteronuclear cluster ions $\mathrm{MM}^{ \pm}\left(\mathrm{M}, \mathrm{M}^{\prime}=\mathrm{Fe}, \mathrm{Co}, \mathrm{Ni}\right)$ (Schlangen\& Schroeder\& Schwarz, 2005). In addition, this class of substrate is the only 
one for which DFT calculations have been carried out (Holthausen\& Hornung\& Schröder \& Sen\& Koch\& Schwarz, 1997).

As described above for the carboxylic acid and amide substrates, the key to determining the regioselectivity and mechanisms for $\mathrm{C}-\mathrm{H}$ and $\mathrm{C}-\mathrm{C}$ bond activation has been the use of deuterium labeled nitriles, which not only establishes the site(s) of $\mathrm{C}-\mathrm{H}$ bond activation, but also provide kinetic isotope effects. Rather than reviewing all the work carried on nitriles, key data on the DFT calculated activation energies for dehydrogenation at various remote sites versus the experimentally determined regioselectivies for the cases of bare $\mathrm{Fe}^{+}$and $\mathrm{Co}^{+}$is summarized in Scheme 13 (Holthausen\& Hornung\& Schröder \& Sen\& Koch\& Schwarz, 1997).

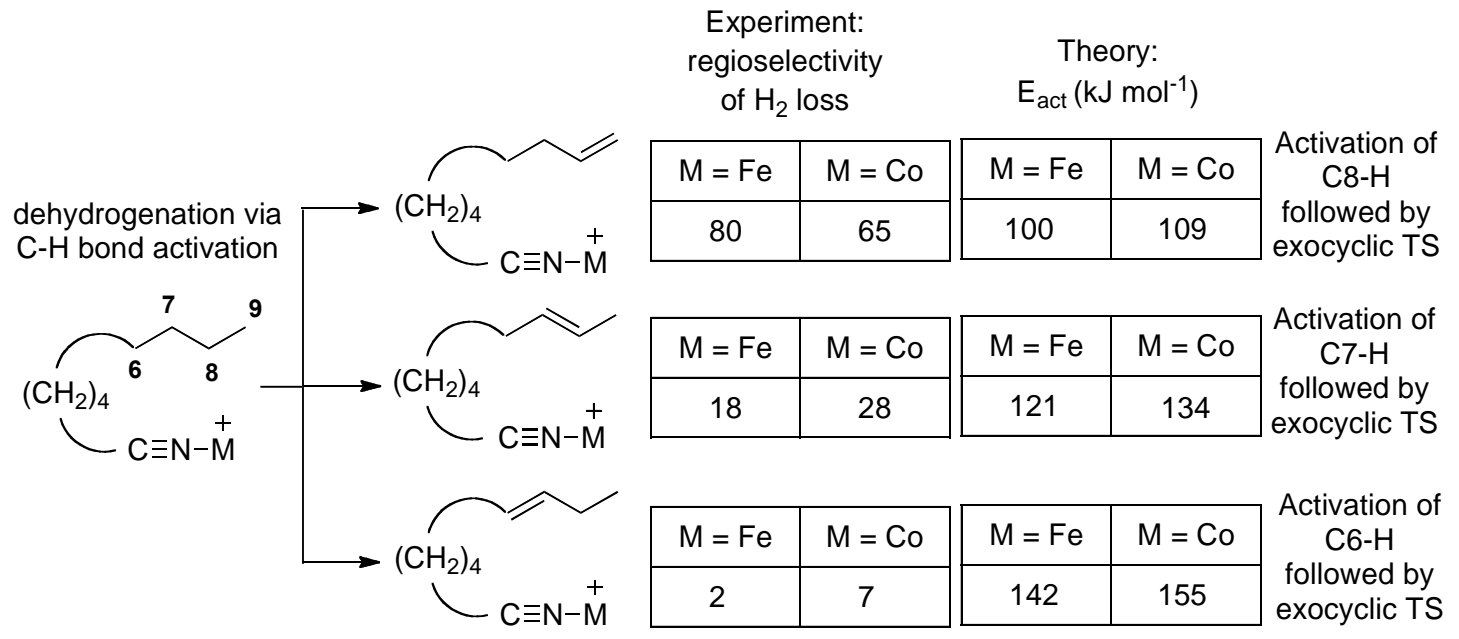

Scheme 13: Gas-phase dehydrogenation via remote $\mathrm{C}-\mathrm{H}$ bond activation of nonanitrile mediated by bare $\mathrm{Fe}^{+}$or $\mathrm{Co}^{+}$. Experimental regioselectivities are determined from deuterium labeling experiments. Only the lowest DFT-calculated activation energy (in $\mathrm{kJ} \mathrm{mol}^{-1}$ ) for the TS associated with loss of $\mathrm{H}_{2}$ from the organometallic ion formed via activation of the specified $\mathrm{C}-\mathrm{H}$ bond is given.

As for all remote functionalization reactions, dehydrogenation is stepwise, being triggered by initial $\mathrm{C}-\mathrm{H}$ bond insertion to give an organometallic ion containing a hydride (cf 2, Scheme 12 above), which then initiates $\mathrm{H}_{2}$ loss. Rather than adopting the classic "zigzag" motif of alkanes, the alkyl chain folds back, allowing interaction of the

This article is protected by copyright. All rights reserved. 
metal ion to both the cyano group as well as the remote $\mathrm{C}-\mathrm{H}$ bonds via agostic interactions. This structure is the precursor to remote $\mathrm{C}-\mathrm{H}$ activation. For a given organometallic, there are several transition states for $\mathrm{H}_{2}$ loss. For example, for the organometallic formed via activation of the $\mathrm{C} 8-\mathrm{H}$ bond of nonanitrile, there are 4 transition states: endocyclic or exocyclic transition states involving $\mathrm{C} 7-\mathrm{H}$ to give the C7-C8 alkene; endocyclic or exocyclic transition states involving $\mathrm{C} 9-\mathrm{H}$ to give the $\mathrm{C} 8$ C9 alkene. The DFT calculations reveal these transition states to be multicenter, and there is good agreement between the experimentally determined regioselectivities and the activation energy associated with the lowest-energy transition state for $\mathrm{H}_{2}$ loss (Scheme 13).

\section{Hydroxylation of carboxylic acid esters.}

An alternative way of activating a $\mathrm{C}-\mathrm{H}$ bond is to use a high-valent metal oxo complex rather than a bare metal ion. Such high-valent metal complexes can be formed by electrospray ionization of appropriate precursors followed by CID to unleash the radical site (O'Hair, 2010). Shaffer et al have described the intramolecular hydroxylation of remote $\mathrm{C}-\mathrm{H}$ bonds of an carboxylic acid ester (Scheme 14) (Shaffer et al., 2012). A tailor-made ligand consisting of an carboxylic acid ester anchored to a bipyridine ligand was synthesized and coordinated to copper nitrate, which upon ESI produced the $\mathrm{Cu}(\mathrm{II})$ complex, 23. CID of this complex gave rise to a competition between carboxylic acid ester fragmentation via the loss of octene to give $\mathbf{2 4}$ and the desired unmasking of the oxo site to give 25 . Based on a combination of deuterium labeling experiments and the novel application of ion-mobility to examine the products of these CID reactions, Shaffer e al were able to show that $\mathbf{1} / \mathrm{CuO}^{+}$rapidly undergoes remote $\mathrm{C}-\mathrm{H}$ bond activation at $\mathrm{C} 8, \mathrm{C} 7$ and $\mathrm{C} 6$ positions to produce the alcohols $\mathbf{2 6}, \mathbf{2 7}$, and $\mathbf{2 8}$. CID of

This article is protected by copyright. All rights reserved. 
these alcohols results in a competition between carboxylic acid ester fragmentation to give 29 and dehydration to give $\mathbf{3 0}$ and/or $\mathbf{3 1}$. The assignments of these structures were confirmed by a comparison of their ion-mobility arrival times with those of independently synthesized authentic standards. By considering the ratios of losses of $\mathrm{H}_{2} \mathrm{O}$ and $\mathrm{HOD}$ for the deuterated analogues $\left[8,8,8-\mathrm{D}_{3}\right]$ and $\left[7,7-\mathrm{D}_{2}\right]$ of $\mathbf{2 6}, \mathbf{2 7}$, and $\mathbf{2 8}$ together with the kinetic isotope effects, the regioselectivity for dehydrogenation was estimated to be $58 \%$ across $\mathrm{C} 7$ and $\mathrm{C} 8,30 \%$ across $\mathrm{C} 6$ and $\mathrm{C} 7$, and $12 \%$ from unidentified positions (C1-C6).

While a complete catalytic cycle was not achieved in the gas phase, the authors suggested a possible solution-phase cycle requiring two further steps to close the cycle. They involve transesterification of $\mathbf{2 6}, \mathbf{2 7}$, and $\mathbf{2 8}$ by reaction with octanol, followed by reoxidation of the $\mathrm{Cu}$ centre to reform 25 .

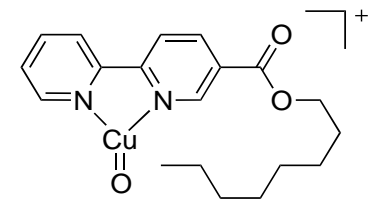

25

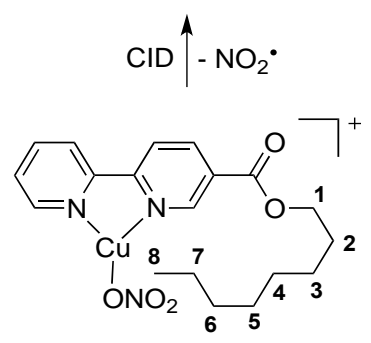

23

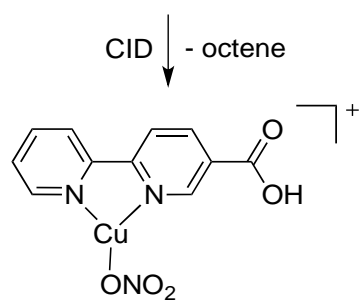

24

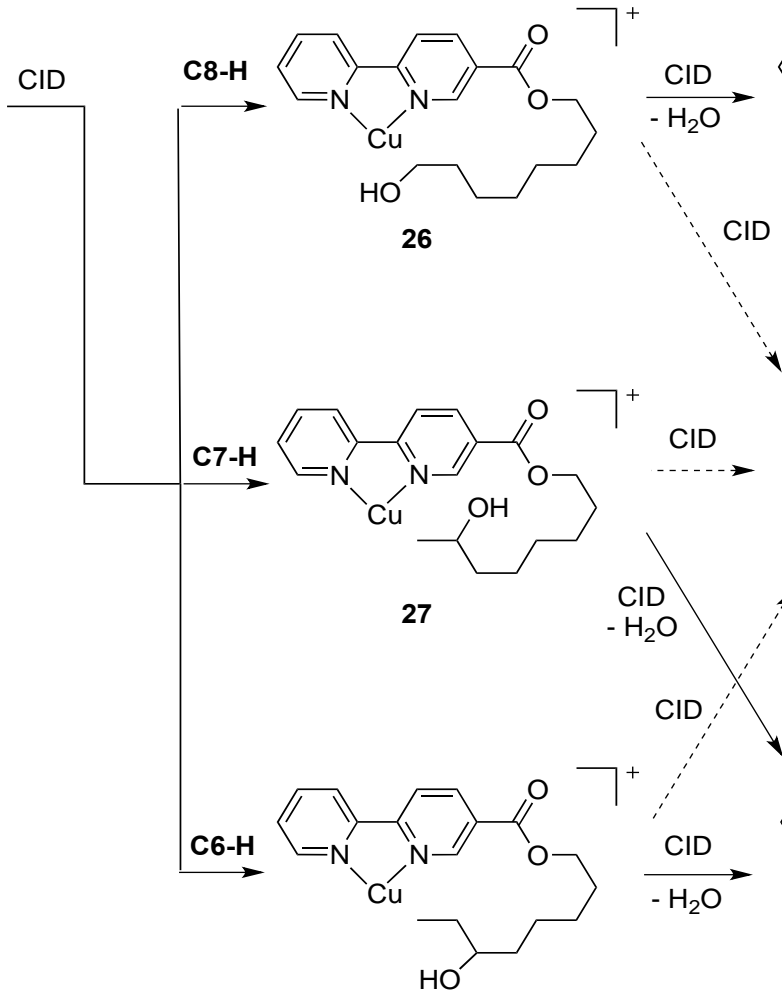

28

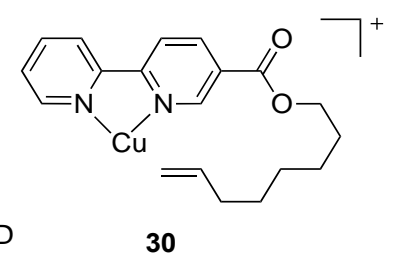

30

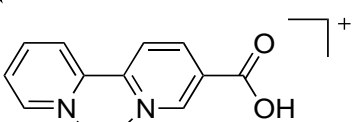

29

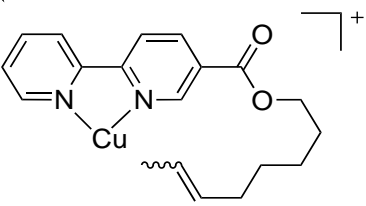

31

Scheme 14: Remote hydroxylation of the $\mathrm{C}-\mathrm{H}$ bonds of a tethered carboxylic acid ester by a high valent copper oxide site. A potential catalytic cycle was suggested (Shaffer et al., 2012). The dashed arrows represent ester fragmentation where the neutral product(s) are unknown.

This article is protected by copyright. All rights reserved. 


\section{Comparisons with condensed-phase systems}

\section{Dehydrogenation via $\mathrm{C}-\mathrm{H}$ bond activation}

Whittemore et al have described the site-selective alkyl dehydrogenation of a coordinated acylphosphine ligand (Scheme 15) (Whittemore et al., 2012). While carboxylic acids, 32, were not directly activated, they can be transformed to acylphosphines, 33, which are now suitable ligands to bind to an iridium centre, to provide the iridium complexes, 34. Abstraction of the chloride ligands by $\mathrm{Ag}^{+}$provides a vacant site for $\mathrm{C}-\mathrm{H}$ bond activation to give the coordinated olefin hydride complexes 35, which were characterized by NMR spectroscopy and X-ray crystallography (in the case of 35a). The activation of the $\beta$ - and $\gamma-\mathrm{C}-\mathrm{H}$ bonds of 33 in the condensed phase is related to the activation of the same bonds in pentanoic acid by $\mathrm{Fe}^{+}$in the gas phase (Scheme 12, $\mathrm{X}=\mathrm{OH}$ and $\mathrm{n}=1$ ).

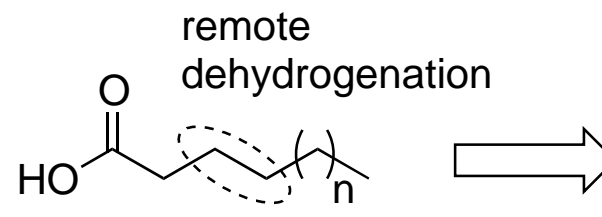

32

$$
\mathbf{a}: \mathrm{n}=2 ; \mathbf{b}: \mathrm{n}=11
$$

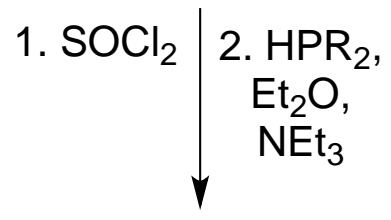

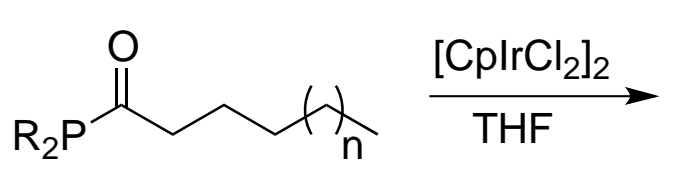
33

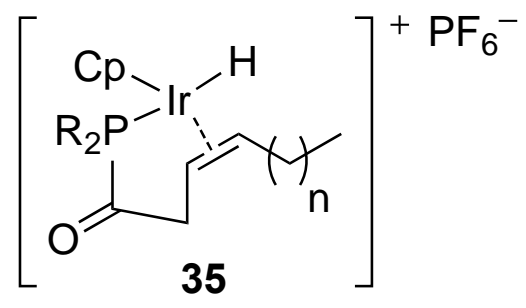

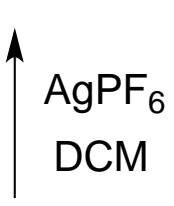

Scheme 15: Remote dehydrogenation of carboxylic acids, 32, via acylphosphine $\mathbf{3 3}$ derivatization followed by coordination to an iridium centre, 34, and organometallic formation, 35 (Whittemore et al., 2012).

This article is protected by copyright. All rights reserved. 


\section{Hydroxylation}

What condensed-phase studies are of relevance to Shaffer et al's gas-phase study on the hydroxylation of C-H bonds of a tethered carboxylic acid ester (Scheme 14)? While there have been numerous studies on the oxidation of carboxylic acids and their derivatives by fatty acid desaturases and related enzymes as well as enzyme model mimics, here I focus on two examples, both using iron oxo chemistry to achieve remote hydroxylation of aliphatic chains of carboxylic acids or carboxylic acid esters.

In one of the earliest studies of a model system for cytochrome P-450, Groves et al highlighted that the regioselectivity of hydroxylation in iron oxo porphyrin systems is influenced by proximity effects (Groves et al., 1979). Thus they observed a preference for C4 and C5 hydroxylation in the intramolecular oxidation reactions (Scheme 16). Just like Shaffer et al's gas-phase study, these reactions are not catalytic.

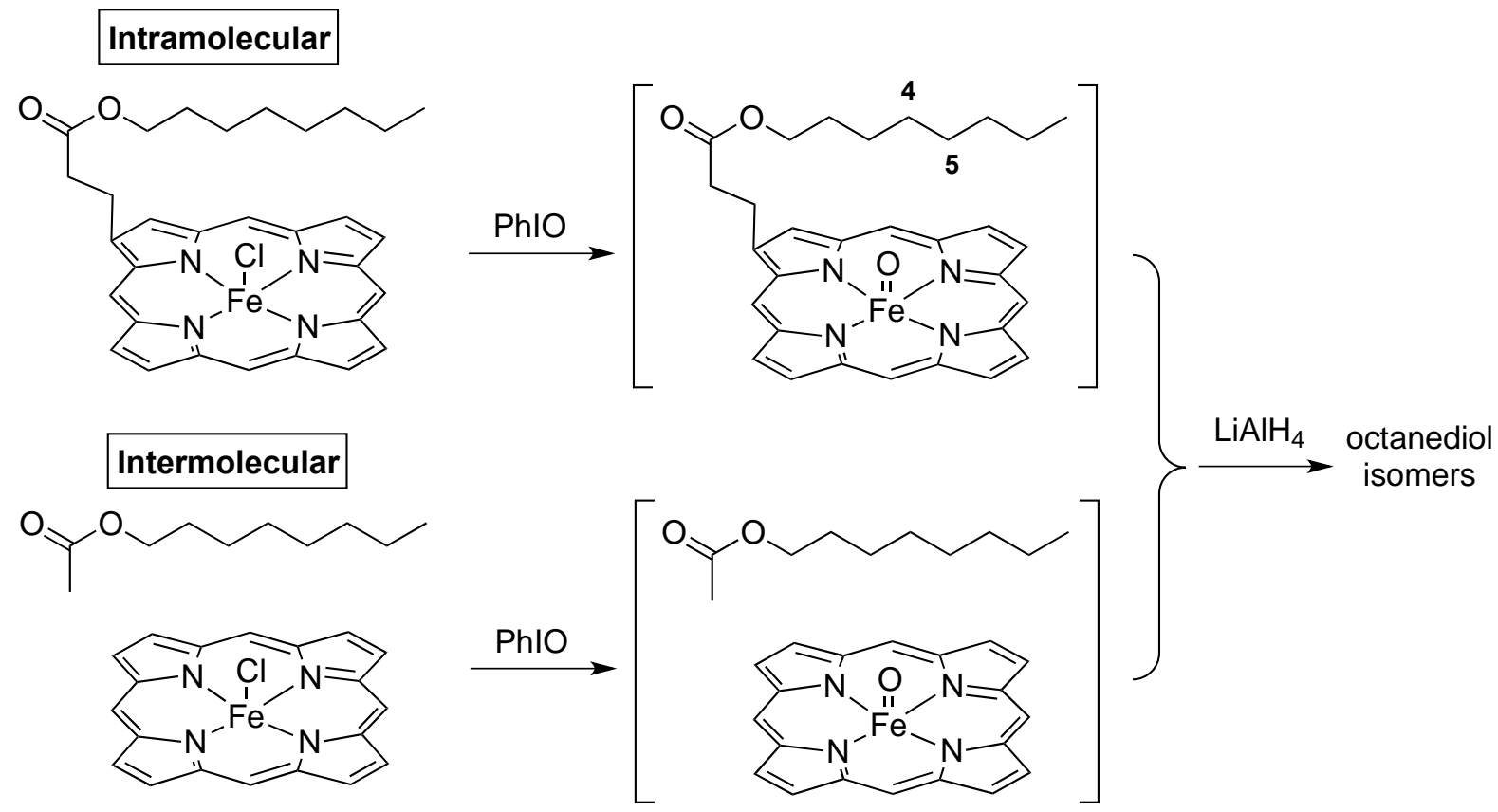

This article is protected by copyright. All rights reserved. 


\begin{tabular}{|l|l|l|l|l|l|l|}
\hline octanediol & 1,2 & 1,3 & 1,4 & 1,5 & 1,6 & 1,7 \\
\hline intramolecular & $<2$ & 15 & 28 & 30 & 13 & 14 \\
\hline intermolecular & $<2$ & 17 & 15 & 21 & 22 & 24 \\
\hline
\end{tabular}

Scheme 16: Regioselectivity of intramolecular versus intermolecular oxidation of octyl carboxylic acid esters via hydroxylation. The relative yields of the octanediols formed are given in the table. The structures of the porphyrin systems used have been simplified.

More recently, Bigi et al have examined the intermolecular catalytic hydroxylation of a series of carboxylic acids. The carboxylate group coordinates to the metal centre of the non-heme $\mathrm{Fe}(\mathrm{PDP})$ catalyst to override steric and stereoelectronic effects that are observed for related carboxylic acid ester substrates. The ultimate products of these hydroxylation reactions are lactones, and based upon ${ }^{18} \mathrm{O}$ labeling studies, the proposed mechanism (Scheme 17) involves $\mathrm{C}-\mathrm{H}$ abstraction followed by hydroxyl rebound. The hydroxy carboxylic acids then undergo lactonization (Bigi et al., 2012).

This article is protected by copyright. All rights reserved. 
<smiles>[2H][C@@H](C)CCC(=O)O</smiles>

$$
\underset{\substack{\mathrm{CH} \mathrm{CN}_{3}, \mathrm{RT}, 30 \mathrm{~min}}}{\stackrel{\mathrm{Fe}(\mathrm{PDP})(5 \mathrm{~mol} \%)}{\mathrm{H}_{2} \mathrm{O}_{2}(1.2 \mathrm{eq})}}
$$

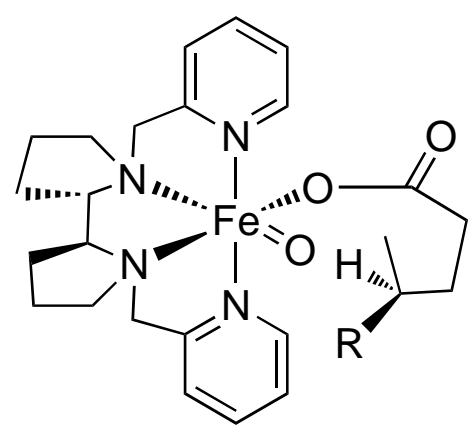
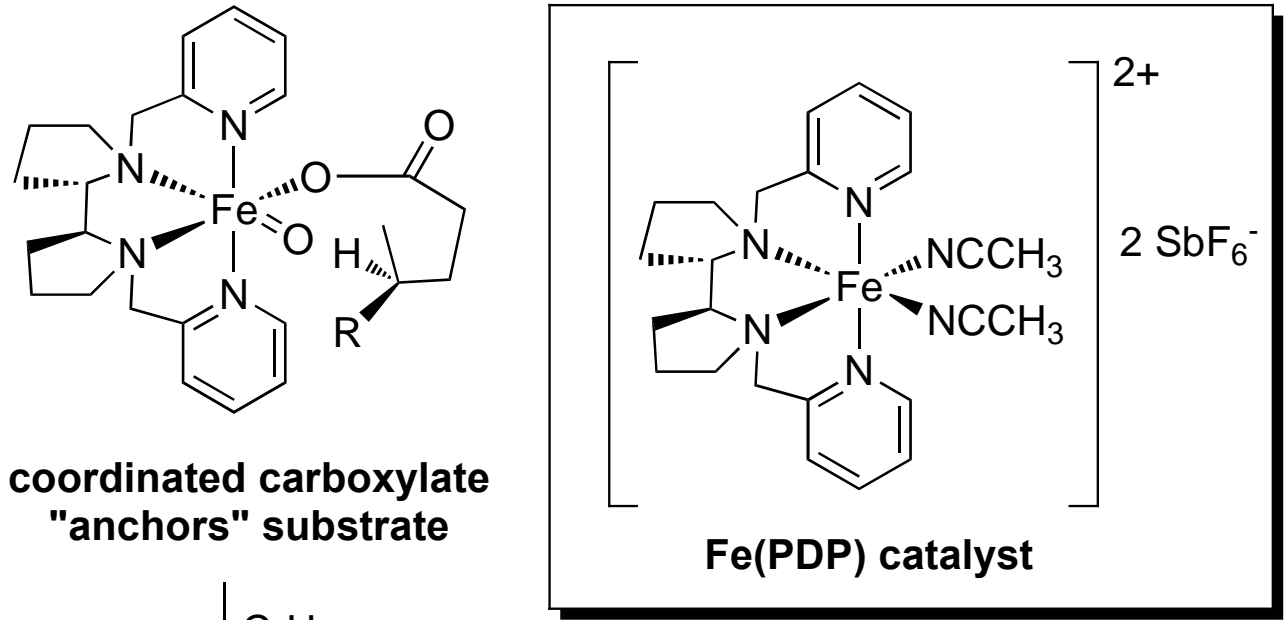

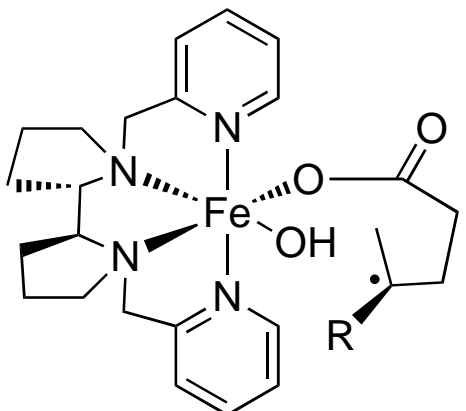

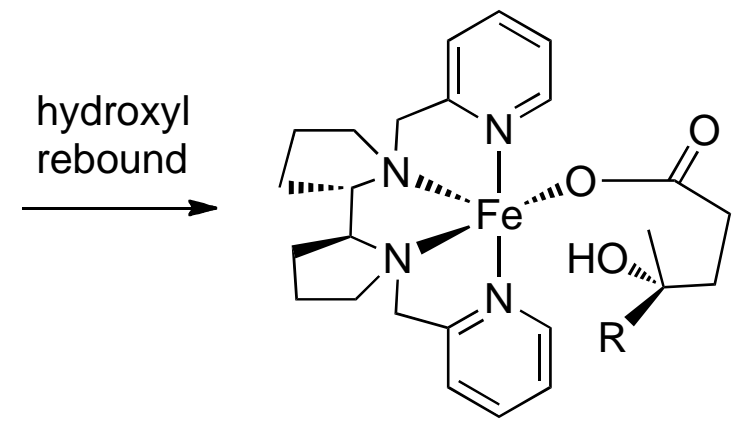

Scheme 17: Remote hydroxylation of carboxylic acid substrates by a non-heme $\mathrm{Fe}(\mathrm{PDP})$ catalyst. Key mechanistic features adapted from (Bigi et al., 2012).

\section{Perspectives}

In a landmark review on C-H bond activation in the gas phase (Roithová \& Schröder, 2010), Roithová and Schröder had the following comments to make regarding the transfer of concepts from gas-phase studies on remote functionalization to the condensed phase:

“Nevertheless, we may ask why the promising concept has not been pursued further and why other research areas have not adopted the ideas and strategies developed in This article is protected by copyright. All rights reserved. 
the course of this research. In a nutshell, the answer is that the concept is attractive as an idea, but the transfer from the mass spectrometric scale to bulk processes rapidly turned out to be impossible. Thus, not only are most of the metal ions in the unrealistic oxidation state $M^{I}$, but moreover in almost all cases when additional ligands were added, the ability of the complexes to activate either $C-H$ or $C-C$ bonds was quenched completely.”

The recent publication by Whittemore et al (Scheme 15) is an important breakthrough (Whittemore et al., 2012). It demonstrates that even for metal complexes in "realistic" oxidation states and decorated with ligands, reactivity is not quenched. Thus the substrate can be taken up, anchored to the metal site and then undergo remote $\mathrm{C}-\mathrm{H}$ bond activation to form an alkene. Clearly the choice of the metal complex is important, and the metal complexes that have been shown to activate methane in solution appear to be good candidates to re-engineer ("tune" (Shul'pin, 2013)) for remote C-H bond activation of substrates.

Perhaps the most exciting approach is the bio-inspired use of high-valent metal oxo complexes to remotely activate $\mathrm{C}-\mathrm{H}$ bonds. This is an active area of research and is being driven by a paradigm shift in the way organic chemists think of a $\mathrm{C}-\mathrm{H}$ bond of an alkyl group in an organic molecule. Rather than regard them as an "inert" bond we are on the verge of categorizing them as a potential "functional group" that can be manipulated and transformed in organic synthesis (Godula\&Sames, 2006; White, 2012A\&B). This represents a potential step change in the way organic molecules are constructed. As Godula and Sames have noted "by viewing $\boldsymbol{C}$-H bonds as ubiquitous functionality, we are opening a new chapter in organic synthesis with many exciting opportunities”.(Godula\&Sames, 2006)

This article is protected by copyright. All rights reserved. 


\section{Decarboxylative C-C bond coupling of carboxylic acids}

\section{A. Definition of the catalytic problem}

Once an organometallic complex is formed via decarboxylation, its coordinated organic ligands can undergo coupling with each other under unimolecular conditions or via bimolecular reactions with an organic substrate. Given the diversity of organometallic complexes that can be formed via decarboxylation and the large potential number of organic substrates that can be used, there is significant scope for developing new catalytic variants of known reactions as well as the opportunity of discovering new types of reactivity. Here I focus on two classes of unimolecular $\mathrm{C}-\mathrm{C}$ bond coupling reactions and two types of $\mathrm{C}-\mathrm{C}$ bond coupling reactions.

\section{B. Insights from gas-phase studies}

Unimolecular coupling reactions of two organic ligands formed via double decarboxylation.

\section{Dehydro coupling of two acetate ligands}

By exploring the gas-phase unimolecular chemistry of coinage metal organometallates $\left[\mathrm{CH}_{3} \mathrm{MR}\right]^{-}\left(\mathrm{M}=\mathrm{Cu}, \mathrm{Ag}\right.$ or $\mathrm{Au}, \mathrm{R}=\mathrm{CH}_{3}, \mathrm{CH}_{3} \mathrm{CH}_{2}, \mathrm{CH}_{3} \mathrm{CH}_{2} \mathrm{CH}_{2},\left(\mathrm{CH}_{3}\right)_{2} \mathrm{CH},\left(\mathrm{CH}_{3}\right)_{3} \mathrm{C}$, $\mathrm{CH}_{2} \mathrm{CHCH}_{2}, \mathrm{PhCH}_{2}$ and $\mathrm{Ph}$ ), we have discovered a new type of reaction - copper promoted dehydro-decarboxylative coupling of two acetate ligands (eq. 7). This involves a multistep series of reactions that has been explored using the multistage mass spectrometry capabilities of an ion trap mass spectrometer as well as DFT calculations (Rijs et al., 2008; Rijs et al., 2010). Overall, the sequence corresponds to: doubledecarboxylation (eqs 8 and 9), with the second decarboxylation being in competition with loss of the acetate ligand (eq. 10); rearrangement of the dimethyl cuprate anion This article is protected by copyright. All rights reserved. 
into $\left[\mathrm{CH}_{3} \mathrm{CH}_{2} \mathrm{MH}\right]^{-}$(eq. 11), which has the same $\mathrm{m} / \mathrm{z}$ value, a reaction that is in competition with bond homolysis (eq. 12); subsequent fragmentation of $\left[\mathrm{CH}_{3} \mathrm{CH}_{2} \mathrm{MH}\right]^{-}$ via $\beta$-hydride elimination (eq. 13). The key reaction that facilitates $\mathrm{C}$ - $\mathrm{C}$ bond coupling is the 1,2-dyotropic rearrangement (eq. 11) (Fernandez et al., 2009; Gutierrez\&Tantillo, 2012), while the subsequent fragmentation "reports" on the rearrangement reaction (Figure 3). Related reactions do not work as well for the silver and gold analogues, which is largely due to the fact that the competing bond homolysis reactions (cf eq. 12) have lower energies than the barrier for the 1,2-dyotropic rearrangement (cf eq. 11) (Rijs\& O'Hair, 2009; Rijs\&O'Hair, 2010; Rijs et al., 2010).

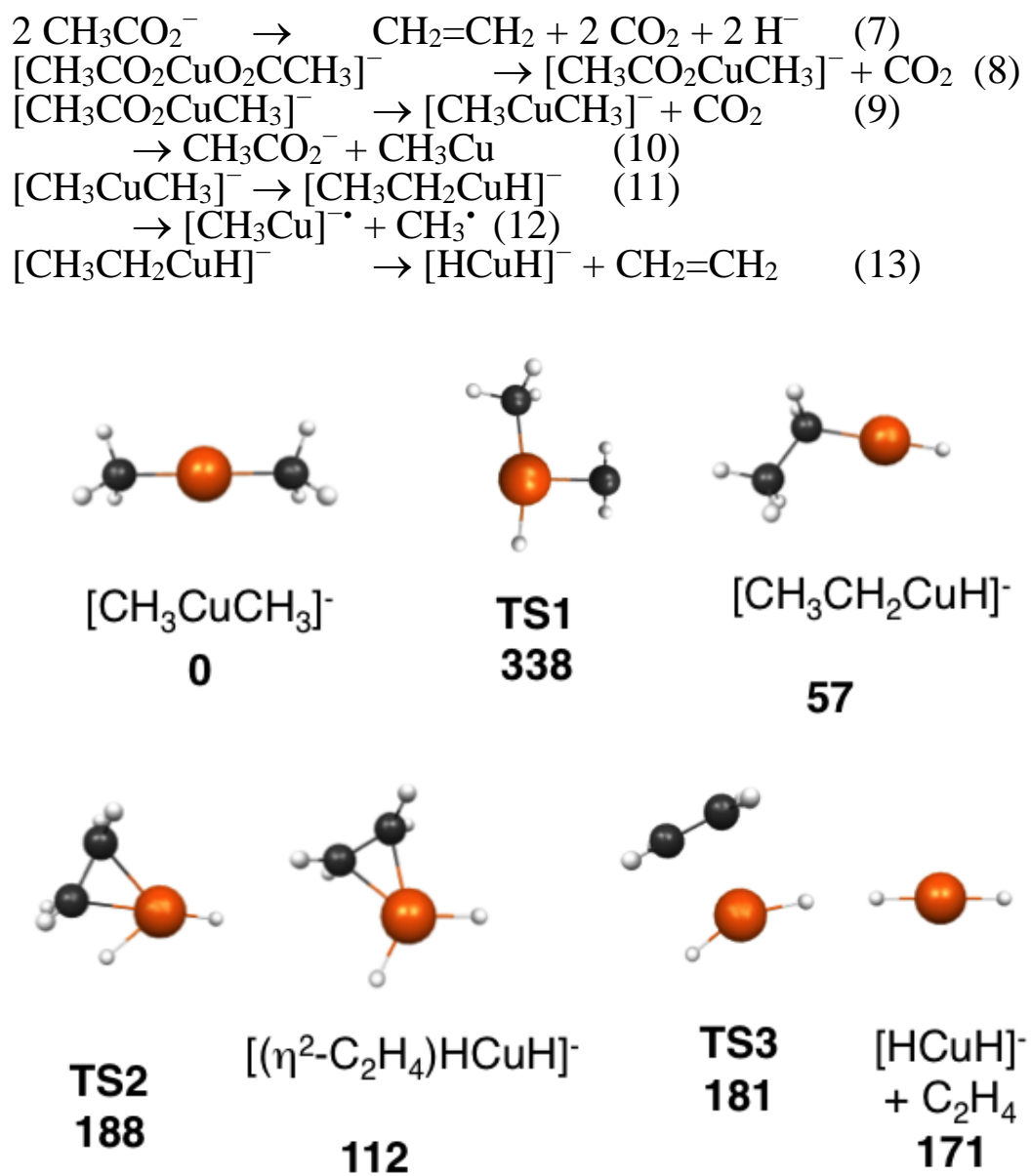

Figure 3. DFT calculated species associated with the 1,2-dyotropic rearrangement (eq. 11) of $\left[\mathrm{CH}_{3} \mathrm{CuCH}_{3}\right]^{-}$followed by the subsequent $\beta$-hydride elimination reaction (eq. 13). Energies are in $\mathrm{kJ} \mathrm{mol}^{-1}$.

This article is protected by copyright. All rights reserved. 


\section{Glaser like coupling of two acetylinic carboxylate ligands}

In a similar fashion, by exploring the sequential gas-phase unimolecular reactions of mononuclear and dinuclear cobalt mixed chloride/carboxylate anions, we have discovered a cobalt-promoted Glaser-like decarboxylative $\mathrm{C}-\mathrm{C}$ bond coupling of alkynyl carboxylic acids (eq. 14, R = H, Me and Ph) (Leeming et al., 2014). Double decarboxylation (eqs 15 and 16) of the cobalt anions, $\left[\mathrm{Co}_{\mathrm{x}} \mathrm{Cl}_{\mathrm{y}}\left(\mathrm{O}_{2} \mathrm{CC} \equiv \mathrm{CR}\right)_{2}\right]^{-}$(where: $\mathrm{x}$ $=\mathrm{y}=1$; or $\mathrm{x}=2$ and $\mathrm{y}=3$ ), results in the formation of two acetylide ligands, which can then undergo Glaser-like reductive elimination (Glaser, 1869; Siemsen et al., 2000). Note that unlike the dehydro decarboxylative coupling reaction (eq. 7), in which the $\mathrm{Cu}$ centre maintains its +1 oxidation state in the last step (eq. 13), here the decarboxylative coupling reaction delivers two electrons (eq. 14), which means that the Co centre(s) are reduced in the last step (eq. 17). In the case of the mononuclear anions, $\left[\mathrm{CoCl}(\mathrm{C} \equiv \mathrm{CR})_{2}\right]^{-}$, the formal oxidation state of the Co atom changes from +2 to 0 , whereas in the case of the the binuclear anions, $\left[\mathrm{Co}_{2} \mathrm{Cl}_{3}(\mathrm{C} \equiv \mathrm{CR})_{2}\right]^{-}$, the formal oxidation state of each Co atom changes from +2 to +1 . The dinuclear cobalt chloride anions were found to be superior at promoting both decarboxylation steps (eqs. 15 and 16) as well as the reductive-elimination coupling step (eq. 17), and the observed order of reactivity of $\mathrm{R}$ was found to be: $\mathrm{Ph}>\mathrm{Me}>\mathrm{H}$.

$$
\begin{aligned}
& 2 \mathrm{RC} \equiv \mathrm{CCO}_{2}^{-} \rightarrow \quad(\mathrm{RC} \equiv \mathrm{C})_{2}+2 \mathrm{CO}_{2}+2 \mathrm{e}^{-} \quad(14) \\
& {\left[\mathrm{Co}_{\mathrm{x}} \mathrm{Cl} l_{\mathrm{y}}\left(\mathrm{O}_{2} \mathrm{CC} \equiv \mathrm{CR}\right)_{2}\right]^{-} \quad \rightarrow \quad\left[\mathrm{Co}_{\mathrm{x}} \mathrm{Cl}_{\mathrm{y}}\left(\mathrm{O}_{2} \mathrm{CC} \equiv \mathrm{CR}\right)(\mathrm{C} \equiv \mathrm{CR})\right]^{-}+\mathrm{CO}_{2}} \\
& {\left[\mathrm{Co}_{\mathrm{x}} \mathrm{Cl} \mathrm{y}_{\mathrm{y}}\left(\mathrm{O}_{2} \mathrm{CC} \equiv \mathrm{CR}\right)(\mathrm{C} \equiv \mathrm{CR})\right]^{-} \quad \rightarrow \quad\left[\mathrm{Co}_{\mathrm{x}} \mathrm{Cl} l_{\mathrm{y}}(\mathrm{C} \equiv \mathrm{CR})_{2}\right]^{-}+\mathrm{CO}_{2}} \\
& {\left[\mathrm{Co}_{\mathrm{x}} \mathrm{Cl} l_{\mathrm{y}}(\mathrm{C} \equiv \mathrm{CR})_{2}\right]^{-} \rightarrow \quad \rightarrow \quad\left[\mathrm{Co}_{\mathrm{x}} \mathrm{Cl}_{\mathrm{y}}\right]^{-}+(\mathrm{RC} \equiv \mathrm{C})_{2}(17)}
\end{aligned}
$$

This article is protected by copyright. All rights reserved. 
Bimolecular coupling reactions of an organic ligand formed via decarboxylation and an organic substrate.

\section{Reactions with alkyl iodide and allyl iodide}

The reactions of coinage metal organometallates with methyl iodide and allyl iodide have been examined using a combination of ion trap mass spectrometry experiments and DFT calculations. The metal centre plays a key role in $\mathrm{C}-\mathrm{C}$ bond coupling, with dimethyl cuprate $\left[\mathrm{CH}_{3} \mathrm{CuCH}_{3}\right]^{-}$, reacting via cross-coupling (eq. 18), which contrasts with the Ag and Au congeners, which are unreactive (Rijs et al., 2010; James\&O'Hair, 2004). DFT calculations on a range of mechanisms found that this reaction proceeds via oxidative addition (OA) followed by reductive elimination (RE) as shown in Scheme 18. The enhanced reactivity of copper is due to the better match between the $\mathrm{HOMO}$ of $\left[\mathrm{CH}_{3} \mathrm{CuCH}_{3}\right]^{-}$and the LUMO of $\mathrm{CH}_{3} \mathrm{I}$.

$$
\left[\mathrm{CH}_{3} \mathrm{CuCH}_{3}\right]^{-}+\mathrm{CH}_{3} \mathrm{I} \quad \rightarrow\left[\mathrm{CH}_{3} \mathrm{CuI}\right]^{-}+\mathrm{CH}_{3} \mathrm{CH}_{3}
$$

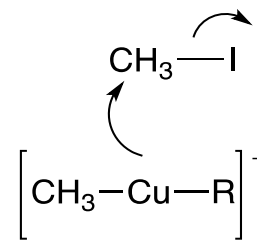

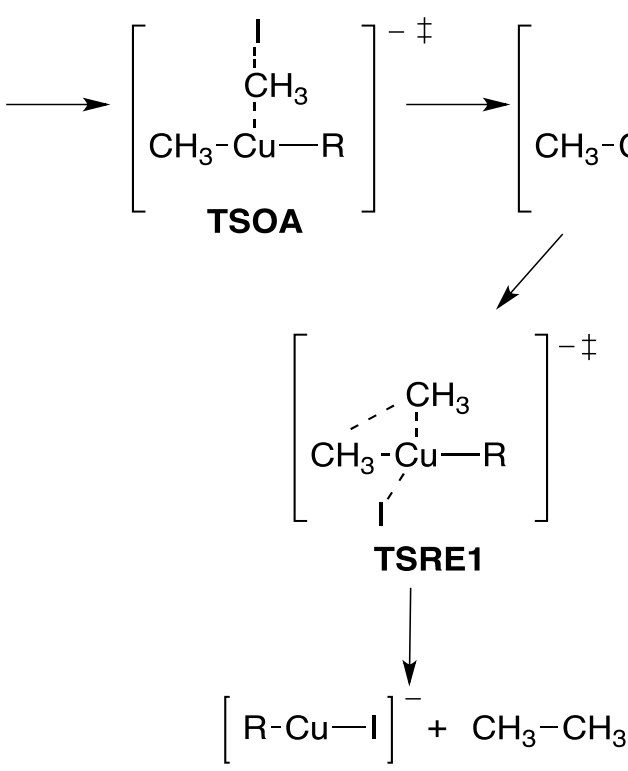

(17)

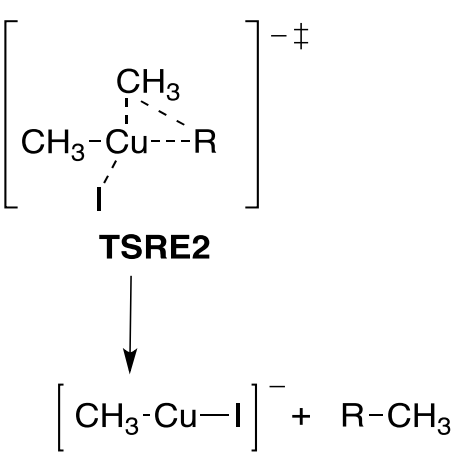

(18)

Scheme 18. OA/RE mechanism for the competition between $\mathrm{CH}_{3} \mathrm{CH}_{3}$ formation (reaction 17) and $\mathrm{RCH}_{3}$ formation (reaction 18) in the coupling reactions of $\left[\mathrm{CH}_{3} \mathrm{CuR}\right]^{-}$ with methyl iodide.

This article is protected by copyright. All rights reserved. 
Apart from the influence of the metal centre, ligand effects were probed by examining the reactions of methyl iodide with $\left[\mathrm{CH}_{3} \mathrm{CuR}\right]^{-}$(where $\mathrm{R}=$ organyl or hydride ligands) (Rijs et al., 2014). The selectivity and reactivity were examined via branching ratios of eqs 19 and 20 and the reaction kinetics.

$$
\begin{aligned}
{\left[\mathrm{CH}_{3} \mathrm{CuR}\right]^{-}+\mathrm{CH}_{3} \mathrm{I} } & \rightarrow[\mathrm{RCuI}]^{-}+\mathrm{CH}_{3} \mathrm{CH}_{3} \\
& \rightarrow\left[\mathrm{CH}_{3} \mathrm{CuI}\right]^{-}+\mathrm{RCH}_{3}
\end{aligned}
$$

It was found that alkyl R groups exhibited similar reactivity, while bulkier and less saturated groups resulted in lower rates of reactivity. $\left[\mathrm{CH}_{3} \mathrm{CuH}\right]^{-}$was found to be eight times more reactive than $\left[\mathrm{CH}_{3} \mathrm{CuCH}_{3}\right]^{-}$, highlighting the higher nucleophilicity of copper hydrides. While the selectivity is controlled by the reductive elimination (TSRE1 versus TSRE2, Scheme 18), the reactivity is kinetically controlled by the oxidative addition step (TSOA, Scheme 18), which is determined largely by the HOMO energy of the complex.

Allylation is mechanistically more complex than methylation, as revealed in a study of the reactions of $\left[\mathrm{CH}_{3} \mathrm{MCH}_{3}\right]^{-}(\mathrm{M}=\mathrm{Cu}, \mathrm{Ag}$ and $\mathrm{Au})$ with allyl iodide. These reactions can proceed via cross-coupling (eq. 21 and 22) in competition with homocoupling (eq. 23 and 24) and there are a range of mechanisms that can operate (Scheme 19) (Rijs et al., 2012).

$$
\begin{aligned}
{\left[\mathrm{CH}_{3} \mathrm{MCH}_{3}\right]^{-}+\mathrm{C}_{3} \mathrm{H}_{5} \mathrm{I} } & \rightarrow\left[\mathrm{CH}_{3} \mathrm{MI}^{-}+\mathrm{C}_{3} \mathrm{H}_{5} \mathrm{CH}_{3}\right. \\
& \rightarrow \mathrm{I}^{-}+\left[\mathrm{CH}_{3} \mathrm{M}\right]+\mathrm{C}_{3} \mathrm{H}_{5} \mathrm{CH}_{3} \\
& \rightarrow\left[\mathrm{C}_{3} \mathrm{H}_{5} \mathrm{MI}\right]^{-}+\mathrm{CH}_{3} \mathrm{CH}_{3}
\end{aligned}
$$

This article is protected by copyright. All rights reserved. 
$\left[\mathrm{CH}_{3} \mathrm{CuCH}_{3}\right]^{-}$was found to react with allyl iodide with a reaction efficiency of $6.6 \%$ of the collision rate. The ionic products detected, together with their branching ratios (expressed as a \%), are as follows: $\mathrm{I}^{-}(75 \%)$; the cross-coupling product, $\left[\mathrm{CH}_{3} \mathrm{CuI}\right]^{-}$ (eq. 21, 24\%); and the homo-coupling product, $\left[\mathrm{C}_{3} \mathrm{H}_{5} \mathrm{CuI}\right]^{-}$(eq. 23, 1\%). DFT calculations reveal that both OA/RE mechanisms (paths B and C of Scheme 19) are competitive, but that only the one proceeding via the $\pi$-allyl intermediate (path B) gives rise to cross coupling (eq 23). $\left[\mathrm{CH}_{3} \mathrm{AgCH}_{3}\right]^{-}$and $\left[\mathrm{CH}_{3} \mathrm{AuCH}_{3}\right]^{-}$reacted substantially slower with allyl iodide (reaction efficiencies of $0.028 \%$ and $0.072 \%$ ). The ionic products detected for $\left[\mathrm{CH}_{3} \mathrm{AgCH}_{3}\right]^{-}$were $\mathrm{I}^{-}(19 \%)$ and $\left[\mathrm{CH}_{3} \mathrm{AgI}\right]^{-}(81 \%)$, while for $\left[\mathrm{CH}_{3} \mathrm{AuCH}_{3}\right]^{-}$only $\mathrm{I}^{-}$was detected. DFT calculations suggest that the kinetically most probable pathway for $\left[\mathrm{CH}_{3} \mathrm{AgCH}_{3}\right]^{-}$is the $\mathrm{S}_{\mathrm{N}} 2$ reaction (path $\mathrm{A}$, Scheme 19), consistent with no homo-coupling product, $\left[\mathrm{C}_{3} \mathrm{H}_{5} \mathrm{AgI}\right]^{-}$, being observed in the experiments. In the case of $\left[\mathrm{CH}_{3} \mathrm{AuCH}_{3}\right]^{-}$, the DFT calculations suggest that $\mathrm{C}-\mathrm{C}$ coupling reaction is kinetically unviable, with $\mathrm{I}^{-}$predicted to be formed along with a stable $\mathrm{Au}(\mathrm{III}) \eta^{3}$-allyl complex. Overall, the gas-phase results highlight that organocuprates are superior reagents in allylic substitution reactions.

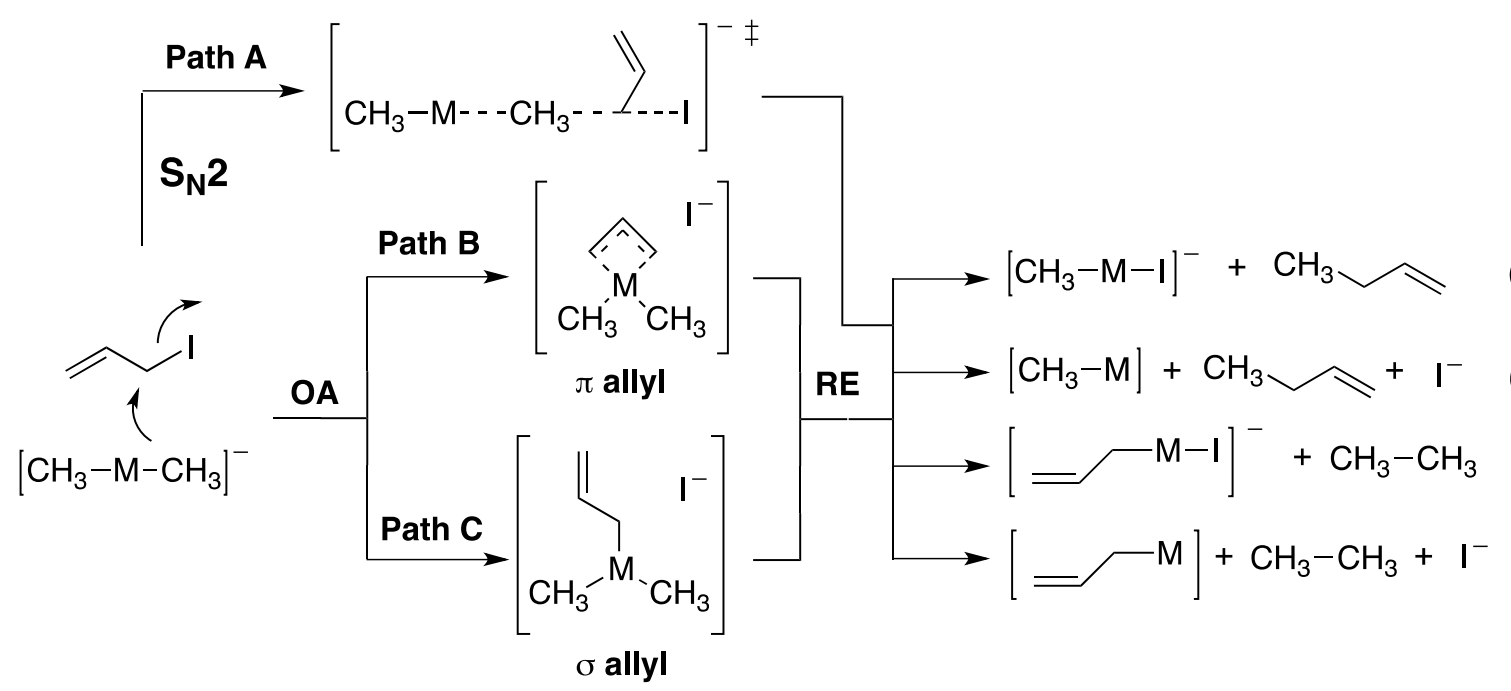

This article is protected by copyright. All rights reserved. 
Scheme 19. $\mathrm{S}_{\mathrm{N}} 2$ versus $\mathrm{OA} / \mathrm{RE}$ (via $\pi$ or $\sigma$ allyl intermediates) mechanisms for $\mathrm{C}-\mathrm{C}$ bond coupling of $\left[\mathrm{CH}_{3} \mathrm{MCH}_{3}\right]^{-}$with allyl iodide. Only OA/RE allows competition between cross coupling (eqs. 21 and 22) and homo coupling (eqs. 23 and 24).

Allylation was also explored for the bimetallic and heterobimetallic cations $\left[\mathrm{RAg}_{2}\right]^{+}$, $(\mathrm{R}=\mathrm{Me}, \mathrm{MeC} \equiv \mathrm{C}$ and $\mathrm{PhC} \equiv \mathrm{C}),\left[\mathrm{MeCu}_{2}\right]^{+}$and $[\mathrm{MeAgCu}]^{+}$(Khairallah et al., 2009; Khairallah et al., 2013). The bimetallic species were found to react via C-C bond formation (eq. 25), with DFT studies predicting a slight preference for reaction at the copper centre in $[\mathrm{MeAgCu}]^{+}$. In the case of the silver acetylides, a small amount of the C-C bond coupled product bound to a silver cation was observed (eq. 26). Mass selection of this ion (for $\mathrm{R}=\mathrm{PhC} \equiv \mathrm{C}$ ) and comparison of its $\mathrm{CID}$ spectrum to an "authentic" sample of $\left[\left(\mathrm{PhC} \equiv \mathrm{CCH}_{2} \mathrm{CH}=\mathrm{CH}_{2}\right) \mathrm{Ag}\right]^{+}$, confirmed that cross coupling had occurred.

$$
\begin{array}{r}
{\left[\mathrm{RAg}_{2}\right]^{+}+\mathrm{C}_{3} \mathrm{H}_{5} \mathrm{I} \longrightarrow\left[\mathrm{IAg}_{2}\right]^{+}+\mathrm{C}_{3} \mathrm{H}_{5} \mathrm{R}} \\
\rightarrow\left[\mathrm{C}_{3} \mathrm{H}_{5} \mathrm{R}+\mathrm{Ag}\right]^{+}+\mathrm{AgI}
\end{array}
$$

Reaction of the methyl palladalactone $\left[(\mathrm{Me}) \mathrm{Pd}\left(\mathrm{CH}_{2} \mathrm{CO}_{2}\right)\right]^{-}$with allyl iodide proceeds via the formation of an observable $\mathrm{Pd}(\mathrm{IV})$ intermediate, $\left[(\mathrm{Me})(\mathrm{I})\left(\mathrm{CH}_{2} \mathrm{CHCH}_{2}\right) \mathrm{Pd}\left(\mathrm{CH}_{2} \mathrm{CO}_{2}\right)\right]^{-}$(eq. 27), (Vikse et al., 2012) which also decomposes through: allylation via RE (forming ions at $m / z 291\left[(\mathrm{I}) \mathrm{Pd}\left(\mathrm{CH}_{2} \mathrm{CO}_{2}\right)\right]^{-}$eq. 28, or $m / z 127, \mathrm{I}^{-}$eq. 29); homo-coupling via RE of propionate (eq. 30). Another major side-product is formed via iodide atom abstraction to form $\mathrm{m} / \mathrm{z} 306$ $\left[(\mathrm{Me})(\mathrm{I}) \mathrm{Pd}\left(\mathrm{CH}_{2} \mathrm{CO}_{2}\right)\right]^{-}$(eq. 31).

$\left[(\mathrm{Me}) \mathrm{Pd}\left(\mathrm{CH}_{2} \mathrm{CO}_{2}\right)\right]^{-}+\mathrm{C}_{3} \mathrm{H}_{5} \mathrm{I} \rightarrow\left[(\mathrm{Me})(\mathrm{I})\left(\mathrm{CH}_{2} \mathrm{CHCH}_{2}\right) \mathrm{Pd}\left(\mathrm{CH}_{2} \mathrm{CO}_{2}\right)\right]^{-}$

$\left[(\mathrm{Me})(\mathrm{I})\left(\mathrm{CH}_{2} \mathrm{CHCH}_{2}\right) \mathrm{Pd}\left(\mathrm{CH}_{2} \mathrm{CO}_{2}\right)\right]^{-} \rightarrow\left[(\mathrm{I}) \mathrm{Pd}\left(\mathrm{CH}_{2} \mathrm{CO}_{2}\right)\right]^{-}+\mathrm{C}_{3} \mathrm{H}_{5} \mathrm{CH}_{3}$

This article is protected by copyright. All rights reserved. 


$$
\begin{aligned}
& \rightarrow \mathrm{I}^{-}+\left[\mathrm{Pd}\left(\mathrm{CH}_{2} \mathrm{CO}_{2}\right)\right]^{-}+\mathrm{C}_{3} \mathrm{H}_{5} \mathrm{CH}_{3} \\
& \rightarrow \mathrm{CH}_{3} \mathrm{CH}_{2} \mathrm{CO}_{2}^{-}+\left[(\mathrm{I}) \mathrm{PdC}_{3} \mathrm{H}_{5}\right]
\end{aligned}
$$

$\left[(\mathrm{Me}) \mathrm{Pd}\left(\mathrm{CH}_{2} \mathrm{CO}_{2}\right)\right]^{-}+\mathrm{C}_{3} \mathrm{H}_{5} \mathrm{I} \rightarrow\left[(\mathrm{Me})(\mathrm{I}) \mathrm{Pd}\left(\mathrm{CH}_{2} \mathrm{CO}_{2}\right)\right]^{-\bullet}+\mathrm{CH}_{2} \mathrm{CHCH}_{2}{ }^{*}$

When the leaving group is a carboxylate, these allylic allylation reactions can be made catalytic, which is the subject of section VIII below.

\section{Reaction with $\mathrm{CS}_{2}$}

The ion-molecule reactions between $\left[\mathrm{CH}_{3} \mathrm{CuCH}_{3}\right]^{-}$, formed via double decarboxylation of $\left[\mathrm{CH}_{3} \mathrm{CO}_{2} \mathrm{CuO}_{2} \mathrm{CCH}_{3}\right]^{-}$(eqs 8 and 9), and carbon disulfide were examined in an ion trap mass spectrometer ( $\mathrm{Li}$ et al., 2015). $\left[\mathrm{CH}_{3} \mathrm{CuCH}_{3}\right]^{-}$reacts with $\mathrm{CS}_{2}$ with a reaction efficiency of $0.8 \%$ of the collision rate to yield: the adduct, $\left[\mathrm{CH}_{3} \mathrm{CuS}_{2} \mathrm{CCH}_{3}\right]^{-}$(eq. 32, 77.5\%), as well as $\mathrm{CH}_{3} \mathrm{CS}_{2}^{-}$(eq. 33, 22.5\%). CID of the adduct $\left[\mathrm{CH}_{3} \mathrm{CuS}_{2} \mathrm{CCH}_{3}\right]^{-}$gives $\mathrm{CH}_{3} \mathrm{CS}_{2}{ }^{-}$as the major product (eq. 34), with a small amount of $\left[\mathrm{CuS}_{2} \mathrm{CCH}_{2}\right]^{-}$being formed via loss of methane (eq. 35). DFT calculations reveal that: (i) $\left[\mathrm{CH}_{3} \mathrm{CuCH}_{3}\right]^{-}$ reacts via oxidative addition to form a $\mathrm{Cu}(\mathrm{III})$ intermediate, followed by reductive elimination of $\mathrm{CH}_{3} \mathrm{CS}_{2}^{-}$, which is captured by $\mathrm{Cu}$ to form $\left[\mathrm{CH}_{3} \mathrm{CuS}_{2} \mathrm{CCH}_{3}\right]^{-}$. This energetic adduct can fragment via loss of $\mathrm{CH}_{3} \mathrm{CS}_{2}^{-}$(eq. 33) or can be collisionally cooled by the helium bath gas used in the experiments (eq. 32). (ii) Loss of $\mathrm{CH}_{4}$ from $\left[\mathrm{CH}_{3} \mathrm{CuS}_{2} \mathrm{CCH}_{3}\right]^{-}$also involves a $\mathrm{Cu}(\mathrm{III})$ intermediate and results in formation of the metaladithiolactone, $\left[\mathrm{Cu}\left(\mathrm{CH}_{2} \mathrm{CS}_{2}\right)\right]^{-}$(eq. 35). The copper complex $\left[(\mathrm{Bphen}) \mathrm{Cu}\left(\mathrm{O}_{2} \mathrm{CC}_{6} \mathrm{H}_{5}\right)\right]^{2-} \quad$ (Bphen $=$ bathophenanthroline) also undergoes decarboxylation and the resultant organometallic complex, $\left[(\mathrm{Bphen}) \mathrm{Cu}\left(\mathrm{C}_{6} \mathrm{H}_{5}\right)\right]^{2-}$, reacts with $\mathrm{CS}_{2}$ to form $\left[(\mathrm{Bphen}) \mathrm{Cu}\left(\mathrm{S}_{2} \mathrm{CC}_{6} \mathrm{H}_{5}\right)\right]^{2-}(\mathrm{Yang}$, Canty, O’Hair, 2020).

This article is protected by copyright. All rights reserved. 


$$
\begin{aligned}
& {\left[\mathrm{CH}_{3} \mathrm{CuCH}_{3}\right]^{-}+\mathrm{CS}_{2} } \rightarrow \quad\left[\mathrm{CH}_{3} \mathrm{CuS}_{2} \mathrm{CCH}_{3}\right]^{-} \\
& \rightarrow \quad \mathrm{CH}_{3} \mathrm{CS}_{2}^{-}+\left[\mathrm{CH}_{3} \mathrm{Cu}\right](33) \\
& {\left[\mathrm{CH}_{3} \mathrm{CuS}_{2} \mathrm{CCH}_{3}\right]^{-} } \rightarrow \quad \mathrm{CH}_{3} \mathrm{CS}_{2}^{-}+\left[\mathrm{CH}_{3} \mathrm{Cu}\right] \\
& \rightarrow \quad\left[\mathrm{Cu}\left(\mathrm{CH}_{2} \mathrm{CS}_{2}\right)\right]^{-}+\mathrm{CH}_{4}
\end{aligned}
$$

\section{Comparisons with condensed-phase systems}

\section{Unimolecular coupling reactions of two organic ligands formed via double decarboxylation.}

Organometallics are known to undergo a range of thermally induced unimolecular reactions in the condensed phase including bond homolysis, reductive elimination reactions and various bond activation processes including $\beta$-hydride elimination (Hashimoto\& Nakano, 1966; Yamamoto et al., 1967; Whitesides et al., 1970; Whitesides et al., 1972; Whitesides et al., 1974; House\& DuBose, 1975; Miyashita et al., 1977; Åkermark\& Ljungqvist, 1979; Bergbreiter\& Lynch, 1981; Shutova et al., 1996; Ruhland, 2012). By studying these reactions in the gas phase using CID experiments and DFT calculations, we have been able to observe related reactions as well as discover new types of coupling reactions (eqs 7 and 14). Although there are numerous examples of reductive elimination of two coordinated ligands (cf eq. 17) (Astruc, 2007), the dehydrocoupling of $\left[\mathrm{CH}_{3} \mathrm{CuCH}_{3}\right]^{-}$is unusual. This 1,2-dyotropic rearrangement is, however, related to 1,2-alkyl shift reactions of organometallic compounds, which typically involve halides as migrating species instead of hydride (Aggarwal, 2006).

This article is protected by copyright. All rights reserved. 
The cobalt-mediated decarboxylative $\mathrm{C}-\mathrm{C}$ bond coupling of alkynyl carboxylic acids is related to a solution-phase report on the dual metal catalytic system (Scheme 20) (Park et al., 2011). One difference is that the two metals are required in solution: a silver salt is used in excess to promote decarboxylation, which is followed a transmetallation reaction to palladium and reductive elimination.

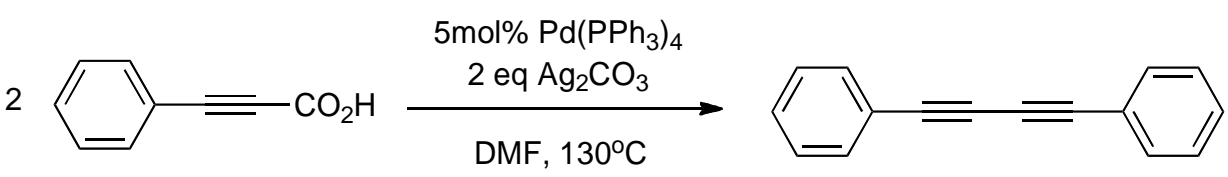

Scheme 20: Example of decarboxylative C-C bond coupling of alkynyl carboxylic acids (Park et al., 2011).

Bimolecular coupling reactions of an organic ligand formed via decarboxylation and an organic substrate.

The cross coupling reactions of organometallic reagents and organic substrates have been widely studied and have become a cornerstone in metal-catalyzed $\mathrm{C}-\mathrm{C}$ bond forming reactions used in organic synthesis. Indeed, the use of cuprates (Krause, 2002; Rappoport et al., 2009; Yoshikai\&Nakamura, 2012) in cross coupling reactions with alkylhalides is a textbook reaction (McMurry, 2008). There has been considerable interest in developing decarboxylative versions of these catalytic reactions in which carboxylic acids are used as substrates (Goossen et al., 2008; Goossen et al., 2008; Goossen et al., 2010; Rodriguez\&Goossen, 2011; Shang\& Liu, 2011; Dzik et al., 2012; Cornella\&Larrosa, 2012; Goossen\&Goossen, 2013; Miao\&Ge, 2014; Li et al., 2016; Satoh\&Miura, 2016; Patra\&Maiti, 2017; Perry\& Larrosa, 2017; Sandfort et al., 2017; Campeau\& Hazari, 2019; Daley\& Topczewski, 2020; Moon\&Lundgren, 2020). The solution-phase equivalent of the metal-mediated decarboxylative conversion of a carboxylate to a dithiocarboxylate discussed above (eqs 9, 32 and 33), however, appears

This article is protected by copyright. All rights reserved. 
to be unprecedented in the literature. The only examples of such transformations are metal-free and involve zwitterionic substrates where the decarboxylated intermediate is an ylid (Scheme 21) (Katritzky et al., 1985; Schmidt et al., 2008).

(A)<smiles></smiles>
$\mathrm{R}=\mathrm{Me}$ and $\mathrm{Ph}$

(B)

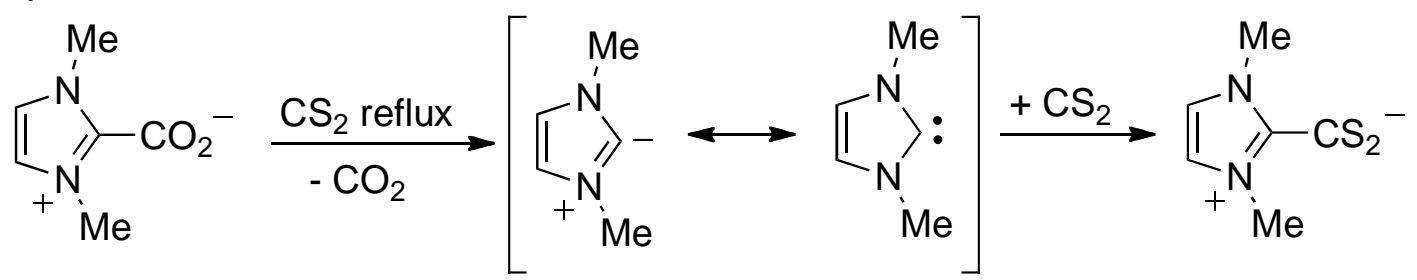

Scheme 21: Examples of the transformation of a carboxylate to a dithiocarboxylate (Katritzky et al., 1985; Schmidt et al., 2008).

\section{Perspectives}

A key aspect of gas-phase studies is that a wide range of organometallic ions, $\left[(\mathrm{L})_{n} \mathrm{M}(\mathrm{R})\right]^{+/-}$, can be formed via decarboxylation of $\left[(\mathrm{L})_{n} \mathrm{M}\left(\mathrm{O}_{2} \mathrm{CR}\right)\right]^{+-}$(eq. 3), thus allowing their unimolecular and bimolecular reactions to be surveyed. New modes of sequential reactivity have thereby been discovered, some which have no solution-phase precedence, but are worthy of following up in solution. For example, while the metalcatalyzed decarboxylative conversion of carboxylic acids to dithiocarboxylic acids (eq. 36) have not been reported in solution, there is literature precedence for at least two of the three elementary steps of the potential catalytic cycle shown in Scheme 22. Thus step 1 has been widely studied for a range of metals, including copper (Deacon, 1970, Deacon et al., 1986). Insertion of $\mathrm{CS}_{2}$ into an organometallic $\mathrm{M}-\mathrm{R}$ bond is also well This article is protected by copyright. All rights reserved. 
established, including for organocopper compounds (Westmijze et al., 1979; Camus et al., 1980; Lanfredi et al., 1983; Verkruijsse\& Brandsma, 1987; Camus et al., 1990; Pandey, 1995). In contrast, the remaining metathesis reaction (step 3) does not appear to have been studied. The successful metal-promoted extrusion of $\mathrm{CO}_{2}$ followed by insertion of an isoelectronic heterocumulene such as $\mathrm{CS}_{2}$ encouraged us to embark on a series of studies that utilized an integrated mechanisms-based approach to develop related extrusion-insertion (ExIn) reactions for the synthesis of amides, thioamides and amidines. These studies are discussed in detail in section IX below.

$$
\mathrm{RCO}_{2} \mathrm{H}+\mathrm{CS}_{2} \rightarrow \quad \mathrm{RCS}_{2} \mathrm{H}+\mathrm{CO}_{2}
$$

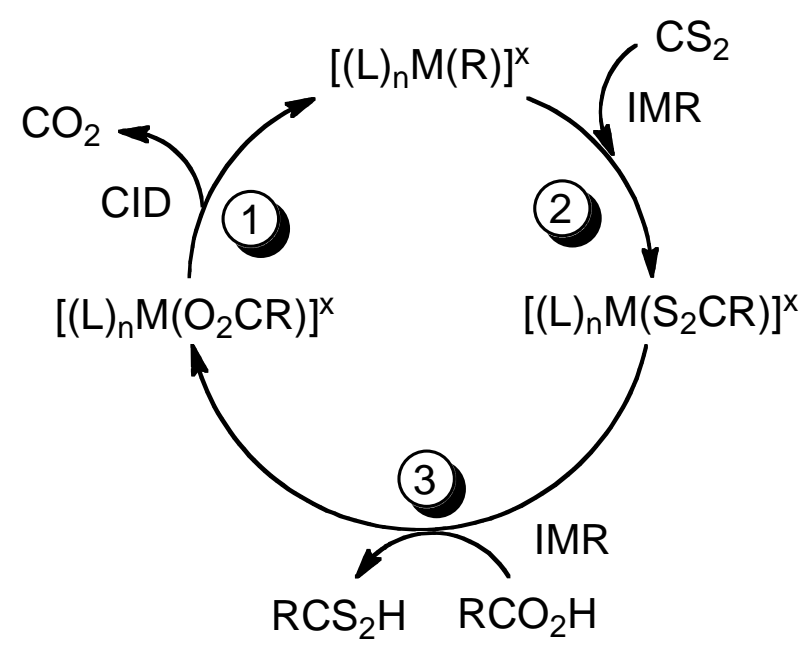

Scheme 22: Possible three step catalytic cycle for the metal-catalyzed transformation of a carboxylic acid to a dithiocarboxylic acid.

\section{Decarboxylative C-C bond coupling of carboxylic acid esters}

\section{A. Definition of the catalytic problem}

The metal-catalyzed decarboxylative cross-coupling reactions of carboxylic acid esters are highly desirable as they represent a unique class of single-substrate reactions that exhibit high atom economy since both $\mathrm{R}^{1}$ and $\mathrm{R}^{2}$ groups are used, and only $\mathrm{CO}_{2}$ is produced as a waste by-product (eq. 37). As a consequence, this class of reactions has This article is protected by copyright. All rights reserved. 
received considerable recent attention from the organic chemistry community (Sherden et al., 2009; Weaver et al., 2011; Keith et al., 2012; Li et al., 2012). As noted in a review (O'Hair, 2015), the scope of the reaction (eq. 37) has tended to be limited to carboxylic acid esters which can form stabilized anions $\left(\mathrm{R}^{1}\right)$ and cations $\left(\mathrm{R}^{2}\right)$.

$$
\mathrm{R}^{1} \mathrm{CO}_{2} \mathrm{R}^{2} \quad \rightarrow \quad \mathrm{R}^{1}-\mathrm{R}^{2}+\mathrm{CO}_{2}
$$

\section{B. Insights from gas-phase studies}

Since examples of the metal-catalyzed gas-phase decarboxylative C-C bond coupling reactions of allyl acetate have been the subject of a review (O'Hair, 2015), they are only briefly discussed here. This class of reactions is related to protodecarboxylation as it proceeds via two discrete steps (cf Figure 1 and Scheme 23). Whatever the precise mechanism involved in the allylic alkylation step (Step 1 of Scheme 23), it is informative to compare the DFT-calculated energetics of the highest transition state as a function of the metal catalyst (Table 2).

Table 2: Key energetics in $\mathrm{kJ} \mathrm{mol}^{-1}$ for step 1 of the gas-phase transition metalcatalyzed decarboxylative alkylation of allyl acetate (Scheme 23) and the lowest energy mechanism for $\mathrm{C}-\mathrm{C}$ bond coupling. Experimentally derived reaction efficiencies for $\mathrm{C}$ $\mathrm{C}$ bond coupling.

\begin{tabular}{|l|l|l|l|l|}
\hline $\begin{array}{l}\text { Organometallic } \\
\text { catalyst }\end{array}$ & $\Delta \mathbf{H}$ TS1 & $\Delta \mathbf{H}$ step1 & $\begin{array}{l}\text { Mechanism from DFT } \\
\text { calculations (a) }\end{array}$ & $\begin{array}{l}\text { C-C bond } \\
\text { coupling } \\
\text { reaction } \\
\text { efficiency }\end{array}$ \\
\hline$\left[\mathrm{CH}_{3} \mathrm{CuCH}_{3}\right]^{-(b)}$ & +26 & -203.8 & $\mathrm{OA} / \mathrm{RE}$ & $0.032 \%$ \\
\hline$\left[\mathrm{CH}_{3} \mathrm{Cu}_{2}\right]^{+(\mathrm{c})}$ & -132.2 & -80.1 & $\mathrm{OA} / \mathrm{RE}$ & $52.7 \%$ \\
\hline$\left[\mathrm{CH}_{3} \mathrm{CuAg}^{+(\mathrm{c})}\right.$ & -78.2 & -77.2 & $\mathrm{OA} / \mathrm{RE}$ & $1.2 \%$ \\
\hline$\left[\mathrm{CH}_{3} \mathrm{Ag}_{2}\right]^{+(\mathrm{c})}$ & -9.6 & -81.0 & $\mathrm{OA} / \mathrm{RE}$ & $0 \%$ \\
\hline
\end{tabular}

This article is protected by copyright. All rights reserved. 


\begin{tabular}{|l|l|l|l|l|}
\hline$\left[(\text { phen }) \mathrm{Ni}\left(\mathrm{CH}_{3}\right)\right]^{+(\mathrm{d})}$ & -106.3 & -231.0 & Insert. $/ \beta-O A c$ elim. & $47 \%$ \\
\hline$\left[(\text { phen }) \operatorname{Pd}\left(\mathrm{CH}_{3}\right)\right]^{+}(\mathrm{d})$ & -104.6 & -154.4 & Insert. $/ \beta-O A c$ elim. & $49 \%$ \\
\hline$\left[(\text { phen }) \operatorname{Pt}\left(\mathrm{CH}_{3}\right)\right]^{+(\mathrm{d})}$ & -112.1 & -184.1 & Insert. $/ \beta-O A c$ elim. & $2 \%$ \\
\hline
\end{tabular}

(a) OA/RE (Scheme 23b). Insert./ß-OAc elim. (Scheme 23c).

(b) Energetics calculated at the B3LYP/Def2-QZVP//B3LYP/SDD6-31+G(d) level of theory (Rijs\& O'Hair, 2012).

(c) Energetics calculated at the MO6/SDD6-31+G(d) level of theory (Al Sharif et al., 2013).

(d) Energetics calculated at the MO6/SDD6-31+G(d) level of theory (Woolley et al., 2014).

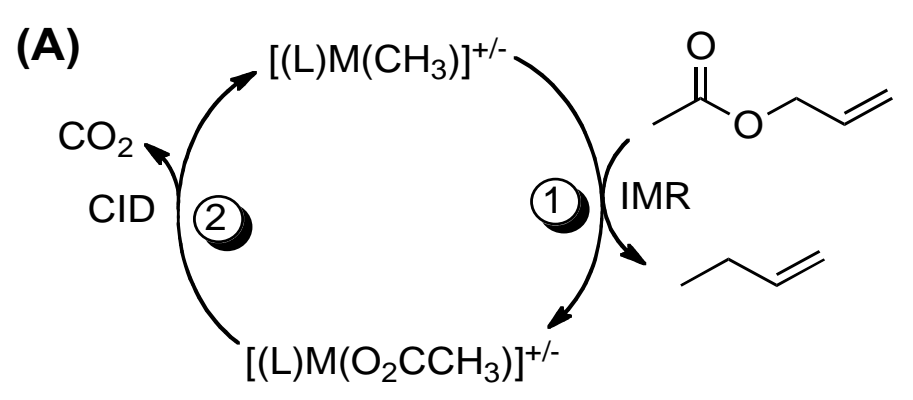
Catalysts examined:
$\left[\mathrm{CH}_{3} \mathrm{CuCH}_{3}\right]^{-}$
$\left[\mathrm{CH}_{3} \mathrm{Cu}_{2}\right]^{+}$,
$\left[\mathrm{CH}_{3} \mathrm{CuAg}\right]^{+}$,
$\left[\mathrm{CH}_{3} \mathrm{Ag}_{2}\right]^{+}$
$\left[(\text { phen }) \mathrm{Ni}\left(\mathrm{CH}_{3}\right)\right]^{+}$,
$\left[(\text { phen }) \mathrm{Pd}\left(\mathrm{CH}_{3}\right)\right]^{+}$,
$\left[(\text { phen }) \operatorname{Pt}\left(\mathrm{CH}_{3}\right)\right]^{+}$

(B)

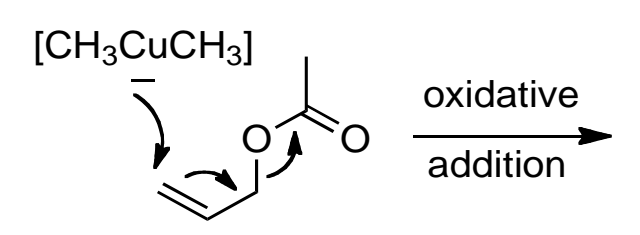

(C)<smiles>C=CCOC(=O)CC(C)(C)C(C)(C)C</smiles>

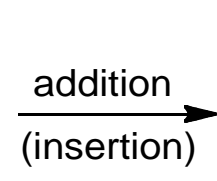<smiles>CCCC[C@H](C)C(C)C</smiles>

reductive

elimination<smiles>C=CCC</smiles>

+ catalyst

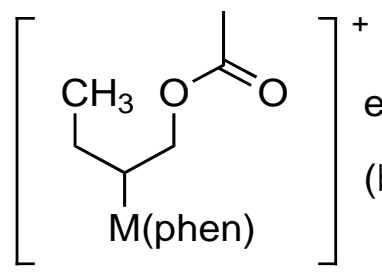

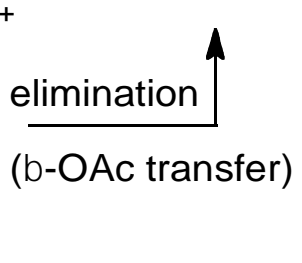

Scheme 23: (a) Two step catalytic cycle for decarboxylative $\mathrm{C}-\mathrm{C}$ bond coupling reactions of allyl acetate. Step 1 is the allylic alkylation step and the calculated energetics are given in Table 2. Step 2 is the decarboxylation reaction. (b) Oxidative addition/reductive elimination mechanism. (c) Insertion/ $\beta$-OAc elimination mechanism.

This article is protected by copyright. All rights reserved. 
The DFT calculations predict that this reaction is exothermic for all organometallic ions (Table 2, column 3). The energy of TS1 should be below that of the separated reactants for this reaction to occur under the near thermal conditions of ion-trap mass spectrometers (Gronert, 1998; Donald et al., 2013), which is the case for all organometallic ions (Table 1, column 2), except $\left[\mathrm{CH}_{3} \mathrm{CuCH}_{3}\right]^{-}$, which only reacts very slowly. Whether or not allylic alkylation occurs also depends on whether there are other, more competitive "off cycle" reactions. An examination of the last column of Table 2, which shows the experimental reaction efficiency for C-C bond coupling data and thus allows the ability of the catalysts to promote step 1 to be compared, reveals that the best catalysts are $\left[\mathrm{CH}_{3} \mathrm{Cu}_{2}\right]^{+},\left[(\text {phen }) \mathrm{Ni}\left(\mathrm{CH}_{3}\right)\right]^{+}$and $\left[(\text {phen }) \mathrm{Pd}\left(\mathrm{CH}_{3}\right)\right]^{+}$.

The metal carboxylate ionic product of allylic alkylation, $\left[(\mathrm{L}) \mathrm{M}\left(\mathrm{O}_{2} \mathrm{CCH}_{3}\right)\right]^{+/}$, is cooled back to room temperature via collisions with the helium bath gas. In order to be decarboxylated, it must be mass-selected and allowed to undergo an endothermic CID reaction in step 2. Although this step has been discussed above within the context of the protodecarboxylation reaction, it is worth noting that the same catalysts that work well for step 1, are also readily regenerated via decarboxylation.

\section{Comparisons with condensed-phase systems}

The decarboxylative cross-coupling reactions of carboxylic acid esters have been reviewed in terms of: their mechanistic features; the scope of the carboxylic acid ester substrates; and applications in total synthesis (Weaver et al., 2011). While several metal catalysts have been used, by far the most widely used metal-ligand combination has been $\operatorname{Pd}(0)$ with phosphine ligands. An attractive feature of these reactions is that they formally generate a nucleophilic carbon $\left(\mathrm{R}^{1}\right)$ and an electrophilic carbon $\left(\mathrm{R}^{2}\right)$ in situ, which helps explain the scope of the reaction, which has tended to require the formation

This article is protected by copyright. All rights reserved. 
of stabilized anions $\left(\mathrm{R}^{1}\right)$ and cations $\left(\mathrm{R}^{2}\right)$. Thus allyl and benzyl carboxylic acid esters have been widely used.

\section{Perspectives}

Metal-catalyzed allylation reactions exhibit a diverse range of metal-dependant mechanistic behaviour, and this holds true for step 1 of the metal-catalyzed decarboxylative cross-coupling of allyl acetate (Scheme 23): $\left[\mathrm{CH}_{3} \mathrm{CuCH}_{3}\right]^{-}$reacts via oxidative addition to form a $\pi$-allyl intermediate that then undergoes reductive elimination (Rijs\&O'Hair, 2012); $\left[\mathrm{CH}_{3} \mathrm{Cu}_{2}\right]^{+}$and $\left[\mathrm{CH}_{3} \mathrm{CuAg}\right]^{+}$react via oxidative addition involving both metal centers, followed by reductive elimination (Al Sharif et al., 2013); while $\left[(\text { phen }) \mathrm{M}\left(\mathrm{CH}_{3}\right)\right]^{+}$(where $\mathrm{M}=\mathrm{Ni}$, $\mathrm{Pd}$ and $\mathrm{Pt}$ ) react via insertion followed by $\beta$-OAc transfer (Woolley et al., 2014). Of all the catalysts studied to date, the organometallic cations $\left[\mathrm{CH}_{3} \mathrm{Cu}_{2}\right]^{+}$and $\left[(\text {phen }) \mathrm{Pd}\left(\mathrm{CH}_{3}\right)\right]^{+}$are the best catalysts for both steps of the catalytic cycle, while $\left[(\text { phen }) \mathrm{Ni}\left(\mathrm{CH}_{3}\right)\right]^{+}$is also a promising catalyst which suggests that related nickel catalysts should be explored in solution.

Metal-catalyzed decarboxylative alkylation reactions remain limited by the scope of carboxylic acid ester substrates that can be used. To date the solution-phase decarboxylation of alkyl carboxylates, $\mathrm{R}^{1} \mathrm{CO}_{2}^{-}$, has been a challenge due to the high basicities of the resultant alkyl anions, $\mathrm{R}^{1-}$. Tunge has reported the decarboxylative allylation of amino alkanoic carboxylic acid esters using a dual-catalyst system consisting of a palladium catalysis and an iridium photocatalyst (Scheme 24) (Lang et al., 2014). A key feature is that photochemical oxidation of the carboxylate anion gives a carboxylate radical, which is known to readily decarboxylate to generate an alkyl radical intermediate, which then undergoes allylation. This represents a promising new

This article is protected by copyright. All rights reserved. 
approach to extend the scope of carboxylic acid ester substrates that can be used in metal-catalyzed decarboxylative alkylation reactions.

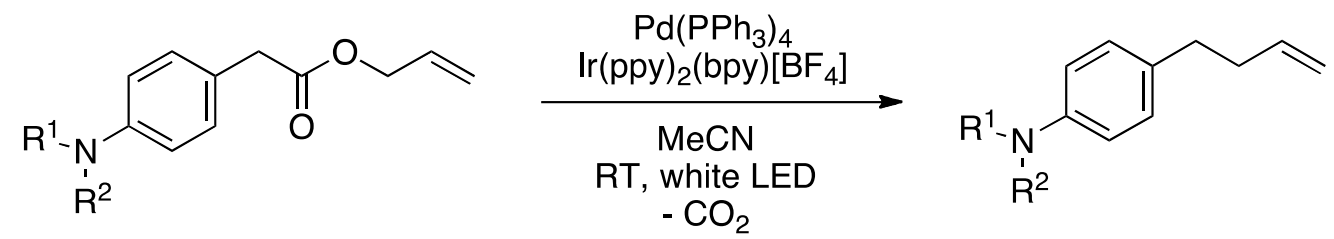

Scheme 24: Overcoming challenging decarboxylation reactions using a dual-metal photocatalysis approach (Lang et al., 2014).

IX. The potential role for integrated mechanistic studies to discover new catalysts and invent new reactions.

\section{A. Towards an integrated mechanistic approach in catalysis.}

Most advances in transition-metal (TM) catalysis have been achieved by trial-and-error, serendipitous discovery or through high-throughput screening (what MacMillan has described as "accelerated serendipity" (McNally et al., 2011)). As Perez-Temprano has noted in a recent review (Sanjosé-Orduna et al., 2019), "Surprisingly, one strategy that has received very limited attention, despite its potential to provoke a paradigm shift in terms of sustainability, is the rational design of chemical transformations based on knowledge-driven approaches. Mechanistic investigations are typically applied as an a posteriori tool, which focuses on understanding the reaction mechanism of successful transformations. " Based on the fact that the success or failure of a catalytic cycle depends on the performance of the reaction intermediates involved in each elementary step, she advocates for the use of key reaction intermediates as "knowledge building blocks". The value of gas-phase studies in unlocking fundamental information on the reaction intermediates associated with elementary step has long be recognised, but few studies have translated this knowledge to the design of new catalysts or catalytic processes. Here recent progress in two areas is reviewed.

This article is protected by copyright. All rights reserved. 


\section{B. Design of catalysts for the selective decomposition of formic acid.}

Deploying a reaction-mechanisms approach, where $\mathrm{MS}^{\mathrm{n}}$ experiments in an ion trap are blended with DFT calculations (O'Hair, 2006; O'Hair\&Rijs, 2015), new catalysts for the selective decarboxylation of formic acid have been designed (Scheme 25a,b)( Zavras et al., 2016; Zavras et al., 2016; Zavras et al., 2017; Krstić et al., 2018). This reaction is of considerable interest for the use of formic acid in hydrogen storage applications (Grasemann\&Laurenczy, 2012). Through a sequence of iterations in which different ligands and metal sites were evaluated, a series of ligated binuclear coinage metal hydride cationic catalysts were developed. In each case a two-step catalytic cycle operates (Scheme 25a) in which the metal hydride complex, 36, reacts in Step 1 with formic acid to liberate hydrogen and form a coordinated metal formate, $\mathbf{3 7}$, which in Step 2 liberates $\mathrm{CO}_{2}$ under conditions of CID. For the first generation catalysts, the best ligand for the silver hydride was 1,1-bis(diphenylphosphino)methane (dppm) to give complex 36a (Scheme 25b), and solution-phase studies confirmed the liberation of $\mathrm{H}_{2}$ and $\mathrm{CO}_{2}$ at a relatively low temperature of $65^{\circ} \mathrm{C}$ (Zavras et al., 2016). Although the stoichiometry of the solution-phase catalysts is unknown, subsequent gas-phase studies highlighted that tetranuclear silver hydride cluster complexes were unreactive towards formic acid (Zavras\& White\& O'Hair, 2016). The role of the metal centre was then assessed, where all possible homo and hetero coinage metal complexes were explored. The biscopper complex 36b was found to be the best gas-phase catalyst for both steps in the catalytic cycle (Zavras et al., 2017). Given the difficulty of establishing the nature of the solution-phase catalyst, approaches to translating the gas-phase homogeneous catalysts into a heterogenous system were explored. DFT calculations revealed that the second generation catalyst $\mathbf{3 6 b}$ does not fit into the framework of a ZSM-5 zeolite, which resulted in the development of a new, less bulky catalyst $\mathbf{3 6}$ c based upon the 1,8This article is protected by copyright. All rights reserved. 
naphthyridine ligand (Krstić et al., 2018). This catalytic site was found to fit neatly into the framework a ZSM-5 zeolite.
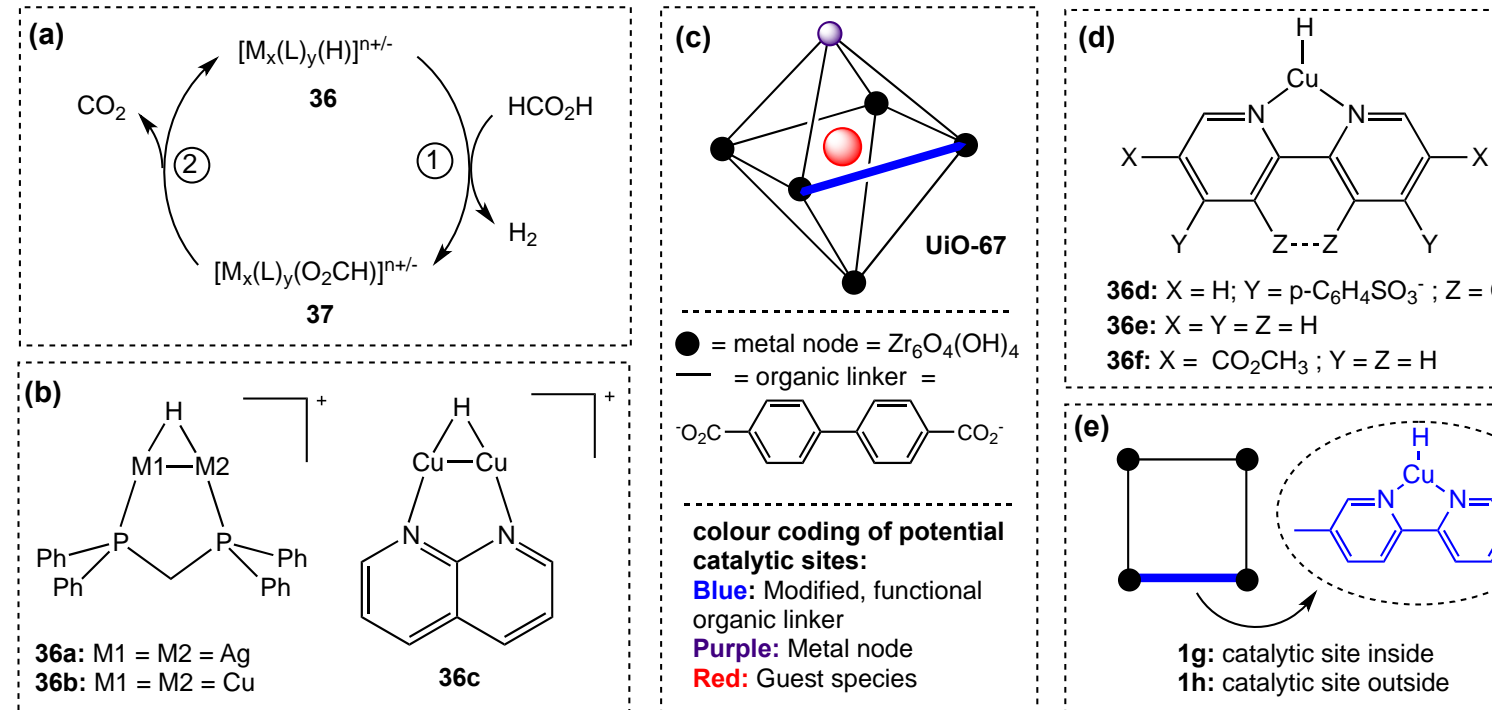

36d: $X=\mathrm{H} ; Y=p-\mathrm{C}_{6} \mathrm{H}_{4} \mathrm{SO}_{3}^{-} ; Z=\mathrm{CH}$ 36e: $X=Y=Z=H$ 36f: $\mathrm{X}=\mathrm{CO}_{2} \mathrm{CH}_{3} ; \mathrm{Y}=\mathrm{Z}=\mathrm{H}$
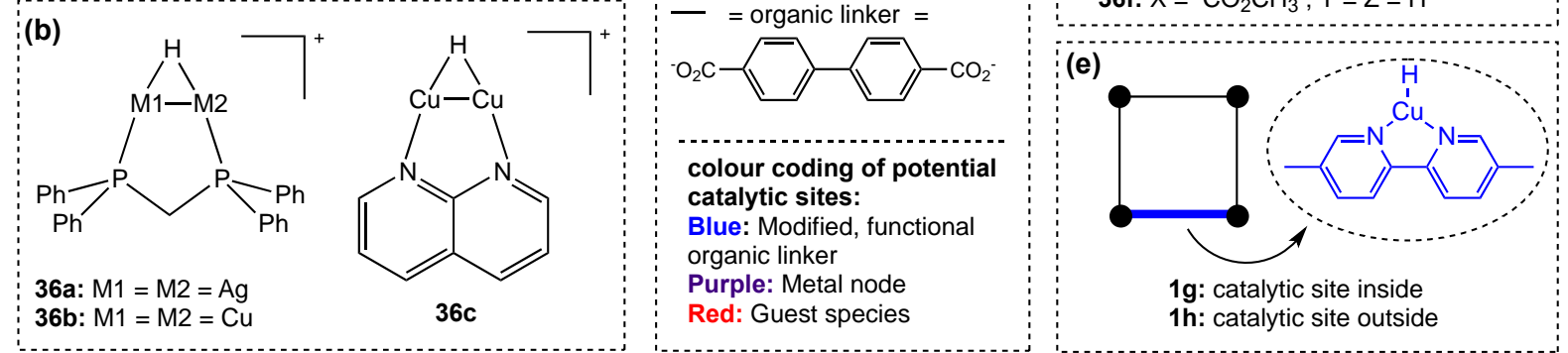

Scheme 25. Design principles for coinage metal hydrides for the selective decarboxylation of formic acid: (a) two-step catalytic cycle. Step (I) is an ion-molecule reaction with formic acid; Step (II) involves liberation of $\mathrm{CO}_{2}$ under CID conditions. (b) $1^{\text {st }}, \mathbf{3 6 a}$ (Zavras et al., 2016), $2^{\text {nd }}, \mathbf{3 6 b}$ (Zavras et al., 2017), and $3^{\text {rd }}, 36 \mathbf{c}$ (Krstić et al., 2018) generation gas-phase binuclear coinage metal hydride catalysts previously reported. (c) examples of potential catalytic sites within the MOF UiO-67; (d) Gasphase models 36d - 36f for mononuclear copper hydride catalysts located at the organic linker (O'Hair et al., 2019); (e) models 36g and 36h for the heterogenization of a gasphase homogenous catalyst located at the organic linker in a MOF (O'Hair et al., 2019).

The experimental challenges of developing these zeolite-based "ship in a bottle" catalysts (Ozin\&Gil, 1989), focused our attention on metal organic frameworks (MOFs) (Hoskins\&Robson 1989; Hoskins\&Robson 1990), which offer three types of potential catalytic sites, as illustrated for the UiO-67 MOF (Scheme 25c) (Huang et al., 2017). Of these, the organic linker, which can be functionalized to introduce a catalytic site, provides an attractive target for our gas-phase model studies (O'Hair et al., 2019). Experiments on the fixed-charge model 36d revealed that the same two-step catalytic cycle (Scheme 25a) operates, while DFT calculations showed that the mechanisms and energetics associated with the two-step catalytic cycle of simple gas-phase catalysts 36d - 36f (Scheme 25d) are very similar to those of the models $\mathbf{3 6 g}$ and $\mathbf{3 6 h}$ of UiOThis article is protected by copyright. All rights reserved. 
67 MOF (Scheme 25e). This suggests that gas-phase models could be used to design new MOF based catalysts.

\section{Development of the new class of ExIn reactions for the synthesis of amides, thioamides and amidines.}

During studies on the gas-phase decarboxylation of metal carboxylates and the subsequent reactions of the resultant organometallic ions it occurred to us that the isoelectronic analogy between $\mathrm{CO}_{2}$ and heterocumulenes opens the door to developing a new class of reactions for organic synthesis that we have termed ExIn (ExtrusionInsertion) (Noor et al., 2017). These reactions involve organometallic intermediates rather than radicals, which tend to be unreactive in the key $\mathrm{C}-\mathrm{C}$ bond forming step unless they are nucleophilic radicals (Weragoda et al., 2018). Due to the high stability of $\mathrm{CO}_{2}$, the overall reaction shown in eq. 38 is exothermic for the preparation of amides (Yang et al., 2020), thioamides (Noor et al., 2017) and amidines (Yang et al., 2019).

$$
\begin{aligned}
& \mathrm{RCO}_{2} \mathrm{H}+\mathrm{R}^{\prime} \mathrm{NCY} \rightarrow \mathrm{RC}(\mathrm{Y}) \mathrm{NR}^{\prime}+\mathrm{CO}_{2} \\
& \left(\mathrm{Y}=\mathrm{O}, \mathrm{S} \text { and } \mathrm{NR}^{\prime}\right)
\end{aligned}
$$

In our studies of ExIn reactions, we showed that gas-phase (Scheme 26A) and solutionphase (Scheme 26B) mechanistic work on ligated palladium complexes can guide the development of one-pot synthetic methods for the palladium mediated ExIn synthesis of amides, thioamides and amidines (Scheme 26C). In the case of thioamides (Noor et al., 2017) and amidines (Yang et al., 2019), the inserted product remains strongly bound to the metal, which is why their synthesis requires stoichiometric amounts of palladium. In contrast, for amides the inserted metal is readily displaced from the metal centre,

This article is protected by copyright. All rights reserved. 
which allowed the development of a rapid microwave protocol that was catalytic in palladium (Yang et al., 2020).
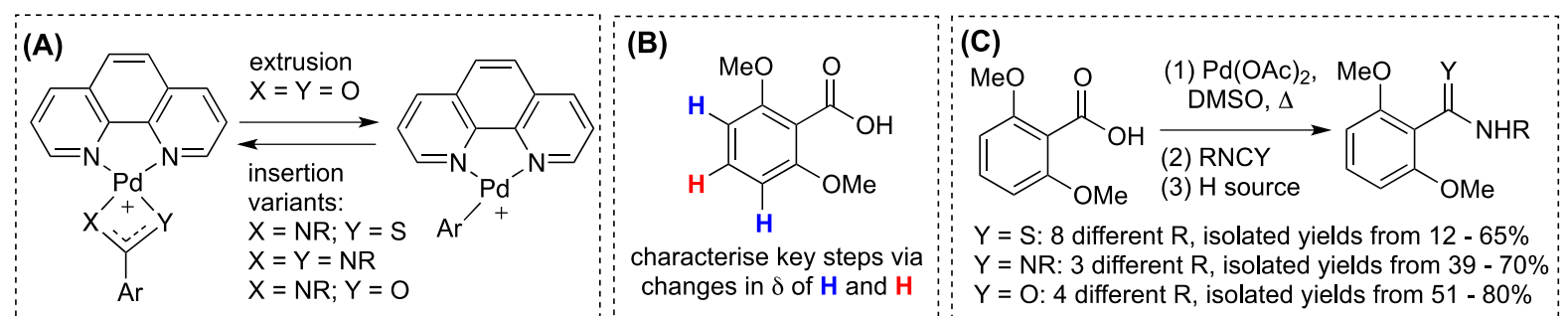

Scheme 26: Example of a mechanism-based approach guiding the development of new methods in organic synthesis: gas-phase (A) and solution-phase NMR studies (B), and one-pot synthesis of thioamides, amidines and amides from carboxylic acids (C).

\section{Conclusions.}

A diverse range of reactivity is observed in the gas-phase reactions of metal species (bare metal cations, clusters, inorganic and organometallic complexes) with carboxylic acids and their derivatives. Reactivity can occur at the functional group (e.g. dehydration and decarboxylation) or remote from the functional group via $\mathrm{C}-\mathrm{H}$ and $\mathrm{C}$ $\mathrm{C}$ bond activation. Apart from shedding light on the mechanistic aspects of known reactions, the value of these gas-phase studies is that: new examples of reactions have been uncovered that have not been tried in solution (e.g. Ni catalyzed protodecarboxylation and decarboxylative $\mathrm{C}-\mathrm{C}$ bond coupling); new modes of reactivity have been discovered that do not appear to have a solution-phase precedence (e.g. dehydro decarboxylative coupling of two acetate ligands, eq. 7). Mass spectrometry has been widely used by solution phase chemists interested in catalysis. Apart from the use of MS to analyze the final products of a catalytic reaction, ESI/MS is being exploited to probe solution phase intermediates associated with metal catalysts (Chen, 2003; Santos, 2008; Santos, 2010A\&B; Schröder, 2012; Vikse\& McIndoe, 2015; Yunker et al., 2014; Iacobucci et al., 2016), including monitoring the temporal evolution of intermediates to extract kinetic data (Yunker et al., 2014; Stoddard et al., This article is protected by copyright. All rights reserved. 
2014; Vikse et al., 2014). An exciting emerging area is the combination of gas- and condensed-phase studies to discover new metal catalysts and reactions that can then be translated into the homogenous or heterogenous catalytic transformation of substrates.

\author{
Abbreviations. \\ Collision induced dissociation (CID) \\ Density functional theory (DFT) \\ Electrospray Ionization (ESI) \\ Ion-molecule reactions (IMR) \\ Multistage mass spectrometry $\left(\mathrm{MS}^{\mathrm{n}}\right)$ \\ Acknowledgements.
}

I thank the ARC for their generous financial support of my metal mediated studies over the past decade, most recently via grants DP110103844, DP150101388 and DP180101187, and through the ARC CoE program. I acknowledge all the students, post-doctoral fellows and collaborators involved in helping develop a mechanistic understanding of metal-mediated reactions of carboxylic acids.

\title{
12. References.
}

Ackermann L. 2011. Carboxylate-Assisted Transition-Metal-Catalyzed C-H Bond Functionalizations: Mechanism and Scope. Chem. Rev. 111:1315-1345.

Aggarwal VKS, K.. 2006. Patai Series: The Chemistry of Functional Groups. The Chemistry of Organozinc Compounds: John Wiley \& Sons Ltd.

Åkermark B, Ljungqvist A. 1979. The thermal formation of bialkyls from alkylmetals: III. Thermolysis of neophyl complexes of the first row transition metals. J. Organomet. Chem. 182:47-58.

Al Sharif H, Vikse KL, Khairallah GN, O'Hair RAJ. 2013. Catalytic Decarboxylative Coupling of Allyl Acetate: Role of the Metal Centers in the Organometallic Cluster Cations $\left[\mathrm{CH}_{3} \mathrm{Cu}_{2}\right]^{+},\left[\mathrm{CH}_{3} \mathrm{AgCu}\right]^{+}$, and $\left[\mathrm{CH}_{3} \mathrm{Ag}_{2}\right]^{+}$. Organometallics 32:5416-5427.

This article is protected by copyright. All rights reserved. 
Albrecht M. 2010. Cyclometalation Using d-Block Transition Metals: Fundamental Aspects and Recent Trends. Chem. Rev. 110:576-623.

Allen AD, Tidwell TT. 2013. Ketenes and Other Cumulenes as Reactive Intermediates. Chem. Rev. (Washington, DC, U. S.) 113:7287-7342.

Allen AD, Tidwell TT. 2016. Recent advances in ketene chemistry. ARKIVOC 415490.

Anastas P, Warner J. 1998. Green Chemistry: Theory and Practice: Oxford Univ Press.

Armentrout PB. 1999. Gas-phase organometallic chemistry. Top. Organomet. Chem. 4:1-45.

Armentrout PB. 2001. Reactions and thermochemistry of small transition metal cluster ions. Annu. Rev. Phys. Chem. 52:423-461.

Armentrout PB. 2010. Reactivity and Thermochemistry of Transition Metal Cluster Cations. in Nanoclusters: A Bridge across Disciplines. Jena P, Castleman A. Eds, Elsevier, Chapter 6 pp 269-297.

Armentrout PB. 2014. Gas-phase perspective on the thermodynamics and kinetics of heterogeneous catalysis. Catal. Sci. Technol. 4:2741-2755.

Armentrout PB, Beauchamp JL. 1989. The chemistry of atomic transition-metal ions: insight into fundamental aspects of organometallic chemistry. Acc. Chem. Res. 22:315321.

Astruc D. 2007. Organometallic Chemistry and Catalysis: Springer.

Attygalle AB, Axe FU, Weisbecker CS. 2011. Mild route to generate gaseous metal anions. Rapid Commun. Mass Spectrom. 25:681-688.

Barteau MA. 1996. Organic Reactions at Well-Defined Oxide Surfaces. Chem. Rev. 96:1413-1430.

Baudoin O. 2007. New approaches for decarboxylative biaryl coupling. Angew. Chem., Int. Ed. 46:1373-1375.

Behrouzian B, Buist PH. 2003. Mechanism of fatty acid desaturation: a bioorganic perspective. Prostaglandins, Leukotrienes Essent. Fatty Acids 68:107-112.

Bergbreiter DE, Lynch TJ. 1981. Thermolysis of butylsilver(I) ate complexes. J. Org. Chem. 46:727-733.

Biafora A, Goossen LJ. 2017. New Reaction Mode in Carboxylate-Directed C-H Functionalizations: Carboxylates as Deciduous Directing Groups. Synlett 28:18851890.

Bigi MA, Reed SA, White MC. 2012. Directed Metal (Oxo) Aliphatic C-H Hydroxylations: Overriding Substrate Bias. J. Am. Chem. Soc. 134:972 1-9726.

This article is protected by copyright. All rights reserved. 
Blaziak K, Tzeli D, Xantheas SS, Uggerud E. 2018. The activation of carbon dioxide by first row transition metals (Sc-Zn). Phys. Chem. Chem. Phys. 20:25495-25505.

Breslow R. 1972. Centenary Lecture. Biomimetic chemistry. Chem. Soc. Rev. 1:553580 .

Breslow R. 1980. Biomimetic control of chemical selectivity. Acc. Chem. Res. 13:170177.

Brown RFC. 1980. Pyrolytic Methods in Organic Chemistry: Application of Flow and Flash Vacuum Pyrolytic Techniques: Academic Press.

Butschke B, Schwarz H. 2010. Mechanistic Study on the Gas-Phase Generation of "Rollover"-Cyclometalated [M(bipy - H) $]^{+}(\mathrm{M}=\mathrm{Ni}$, Pd, Pt). Organometallics 29:60026011.

Butschke B, Schwarz H. 2012. "Rollover" cyclometalation - early history, recent developments, mechanistic insights and application aspects. Chem. Sci. 3:308-326.

Butson JM, Curtis S, Mayer PM. 2016. Electron transfer and multi-atom abstraction reactions between atomic metal anions and $\mathrm{NO}, \mathrm{NO}_{2}$ and $\mathrm{SO}_{2}$. Chem. Phys. Lett. 651:203-208.

Campeau L-C, Hazari N. 2019. Cross-Coupling and Related Reactions: Connecting Past Success to the Development of New Reactions for the Future. Organometallics 38:3-35.

Camus A, Marsich N, Manotti Lanfredi AM, Ugozzoli F. 1990. Insertion reaction of carbon disulfide into copper-carbon bonds of aromatic organocopper(I) compounds, in the presence of 2,2' -bipyridine and 1,10-phenanthroline. X-ray diffraction structures of the $\left[\left(\mathrm{CuS}_{3} \mathrm{C}\right.\right.$-o-tolyl $)$ phen $],\left[\left(\mathrm{CuS}_{3} \mathrm{C} \text {-o-tolyl }\right)_{2}\right.$ phen $]$ and $\left[\mathrm{Cu}_{2}\left(\mathrm{~S}_{3} \mathrm{C}\right.\right.$-o-tolyl $)\left(\mathrm{S}_{2} \mathrm{C}\right.$-otolyl)bipy] complexes. Inorg. Chim. Acta 175:193-202.

Camus A, Marsich N, Nardin G. 1980. Insertion reactions of carbon disulfide into carbon-copper bonds of aromatic organocopper(I) compounds and of their complexes with triphenylphosphine and bis(diphenylphosphino) ethane. J. Organomet. Chem. 188:389-399.

Canale V, Zavras A, Khairallah GN, d'Alessandro N, O'Hair RAJ. 2015. Gas-Phase Reactions of the Rhenium Oxide Anions, $\left[\mathrm{ReO}_{\mathrm{x}}\right]^{-}(\mathrm{x}=2-4)$ with the Neutral Organic Substrates Methane, Ethene, Methanol and Acetic Acid. Eur. J. Mass Spectrom. 21: $557-568$.

Carrow BP, Sampson J, Wang L. 2020. Base-Assisted C-H Bond Cleavage in CrossCoupling: Recent Insights into Mechanism, Speciation, and Cooperativity. Isr. J. Chem. 60: $230-258$.

Chalupsky J, Rokob TA, Kurashige Y, Yanai T, Solomon EI, Rulisek L, Srnec M. 2014. Reactivity of the binuclear non-heme iron active site of $\Delta 9$ desaturase studied by largescale multireference ab initio calculations. J. Am. Chem. Soc. 136:15977-15991.

This article is protected by copyright. All rights reserved. 
Chen LZ, Miller JM. 1991. Ion-molecule reactions of transition-metal ions with nitriles in the gas-phase: competitive formation of both "end-on" and "side-on" coordination. Can. J. Chem. 69:2002-2007.

Chen P. 2003. Electrospray ionization tandem mass spectrometry in high-throughput screening of homogeneous catalysts. Angew. Chem., Int. Ed. 42:2832-2847.

Cheng G-J, Zhong X-M, Wu Y-D, Zhang X. 2019. Mechanistic understanding of catalysis by combining mass spectrometry and computation. Chem. Commun. 55:12749-12764.

Clark JM, Nimlos MR, Robichaud DJ. 2014. Comparison of Unimolecular Decomposition Pathways for Carboxylic Acids of Relevance to Biofuels. J. Phys. Chem. A 118:260-274.

Colton R, D'Agostino A, Traeger JC. 1995. Electrospray mass spectrometry applied to inorganic and organometallic chemistry. Mass Spectrom. Rev. 14:79-106.

Corma A, Iborra S, Velty A. 2007. Chemical Routes for the Transformation of Biomass into Chemicals. Chem. Rev. 107:2411-2502.

Cornella J, Larrosa I. 2012. Decarboxylative carbon-carbon bond-forming transformations of (hetero)aromatic carboxylic acids. Synthesis 44:653-676.

Cornella J, Righi M, Larrosa I. 2011. Carboxylic Acids as Traceless Directing Groups for Formal meta-Selective Direct Arylation. Angew. Chem., Int. Ed. 50:9429-9432.

Cornella J, Sanchez C, Banawa D, Larrosa I. 2009. Silver-catalyzed protodecarboxylation of ortho-substituted benzoic acids. Chem. Commun. 7176-7178.

Cornella J, Rosillo-Lopez M, Larrosa I. 2011. A Novel Mode of Reactivity for Gold(I): The Decarboxylative Activation of (Hetero)Aromatic Carboxylic Acids. Adv. Synth. Catal. 353:1359-1366.

Curtis S, DiMuzio J, Mungham A, Roy J, Hassan D, Renaud J, Mayer PM. 2011. Reactions of Atomic Metal Anions in the Gas phase: Competition between Electron Transfer, Proton Abstraction and Bond Activation. J. Phys. Chem. A 115:14006-14012.

Curtis S, Renaud J, Holmes JL, Mayer PM. 2010. Old Acid, New Chemistry. Negative Metal Anions Generated from Alkali Metal Oxalates and Others. J. Am. Soc. Mass Spectrom. 21:1944-1946.

Czekay G, Drewello T, Eller K, Zummack W, Schwarz H. 1989. Origin of the distinctly different gas-phase chemistry of linear and $\alpha$-branched aliphatic nitriles with bare iron(I) ions. Evidence for oxidative addition of the carbon-cyano bond to iron(+), new mechanisms for the reductive eliminations of alkanes, and a demonstration of consecutive carbon-hydrogen/carbon-carbon bond activations of different sites of flexible molecules. Organometallics 8:2439-2446.

Czekay G, Drewello T, Schwarz H. 1989. The oxidative addition of the carbonhydrogen bond is not the rate-determining step in the remote functionalization of nitriles by bare iron(I) ions. J. Am. Chem. Soc. 111:4561-4563.

This article is protected by copyright. All rights reserved. 
Daley RA, Topczewski JJ. 2020. Aryl-Decarboxylation Reactions Catalyzed by Palladium: Scope and Mechanism. Synthesis 52:365-377.

Davies DL, Macgregor SA, McMullin CL. 2017. Computational Studies of Carboxylate-Assisted C-H Activation and Functionalization at Group 8-10 Transition Metal Centers. Chem. Rev. 117:8649-8709.

Dawes GJS, Scott EL, Le Nôtre J, Sanders JPM, Bitter JH. 2015. Deoxygenation of biobased molecules by decarboxylation and decarbonylation - a review on the role of heterogeneous, homogeneous and bio-catalysis. Green Chem. 17:3231-3250.

Deacon GB. 1970. Syntheses of organometallic compounds by thermal decarboxylation. Organometal. Chem. Rev., Sect. A 5:355-372.

Deacon GB, Faulks SJ, Pain GN. 1986. The synthesis of organometallics by decarboxylation reactions. Adv. Organomet. Chem. 25:237-276.

Dermenci A, Dong GB. 2013. Decarbonylative C-C bond forming reactions mediated by transition metals. Sci. China: Chem. 56:685-701.

Dickstein JS, Curto JM, Gutierrez O, Mulrooney CA, Kozlowski MC. 2013. Mild aromatic palladium-catalyzed protodecarboxylation: kinetic assessment of the decarboxylative palladation and the protodepalladation steps. J. Org. Chem. 78:47444761.

Dickstein JS, Mulrooney CA, O'Brien EM, Morgan BJ, Kozlowski MC. 2007. Development of a Catalytic Aromatic Decarboxylation Reaction. Org. Lett. 9:2441 2444.

Donald WA, Khairallah GN, O'Hair RAJ. 2013. The Effective Temperature of Ions Stored in a Linear Quadrupole Ion Trap Mass Spectrometer. J. Am. Soc. Mass Spectrom. 24:811-815.

Dossmann H, Afonso C, Lesage D, Tabet J-C, Uggerud E. 2012. Formation and Characterization of Gaseous Adducts of Carbon Dioxide to Magnesium, $\left(\mathrm{CO}_{2}\right) \mathrm{MgX}^{-}$ $(\mathrm{X}=\mathrm{OH}, \mathrm{Cl}, \mathrm{Br})$. Angew. Chem., Int. Ed. 51:6938-6941.

Duchackova L, Schröder D, Roithová J. 2011. Effect of the Carboxylate Shift on the Reactivity of Zinc Complexes in the Gas Phase. Inorg. Chem. 50:3153-3158.

Dupuy S, Crawford L, Buehl M, Nolan SP. 2015. The Gold(I)-Catalysed Protodecarboxylation Mechanism. Chem. Eur. J. 21:3399-3408.

Dupuy S, Nolan SP. 2013. Gold(I)-Catalyzed Protodecarboxylation of (Hetero)Aromatic Carboxylic Acids. Chem. Eur. J. 19:14034-14038.

Dzik WI, Lange PP, Goossen LJ. 2012. Carboxylates as sources of carbon nucleophiles and electrophiles: comparison of decarboxylative and decarbonylative pathways. Chem. Sci. 3:2671-2678.

Ebrahimi M, Fernando Rios J, Leung KT. 2009. Dissociative adsorption and thermal evolution of acetic acid on $\operatorname{Si}(100) 2 \times 1$. Surface-mediated formation of ketene and

This article is protected by copyright. All rights reserved. 
acetaldehyde from unidentate and bidentate acetate adsorbates. J. Phys. Chem. C 113:281-289.

Eller K. 1993. Reactions of monosubstituted alkanes with bare metal ions. An effort toward a more unified picture for the gas-phase chemistry of R-X molecules. Coord. Chem. Rev. 126:93-147.

Eller K, Schwarz H. 1991. Organometallic chemistry in the gas phase. Chem. Rev. 91:1121-1177.

Eller K, Zummack W, Schwarz H. 1990. Detection and characterization of competitive processes giving rise to isomeric products in the reactions of iron $(1+)$, cobalt $(1+)$ and nickel(1+) with n-butyl cyanide. Int. J. Mass Spectrom. Ion Proc. 100:803-819.

Eller K, Zummack W, Schwarz H, Roth LM, Freiser BS. 1991. The gas-phase chemistry of iron cation with n-pentanenitrile: a seemingly simple system? J. Am. Chem. Soc. 113:833-839.

Fenn JB, Mann M, Meng CK, Wong SF, Whitehouse CM. 1989. Electrospray ionization for mass spectrometry of large biomolecules. Science 246:64-71.

Fenton DM. 1970. Olefins from carboxylic acids, esters, anhydrides or acid halides. Union Oil Co. Patent US3530198A.

Fernandez I, Cossio FP, Sierra MA. 2009. Dyotropic Reactions: Mechanisms and Synthetic Applications. Chem. Rev. 109:6687-6711.

Fisher KJ. 2001. Gas-phase coordination chemistry of transition metal ions. Prog. Inorg. Chem. 50:343-432.

Foglia TA, Barr PA. 1976. Decarbonylation dehydration of fatty acids to alkenes in the presence of transition metal complexes. J. Am. Oil Chem. Soc. 53:737-741.

Fox BG, Lyle KS, Rogge CE. 2004. Reactions of the Diiron Enzyme Stearoyl-Acyl Carrier Protein Desaturase. Acc. Chem. Res. 37:421-429.

Gibson JK. 1999. Actinide Gas-Phase Chemistry: Reactions of $\mathrm{An}^{+}$and $\mathrm{AnO}^{+}[\mathrm{An}=$ Th, U, Np, Pu, Am] with Nitriles and Butylamine. Inorg. Chem. 38:165-173.

Glaser C. 1869. Beiträge zur Kenntniss des Acetenylbenzols. Ber. Deutsch. Chem. Gesell. 2:422-424.

Godula K, Sames D. 2006. C-H Bond Functionalization in Complex Organic Synthesis. Science 312:67-72.

Goossen LJ, Editor. 2013. Inventing Reactions. Springer GmbH.

Goossen LJ, Collet F, Goossen K. 2010. Decarboxylative coupling reactions. Isr. J. Chem. 50:617-629.

Goossen LJ, Goossen K. 2013. Decarboxylative coupling reactions. Top. Organomet. Chem. 44:121-142.

This article is protected by copyright. All rights reserved. 
Goossen LJ, Goossen K, Rodriguez N, Blanchot M, Linder C, Zimmermann B. 2008. New catalytic transformations of carboxylic acids. Pure Appl. Chem. 80:1725-1733.

Goossen LJ, Linder C, Rodriguez N, Lange PP, Fromm A. 2009. Silver-catalyzed protodecarboxylation of carboxylic acids. Chem. Commun. 7173-7175.

Goossen LJ, Manjolinho F, Khan BA, Rodriguez N. 2009. Microwave-Assisted CuCatalyzed Protodecarboxylation of Aromatic Carboxylic Acids. J. Org. Chem. $74: 2620-2623$.

Goossen LJ, Rodriguez N, Goossen K. 2008. Carboxylic acids as substrates in homogeneous catalysis. Angew. Chem., Int. Ed. 47:3100-3120.

Goossen LJ, Rodriguez N, Linder C, Lange PP, Fromm A. 2010. Comparative Study of Copper- and Silver-Catalyzed Protodecarboxylations of Carboxylic Acids. ChemCatChem 2:430-442.

Goossen LJ, Thiel WR, Rodriguez N, Linder C, Melzer B. 2007. Copper-catalyzed protodecarboxylation of aromatic carboxylic acids. Adv. Synth. Catal. 349:2241-2246.

Goossen LJ, Zimmermann B, Knauber T. 2010. Pd-catalyzed decarboxylative Heck vinylation of 2-nitrobenzoates in the presence of $\mathrm{CuF}_{2}$. Beil. J. Org. Chem. 6:No. 43, doi:10.3762/bjoc.6.43.

Gosselink RW, Hollak SAW, Chang S-W, van Haveren J, de Jong KP, Bitter JH, van Es DS. 2013. Reaction Pathways for the Deoxygenation of Vegetable Oils and Related Model Compounds. ChemSusChem 6:1576-1594.

Grainger R, Cornella J, Blakemore DC, Larrosa I, Campanera JM. 2014. The orthoSubstituent Effect on the Ag-Catalysed Decarboxylation of Benzoic Acids. Chem. Eur. J. 20:16680-16687.

Grainger R, Nikmal A, Cornella J, Larrosa I. 2012. Selective deuteration of (hetero)aromatic compounds via deutero-decarboxylation of carboxylic acids. Org. Biomol. Chem. 10:3172-3174.

Grasemann M, Laurenczy G. 2012. Formic acid as a hydrogen source - recent developments and future trends. Ener. Environ. Sci. 5:8171-8181.

Gray A, Tsybizova A, Roithová J. 2015. Carboxylate-assisted C-H activation of phenylpyridines with copper, palladium and ruthenium: A mass spectrometry and DFT study. Chem. Sci. 6:5544-5553.

Gronert S. 1998. Estimation of effective ion temperatures in a quadrupole ion trap. J. Am. Soc. Mass Spectrom. 9:845-848.

Groves JT, Nemo TE, Myers RS. 1979. Hydroxylation and epoxidation catalyzed by iron-porphine complexes. Oxygen transfer from iodosylbenzene. J. Am. Chem. Soc. 101:1032-1033.

Guo L, Rueping M. 2018A. Transition-Metal-Catalyzed Decarbonylative Coupling Reactions: Concepts, Classifications, and Applications. Chem. Eur. J. 24:7794-7809.

This article is protected by copyright. All rights reserved. 
Guo L, Rueping M. 2018B. Decarbonylative Cross-Couplings: Nickel Catalyzed Functional Group Interconversion Strategies for the Construction of Complex Organic Molecules. Acc. Chem. Res. 51:1185-1195.

Gutierrez O, Tantillo DJ. 2012. Analogies between Synthetic and Biosynthetic Reactions in Which [1,2]-Alkyl Shifts Are Combined with Other Events: Dyotropic, Schmidt, and Carbocation Rearrangements. J. Org. Chem. 77:8845-8850.

Hashimoto H, Nakano T. 1966. Thermal Decomposition of Copper and Silver Aryls in Aprotic Media1. J. Org. Chem. 31:891-894.

Henderson W, McIndoe JS. 2004. Electrospray mass spectrometry. Comprehensive Coordination Chemistry II, 2: 387-391.

Helwani Z, Othman MR, Aziz N, Fernando WJN, Kim J. 2009. Technologies for production of biodiesel focusing on green catalytic techniques: A review. Fuel Proc. Tech. 90:1502-1514.

Holthausen MC, Hornung G, Schröder D, Sen S, Koch W, Schwarz H. 1997. Synergy of Theory and Experiment in the Remote Functionalization of Aliphatic Nitriles by "Bare" Fe(I) and Co(I) Cations in the Gas Phase. Organometallics 16:3135-3147.

Hornung G, Schröder D, Schwarz H. 1995. Diastereoselective Gas-Phase CarbonCarbon Bond Activation Mediated by "Bare" $\mathrm{Co}^{+}$Cations. J. Am. Chem. Soc. 117:8192-8196.

Hoskins BF, Robson R. 1989. Infinite polymeric frameworks consisting of three dimensionally linked rod-like segments. J. Am. Chem. Soc. 111: 5962-5964.

Hoskins BF, Robson R. 1990. Design and construction of a new class of scaffoldinglike materials comprising infinite polymeric frameworks of 3D-linked molecular rods. A reappraisal of the zinc cyanide and cadmium cyanide structures and the synthesis and structure of the diamond-related frameworks $\left[\mathrm{N}\left(\mathrm{CH}_{3}\right)_{4}\right]\left[\mathrm{CuIZnII}(\mathrm{CN})_{4}\right]$ and $\mathrm{CuI}[4,4$ ',4",4"'-tetracyanotetraphenylmethane $] \mathrm{BF}_{4} \cdot \mathrm{xC}_{6} \mathrm{H}_{5} \mathrm{NO}_{2}$. J. Am. Chem. Soc. 112: $1546-1554$.

House HO, DuBose JC. 1975. Reduction as a side reaction arising from the thermal decomposition of lithium organocuprates to form copper hydride derivatives. J. Org. Chem. 40:788-790.

Huang YB, Liang J, Wang XS, Cao R. 2017. Multifunctional metal-organic framework catalysts: synergistic catalysis and tandem reactions. Chem. Soc. Rev. 46: 126-157.

Hummel JR, Boerth JA, Ellman JA. 2017. Transition-Metal-Catalyzed C-H Bond Addition to Carbonyls, Imines, and Related Polarized $\pi$ Bonds. Chem. Rev. 117:91639227.

Iacobucci C, Reale S, De Angelis F. 2016. Elusive Reaction Intermediates in Solution Explored by ESI-MS: Reverse Periscope for Mechanistic Investigations. Angew. Chem., Int. Ed. 55:2980-2993.

This article is protected by copyright. All rights reserved. 
Ignatchenko AV. 2011. Density Functional Theory Study of Carboxylic Acids Adsorption and Enolization on Monoclinic Zirconia Surfaces. J. Phys. Chem. C 115:16012-16018.

James PF, O'Hair RAJ. 2004. Dimethyl Cuprate Undergoes C-C Bond Coupling with Methyliodide in the Gas Phase but Dimethyl Argenate Does Not. Org. Lett. 6:27612764.

Jasikova L, Roithová J. 2018. Infrared Multiphoton Dissociation Spectroscopy with Free-Electron Lasers: On the Road from Small Molecules to Biomolecules. Chem. Eur. J. 24:3374-3390.

Jestila JS, Denton JK, Perez EH, Khuu T, Apra E, Xantheas SS, Johnson MA, Uggerud E. 2020. Characterization of the alkali metal oxalates $\left(\mathrm{MC}_{2} \mathrm{O}_{4}{ }^{-}\right)$and their formation by $\mathrm{CO}_{2}$ reduction via the alkali metal carbonites $\left(\mathrm{MCO}_{2}^{-}\right)$. Phys. Chem. Chem. Phys. 22:7460-7473.

Jestila JS, Uggerud E. 2018. Unimolecular dissociation of anions derived from succinic acid $\left(\mathrm{H}_{2} \mathrm{Su}\right)$ in the gas phase form $\mathrm{HSu}^{-}$and $\mathrm{ClMgSu}^{-}$. Relationship to $\mathrm{CO}_{2}$ fixation. Eur. J. Mass Spectrom. 24:33-42.

John A, Hillmyer MA, Tolman WB. 2017. Anhydride-Additive-Free Nickel-Catalyzed Deoxygenation of Carboxylic Acids to Olefins. Organometallics 36:506-509.

John A, Miranda MO, Ding K, Dereli B, Ortuño MA, LaPointe AM, Coates GW, Cramer CJ, Tolman WB. 2016. Nickel Catalysts for the Dehydrative Decarbonylation of Carboxylic Acids to Alkenes. Organometallics 35:2391-2400.

Katritzky AR, Cozens AJ, Ossana A, Rubio O, Dabbas N. 1985. Some novel reactions of pyridinium-2-carboxylate betaines. J. Chem. Soc. Perkin Trans. 1 2167-2172.

Keith JA, Behenna DC, Sherden N, Mohr JT, Ma S, Marinescu SC, Nielsen RJ, Oxgaard J,

Khairallah GN, Waters T, O'Hair RAJ. 2009. C-C Bond Coupling Between the Organometallic Cations $\mathrm{CH}_{3} \mathrm{Ag}_{2}{ }^{+}, \mathrm{CH}_{3} \mathrm{Cu}_{2}{ }^{+}$and $\mathrm{CH}_{3} \mathrm{AgCu}^{+}$and Allyliodide. Dalton Trans. 2832-2836

Khairallah GN, Waters T, Wedd AG, O'Hair RAJ. 2018. C-F Bond Activation of Trifluoroethanol and Trifluoroacetic Acid Catalysed by the Dimolybdate Anion, $\left[\mathrm{Mo}_{2} \mathrm{O}_{6}(\mathrm{~F})\right]^{-}$. Eur. J. Mass Spectrom. 24: 43-48.

Khairallah GN, Williams CM, Chow S, O’Hair RAJ. 2013. sp-sp ${ }^{3}$ Coupling Reactions of Alkynylsilver Cations, $\mathrm{RC} \equiv \mathrm{CAg}_{2}{ }^{+}(\mathrm{R}=\mathrm{Me}$ and $\mathrm{Ph})$ with Allyliodide. Dalton Trans. 42: 9462-9467.

Knothe G. 2010. Biodiesel and renewable diesel: A comparison. Prog. Energy Combust. Sci. 36:364-373.

Kolarovic A, Faberova Z. 2009. Catalytic Decarboxylation of 2-Alkynoic Acids. J. Org. Chem. 74:7199-7202.

This article is protected by copyright. All rights reserved. 
Krause N. 2002. Modern Organocopper Chemistry: Wiley-VCH Verlag GmbH.

Krstić M, Jin Q, Khairallah GN, O'Hair RAJ, Bonačić-Koutecký V. 2018. How to Translate the $\left[\mathrm{LCu}_{2}(\mathrm{H})\right]^{+}$- Catalysed Selective Decomposition of Formic Acid into $\mathrm{H}_{2}$ and $\mathrm{CO}_{2}$ from the Gas Phase into a Zeolite. ChemCatChem 10:1173-1177.

Kulik TV. 2012. Use of TPD-MS and Linear Free Energy Relationships for Assessing the Reactivity of Aliphatic Carboxylic Acids on a Silica Surface. J. Phys. Chem. C 116:570-580.

Lanfredi AMM, Tiripicchio A, Camus A, Marsich N. 1983. A novel reaction of $\mathrm{CS}_{2}$ with organocopper(I) complexes. Synthesis and structure of \{tetra[ $[\mu-$ bis(diphenylphosphino)methane]di- $\mu$ 4-trithio-carbonato $\}$ tetracopper(I)-toluene. J. Chem. Soc. Chem. Comm. 1126-1128.

Lang SB, O’Nele KM, Tunge JA. 2014. Decarboxylative Allylation of Amino Alkanoic Acids and Esters via Dual Catalysis. J. Am. Chem. Soc. 136:13606-13609.

Lang SM, Bernhardt TM. 2012. Gas phase metal cluster model systems for heterogeneous catalysis. Phys. Chem. Chem. Phys. 14:9255-9269.

Lang SM, Popolan DM, Bernhardt TM. 2007. Chemical reactivity and catalytic properties of size-selected gas-phase metal clusters. Chem. Phys. Solid Surf. 12:53-90.

Lebrasseur N, Larrosa I. 2008. Room Temperature and Phosphine Free Palladium Catalyzed Direct C-2 Arylation of Indoles. Journal of the American Chemical Society 130:2926-2927.

Lebrilla CB, Schulze C, Schwarz H. 1987. Reaction of nitriles and iron(1+) in the gas phase. A case of remote functionalization. J. Am. Chem. Soc. 109:98-100.

Lebrilla CB, Drewello T, Schwarz H. 1987. The reaction of linear nitriles with transition metal ions $\mathrm{M}^{+}(\mathrm{M}=$ iron, cobalt and nickel $)$ in the gas phase. Does the backbonding ability of the metal ions govern the geometry of the RCN/M ${ }^{+}$complexes and what is the effect on the oxidative addition of internal CH bonds? Int. J. Mass Spectrom. Ion Proc. 79:287-294.

Lebrilla CB, Drewello T, Schwarz H. 1987. Only the copper(I) ion coordinated to the $\pi$-system of the nitrile group activates upon collision carbon-hydrogen and carboncarbon bonds of nitriles. Organometallics 6:2450-2451.

Lebrilla CB, Drewello T, Schwarz H. 1987. Deceptive similarities in the reactions of iron(I) and cobalt(I) with linear nitriles in the gas phase. J. Am. Chem. Soc. 109:56395644.

Leeming MG, Khairallah GN, Osburn S, Vikse K, O'Hair RAJ. 2014. Cobalt-Mediated Decarboxylative Homocoupling of Alkynyl Carboxylic Acids. Aust. J. Chem. 67:701 710.

Leibfarth FA, Hawker CJ. 2013. The emerging utility of ketenes in polymer chemistry. J. Polym. Sci. A 51:3769-3782.

This article is protected by copyright. All rights reserved. 
Lesslie M, Yang Y, Canty AJ, Piacentino E, Berthias F, Maitre P, Ryzhov V, O'Hair RAJ. 2018. Ligand-induced decarbonylation in diphosphine-ligated palladium acetates $\left[\mathrm{CH}_{3} \mathrm{CO}_{2} \mathrm{Pd}\left(\left(\mathrm{PR}_{2}\right)_{2} \mathrm{CH}_{2}\right)\right]^{+}(\mathrm{R}=\mathrm{Me}$ and $\mathrm{Ph})$. Chem. Commun. 54:346-349.

Li H, Miao T, Wang M, Li P, Wang L. 2016. Recent Advances in Exploring Diverse Decarbonylation, Decarboxylation and Desulfitation Coupling Reactions for Organic Transformations. Synlett 27:1635-1648.

Li J, Khairallah GN, O'Hair RAJ. 2015. Dimethylcuprate-Mediated Transformation of Acetate to Dithioacetate. Organometallics 34:488-493.

Li Z, Jiang Y-Y, Yeagley AA, Bour JP, Liu L, Chruma JJ, Fu Y. 2012. Mechanism of the Pd-catalyzed Decarboxylative Allylation of $\alpha$-Imino Esters: Decarboxylation via Free Carboxylate Ion. Chem. Eur. J. 18:14527-14538.

Libby MC, Watson PC, Barteau MA. 1994. Synthesis of Ketenes with Oxide Catalysts. Ind. Eng. Chem. Res. 33:2904-2912.

Loos J, Schröder D, Zummack W, Schwarz H. 2002. Regio- and diastereoselective C$\mathrm{H}$ bond activation of valeramide and 3-methylvaleramide by bare $\mathrm{Fe}^{+}$ions. Int. J. Mass Spectrom. 217:169-177.

Lu P, Sanchez C, Cornella J, Larrosa I. 2009. Silver-Catalyzed Protodecarboxylation of Heteroaromatic Carboxylic Acids. Org. Lett. 11:5710-5713.

Lu J, Behtash S, Heyden A. 2012. Theoretical Investigation of the Reaction Mechanism of the Decarboxylation and Decarbonylation of Propanoic Acid on Pd(111) Model Surfaces. J. Phys. Chem. C 116:14328-14341.

Lyons TW, Sanford MS. 2010. Palladium-Catalyzed Ligand-Directed C-H Functionalization Reactions. Chem. Rev. 110:1147-1169.

MacAleese L, Maitre P. 2007. Infrared spectroscopy of organometallic ions in the gas phase: from model to real world complexes. Mass Spectrom. Rev. 26:583-605.

Martinez R, Huff MC, Barteau MA. 2004. Ketonization of acetic acid on titaniafunctionalized silica monoliths. J. Catal. 222:404-409.

Matsubara S, Yokota Y, Oshima K. 2004. Palladium-catalyzed decarboxylation and decarbonylation under hydrothermal conditions: decarboxylative deuteration. Org. Lett. 6:2071-2073.

McKay AI, Altalhi WAO, McInnes LE, Czyz ML, Canty AJ, Donnelly PS, O'Hair RAJ. 2020. Identification of the Side Products That Diminish the Yields of the Monoamidated Product in Metal-Catalyzed C-H Amidation of 2-Phenylpyridine with Arylisocyanates. J. Org. Chem. 85:2680-2687.

McIndoe JS, Vikse KL. 2019. Assigning the ESI mass spectra of organometallic and coordination compounds. J. Mass Spectrom. 54:466-479.

McMurry J. 2008. Organic Chemistry. 7th Ed. Belmont USA: Brooks/Cole.

This article is protected by copyright. All rights reserved. 
McNally A, Prier CK, MacMillan DWC. 2011. Discovery of an $\alpha$-Amino C-H Arylation Reaction Using the Strategy of Accelerated Serendipity. Science 334:11141117.

Miao J, Ge H. 2014. Palladium-catalyzed decarboxylative cross-coupling of $\alpha$ oxocarboxylic acids and their derivatives. Synlett 25:911-919.

Miller GBS, Esser TK, Knorke H, Gewinner S, Schoellkopf W, Heine N, Asmis KR, Uggerud E. 2014. Spectroscopic Identification of a Bidentate Binding Motif in the Anionic Magnesium- $\mathrm{CO}_{2}$ Complex $\left(\left[\mathrm{ClMgCO}_{2}\right]^{-}\right)$. Angew. Chem., Int. Ed. 53:1440714410.

Miller GBS, Uggerud E. 2018. C-C Bond Formation of Mg- and Zn-Activated Carbon Dioxide. Chem. Eur. J. 24:4710-4717.

Miyashita A, Yamamoto T, Yamamoto A. 1977. Thermal stability of alkylcopper(I) complexes coordinated with tertiary phosphines. Bull. Chem. Soc. Jpn. 50:1109-1117.

Moon PJ, Lundgren RJ. 2020. Metal-Catalyzed Ionic Decarboxylative Cross-Coupling Reactions of $\left(\mathrm{sp}^{3}\right)$ Acids: Reaction Development, Mechanisms, and Application. ACS Catal. 10:1742-1753.

Müller CA, Markert C, Teichert AM, Pfaltz A. 2009. Mass spectrometric screening of chiral catalysts and catalyst mixtures. Chem. Commun. 1607-1618.

Noor A, Li J, Khairallah GN, Li Z, Ghari H, Canty AJ, Ariafard A, Donnelly PS, O'Hair RAJ. 2017. A one-pot route to thioamides discovered by gas-phase studies: palladiummediated $\mathrm{CO}_{2}$ extrusion followed by insertion of isothiocyanates. Chem. Commun. $53: 3854-3857$.

Nunez Magro AA, Eastham GR, Cole-Hamilton DJ. 2009. Preparation of phenolic compounds by decarboxylation of hydroxybenzoic acids or desulfonation of hydroxybenzenesulfonic acid, catalysed by electron rich palladium complexes. Dalton Trans.:4683-4688.

O'Hair RAJ. 2006. The 3D quadrupole ion trap mass spectrometer as a complete chemical laboratory for fundamental gas-phase studies of metal mediated chemistry. Chem. Commun. 1469-1481.

O'Hair RAJ. 2010. Gas phase ligand fragmentation to unmask reactive metallic species. In In Reactive Intermediates, Santos LS Editor, Wiley-VCH, Chapter 6, 199-227.

O'Hair RAJ. 2015. Mass spectrometry based studies of gas phase metal catalyzed reactions. Int. J. Mass Spectrom. 377:121-129.

O'Hair RAJ. 2015. Gas-phase studies of metal catalyzed decarboxylative crosscoupling reactions of esters. Pure Appl. Chem. 87:391-404.

O'Hair RAJ, Khairallah GN. 2004. Gas Phase Ion Chemistry of Transition Metal Clusters: Production, Reactivity, and Catalysis. J. Cluster Sci. 15:331-363.

This article is protected by copyright. All rights reserved. 
O’Hair RAJ, Mravak A, Krstić M, Bonačić-Koutecký V. 2019. Models facilitating the design of a new metal-organic framework catalyst for the selective decomposition of formic acid into hydrogen and carbon dioxide, ChemCatChem, 11: 2443-2448.

O'Hair RAJ, Rijs NJ. 2015. Gas phase studies of the Pesci decarboxylation reaction: Synthesis, structure, and unimolecular and bimolecular reactivity of organometallic ions. Acc. Chem. Res. 48:329-340.

O'Hair RAJ, Vrkic AK, James PF. 2004. Gas-phase synthesis and reactivity of the organomagnesates $\left[\mathrm{CH}_{3} \mathrm{MgL}_{2}\right]^{-}\left(\mathrm{L}=\mathrm{Cl}\right.$ and $\left.\mathrm{O}_{2} \mathrm{CCH}_{3}\right)$ : from ligand effects to catalysis. J. Am. Chem. Soc. 126:12173-12183.

Ortuno MA, Conejero S, Lledos A. 2013. True and masked three-coordinate T-shaped platinum(II) intermediates. Beilstein J. Org. Chem. 9:1352-1382, 1331 pp.

Ortuño MA, Dereli B, Cramer CJ. 2016. Mechanism of Pd-Catalyzed Decarbonylation of Biomass-Derived Hydrocinnamic Acid to Styrene following Activation as an Anhydride. Inorg. Chem. 55:4124-4131.

Ozin GA, Gil C. 1989. Intrazeolite organometallics and coordination complexes: internal versus external confinement of metal guests. Chem. Rev. 89: 1749-1764

Pacchioni G. 2014. Ketonization of Carboxylic Acids in Biomass Conversion over $\mathrm{TiO}_{2}$ and $\mathrm{ZrO}_{2}$ Surfaces: A DFT Perspective. ACS Catal. 4:2874-2888.

Pandey KK. 1995. Reactivities of carbonyl sulfide (COS), carbon disulfide $\left(\mathrm{CS}_{2}\right)$ and carbon dioxide $\left(\mathrm{CO}_{2}\right)$ with transition metal complexes. Coordination Chemistry Reviews 140:37-114.

Park K, Lee S. 2013. Transition metal-catalyzed decarboxylative coupling reactions of alkynyl carboxylic acids. RSC Adv. 3:14165-14182.

Park J, Park E, Kim A, Park S-A, Lee Y, Chi K-W, Jung YH, Kim IS. 2011. PdCatalyzed Decarboxylative Coupling of Propiolic Acids: One-Pot Synthesis of 1,4Disubstituted 1,3-Diynes via Sonogashira-Homocoupling Sequence. J. Org. Chem. 76:2214-2219.

Patai S, Editor. 1992. Supplement B: The Chemistry of Acid Derivatives, Vol. 2, Wiley.

Patra T, Maiti D. 2017. Decarboxylation as the Key Step in C-C Bond-Forming Reactions. Chem. Eur. J. 23:7382-7401.

Perry GJP, Larrosa I. 2017. Recent Progress in Decarboxylative Oxidative CrossCoupling for Biaryl Synthesis. Eur. J. Org. Chem. 2017:3517-3527.

Pham TN, Sooknoi T, Crossley SP, Resasco DE. 2013. Ketonization of Carboxylic Acids: Mechanisms, Catalysts, and Implications for Biomass Conversion. ACS Catal. $3: 2456-2473$.

Prince RH, Raspin KA. 1966. Olefin formation from saturated aldehydes and acids by reaction with ruthenium and rhodium complexes. Chem. Comm. 156-157.

This article is protected by copyright. All rights reserved. 
Pulido A, Oliver-Tomas B, Renz M, Boronat M, Corma A. 2013. Ketonic Decarboxylation Reaction Mechanism: A Combined Experimental and DFT Study. ChemSusChem 6:141-151.

Qian R, Guo H, Liao Y, Wang H, Zhang X, Guo Y. 2006. Studies of gas-phase fragmentation reactions of $\left[\mathrm{Pd}\left(\mathrm{PPh}_{3}\right)_{2}(\mathrm{OCOR})\right]^{+}$by electrospray ionization Fourier transform ion cyclotron resonance mass spectrometry. Rapid Commun Mass Spectrom 20:589-594.

Rappoport Z, Marek I, Editors. 2009. The Chemistry of Organocopper Compounds: Part 1: John Wiley \& Sons Ltd.

Richardson DE, Plattner DA. 2007. Organometallic chemistry in the gas phase. In Comprehensive Organometallic Chemistry III, Vol 1, 801-822.

Rijs N, Khairallah GN, Waters T, O'Hair RAJ. 2008. Gas-Phase Synthesis of the Homo and Hetero Organocuprate Anions $[\mathrm{MeCuMe}]^{-}$, [EtCuEt]', and [MeCuR] $]^{-}$. J. Am. Chem. Soc. 130:1069-1079.

Rijs NJ, O'Hair RAJ. 2009. Gas-Phase Synthesis of Organoargenate Anions and Comparisons with Their Organocuprate Analogues. Organometallics 28:2684-2692.

Rijs NJ, O'Hair RAJ. 2010. Unimolecular Reactions of Organocuprates and Organoargentates. Organometallics 29:2282-2291.

Rijs NJ, O'Hair RAJ. 2012. Dimethylcuprate-catalyzed decarboxylative coupling of allyl acetate. Organometallics 31:8012-8023.

Rijs NJ, Sanvido GB, Khairallah GN, O'Hair RAJ. 2010. Gas phase synthesis and reactivity of dimethylaurate. Dalton Trans. 39:8655-8662.

Rijs NJ, Yates BF, O'Hair RAJ. 2010. Dimethyl cuprate Undergoes a Dyotropic Rearrangement. Chem. Eur. J. 16:2674-2678.

Rijs NJ, Yoshikai N, Nakamura E, O'Hair RAJ. 2014. Unraveling Organocuprate Complexity: Fundamental Insights into Intrinsic Group Transfer Selectivity in Alkylation Reactions. J. Org. Chem. 79:1320-1334.

Rijs NJ, Yoshikai N, Nakamura E, O'Hair RAJ. 2012. Gas-Phase Reactivity of Group 11 Dimethylmetallates with Allyl Iodide. J. Am. Chem. Soc. 134:2569-2580.

Rodgers MT, Armentrout PB. 2004A, Gas Phase Coordination Chemistry. In Comprehensive Coordination Chemistry II: From Biology to Nanotechnology. Volume 2: Fundamentals, Lever, A. B. P., Ed.; Elsevier: Dordrecht, 141-158.

Rodgers MT, Armentrout PB. 2004B. A Thermodynamic "Vocabulary" for Metal Ion Interactions in Biological Systems. Acc. Chem. Res. 37:989-998.

Rodgers MT, Armentrout PB. 2016. Cationic Noncovalent Interactions: Energetics and Periodic Trends. Chem. Rev. 116:5642-5687.

This article is protected by copyright. All rights reserved. 
Rodriguez N, Goossen LJ. 2011. Decarboxylative coupling reactions: a modern strategy for C-C-bond formation. Chem. Soc. Rev. 40:5030-5048.

Rodriguez-Blanco G, Jobst KJ, Luider TM, Terlouw JK, Burgers PC. 2013. Generation and Dissociation of $\mathrm{RCOOCaCl}_{2}{ }^{-}$and other Carboxylate-Substituted Superhalogens: $\mathrm{CO}_{2}$ Capture and Implications for Structure Analysis. ChemPlusChem 78:1184-1189.

Roithová J. 2012. Characterization of reaction intermediates by ion spectroscopy. Chem. Soc. Rev. 41:547-559.

Roithová J, Gray A, Andris E, Jasik J, Gerlich D. 2016. Helium Tagging Infrared Photodissociation Spectroscopy of Reactive Ions. Acc. Chem. Res. 49:223-230.

Roithová J, Schröder D. 2010. Selective Activation of Alkanes by Gas-Phase Metal Ions. Chem. Rev. 110:1170-1211.

Ruhland K. 2012. Transition-Metal-Mediated Cleavage and Activation of C-C Single Bonds. Eur. J. Org. Chem. 2012:2683-2706.

Rydfjord J, Svensson F, Trejos A, Sjoeberg PJR, Skoeld C, Saevmarker J, Odell LR, Larhed M. 2013. Decarboxylative Palladium(II)-Catalyzed Synthesis of Aryl Amidines from Aryl Carboxylic Acids: Development and Mechanistic Investigation. Chem. Eur. J. 19:13803-13810.

Sambiagio C, Schönbauer D, Blieck R, Dao-Huy T, Pototschnig G, SchaafP, Wiesinger T, Zia MF, Wencel-Delord J, Besset T, Maes BUW, Schnürch M. 2018. A comprehensive overview of directing groups applied in metal-catalysed $\mathrm{C}-\mathrm{H}$ functionalisation chemistry. Chem. Soc. Rev. 47:6603-6743.

Sandfort F, O'Neill MJ, Cornella J, Wimmer L, Baran PS. 2017. Alkyl-(Hetero)Aryl Bond Formation via Decarboxylative Cross-Coupling: A Systematic Analysis. Angew. Chem., Int. Ed. 56:3319-3323.

Sanjosé-Orduna J, Mudarra ÁL, Martínez de Salinas S, Pérez-Temprano MH. 2019. Sustainable Knowledge-Driven Approaches in Transition-Metal-Catalyzed Transformations. ChemSusChem 12:2882-2897.

Santillan-Jimenez E, Crocker M. 2012. Catalytic deoxygenation of fatty acids and their derivatives to hydrocarbon fuels via decarboxylation/decarbonylation. J. Chem. Tech. Biotech. 87:1041-1050.

Santos LS. 2008. Online mechanistic investigations of catalyzed reactions by electrospray ionization mass spectrometry: a tool to intercept transient species in solution. Eur. J. Org. Chem.:235-253.

Santos LS, Ed. 2010A. Reactive Intermediates: MS Investigations In Solution: WileyVCH Verlag GmbH \& Co. KGaA.

Santos LS. 2010B, in Reactive Intermediates: MS Investigations In Solution: WileyVCH Verlag GmbH \& Co. KGaA, 133-198.

Satoh T, Miura M. 2016, pp 119-163.

This article is protected by copyright. All rights reserved. 
Schmidt A, Beutler A, Albrecht M, Snovydovych B, Ramírez FJ. 2008. Imidazol-2and-4-ylidene by decarboxylation. Studies on the cross-conjugated mesomeric betainealkaloid norzooanemonine and its pseudo-cross-conjugated isomer. Org. Biomol. Chem. 6:287-295.

Schröder D. 2012. Applications of Electrospray Ionization Mass Spectrometry in Mechanistic Studies and Catalysis Research. Acc. Chem. Res. 45:1521-1532.

Schröder D, Schwarz H. 2008. Gas-phase activation of methane by ligated transitionmetal cations. Proc. Natl. Acad. Sci. U. S. A. 105:18114-18119.

Schwarz H. 1989. Remote functionalization of C-H and C-C bonds by "naked" transition-metal ions (Cosi Fan Tutte). Acc. Chem. Res. 22:282-287.

Schwarz H. 2011. Chemistry with Methane: Concepts Rather than Recipes. Angew. Chem., Int. Ed. 50:10096-10115.

Schwarz H. 2014. How and Why Do Cluster Size, Charge State, and Ligands Affect the Course of Metal-Mediated Gas-Phase Activation of Methane? Isr. J. Chem. 54:1413-1431.

Schwarz H. 2015A. Doping Effects in Cluster-Mediated Bond Activation. Angew. Chem., Int. Ed. 54:10090-10100.

Schwarz H. 2015B. Thermal hydrogen-atom transfer from methane: A mechanistic exercise. Chem. Phys. Lett. 629:91-101.

Schwarz H. 2017A. Ménage-á-trois: single-atom catalysis, mass spectrometry, and computational chemistry. Catal. Sci. Technol. 7:4302-4314.

Schwarz H. 2017B. Metal-mediated activation of carbon dioxide in the gas phase: Mechanistic insight derived from a combined experimental/computational approach. Coord. Chem. Rev. 334:112-123.

Schwarz H, Gonzalez-Navarrete P, Li J, Schlangen M, Sun X, Weiske T, Zhou S. 2017. Unexpected Mechanistic Variants in the Thermal Gas-Phase Activation of Methane. Organometallics 36:8-17.

Schröder D, Zummack W, Schwarz H. 1994. Reaction Products, Directionalities, and mechanisms of Iron(I)-Mediated $\mathrm{CH}-$, CC-, and CO-Bond Activation of Aliphatic Carboxylic Acids in the Gas Phase. J. Am. Chem. Soc. 116:5857-5864.

Schlangen M, Schröder D, Schwarz H. 2005. Gas-phase reactions of homo- and heteronuclear clusters $\mathrm{MM}^{\prime}+\left(\mathrm{M}, \mathrm{M}^{\prime}=\mathrm{Fe}, \mathrm{Co}, \mathrm{Ni}\right)$ with linear alkanenitriles. Helv. Chim. Acta 88:1405-1420.

Shaffer CJ, Schröder D, Gütz C, Lützen A. 2012. Intramolecular C-H Bond Activation through a Flexible Ester Linkage. Angew. Chem., Int. Ed. 51:8097-8100.

Shang R, Liu L. 2011. Transition metal-catalyzed decarboxylative cross-coupling reactions. Sci. China: Chem. 54:1670-1687.

This article is protected by copyright. All rights reserved. 
Shanklin J, Cahoon EB. 1998. Desaturation and related modifications of fatty acids. Annu. Rev. Plant Physiol. Plant Mol. Biol. 49:611-641.

Shanklin J, Guy JE, Mishra G, Lindqvist Y. 2009. Desaturases: Emerging models for understanding functional diversification of diiron-containing enzymes. J. Biol. Chem. 284:18559-18563.

Shepard AF, Winslow NR, Johnson JR. 1930. Simple halogen derivatives of furan. J. Am. Chem. Soc. 52:2083-2090.

Sherden NH, Behenna DC, Virgil SC, Stoltz BM. 2009. Unusual Allylpalladium Carboxylate Complexes: Identification of the Resting State of Catalytic Enantioselective Decarboxylative Allylic Alkylation Reactions of Ketones. Angew. Chem., Int. Ed. 48:6840-6843.

Shul'pin GB. 2013. C-H functionalization: thoroughly tuning ligands at a metal ion, a chemist can greatly enhance catalyst's activity and selectivity. Dalton Trans. 42:1279412818.

Shutova TG, Butovskaya GV, Agabekov VE, Moiseichuk KL. 1996. Radical formation during 3-methyl-3-tert-butylperoxy-1-butynylsilver thermal decomposition. Kinet. Catal. 37:29-34.

Siemsen P, Livingston RC, Diederich F. 2000. Acetylenic coupling: a powerful tool in molecular construction. Angew. Chem., Int. Ed. 39:2632-2657.

Simoes JAM, Beauchamp JL. 1990. Transition metal-hydrogen and metal-carbon bond strengths: the keys to catalysis. Chem. Rev. 90:629-688.

Smith GG, Kelly FW. 1971. Structure-reactivity relations in homogeneous gas-phase reactions. Thermolyses and rearrangements. Progr. Phys. Org. Chem. 8:75-234.

Stepnowski RM, Allison J. 1988. Gas-phase chemistry of first-row transition-metaland metal-containing ions with alkyl cyanides. Organometallics 7:2097-2103.

Stoddard RL, Luo J, van der Wal N, O'Rourke NF, Wulff JE, McIndoe JS. 2014. A multi-pronged mechanistic study of the phosphine-mediated conjugate addition of an alcohol to an acetylenic ester. New J. Chem. 38:5382-5390.

Stöckigt D, Sen S, Schwarz H. 1994. Association reactions and remote C-H bond activation of aliphatic nitriles with $\mathrm{Fe}\left(\mathrm{CH}_{3}\right)^{+}$. Organometallics 13:1465-1469.

Stoltz BM, Goddard WA. 2012. The Reaction Mechanism of the Enantioselective Tsuji Allylation: Inner-Sphere and Outer-Sphere Pathways, Internal Rearrangements, and Asymmetric C-C Bond Formation. J. Am. Chem. Soc. 134:19050-19060.

Sun X, Chen J, Ritter T. 2018. Catalytic dehydrogenative decarboxyolefination of carboxylic acids. Nature Chem. 10:1229-1233.

Takise R, Muto K, Yamaguchi J. 2017. Cross-coupling of aromatic esters and amides. Chem. Soc. Rev. 46:5864-5888.

This article is protected by copyright. All rights reserved. 
Tang J, Hackenberger D, Goossen LJ. 2016. Branched Arylalkenes from Cinnamates: Selectivity Inversion in Heck Reactions by Carboxylates as Deciduous Directing Groups. Angew. Chem., Int. Ed. 55:11296-11299.

Theron R, Wu Y, Yunker LPE, Hesketh AV, Pernik I, Weller AS, McIndoe JS. 2016. Simultaneous Orthogonal Methods for the Real-Time Analysis of Catalytic Reactions. ACS Catal. 6:6911-6917.

Thomas GT, Janusson E, Zijlstra HS, McIndoe JS. 2019. Step-by-step real time monitoring of a catalytic amination reaction. Chem. Commun. 55:11727-11730.

Tidwell TT. 1995. Ketenes: Wiley.

Toy XY, Bin Roslan II, Chuah GK, Jaenicke S. 2014. Protodecarboxylation of carboxylic acids over heterogeneous silver catalysts. Catal. Sci. Technol. 4:516-523.

Traeger JC. 2000. Electrospray mass spectrometry of organometallic compounds. Int. J. Mass Spectrom. 200:387-401.

Vana J, Bartacek J, Hanusek J, Roithová J, Sedlak M. 2019. C-H Functionalizations by Palladium Carboxylates: The Acid Effect. J. Org. Chem. 84:12746-12754.

Verkruijsse HD, Brandsma L. 1987. Carbophilic versus thiophilic attack in the reaction of metallated aromates and heteroaromates with carbon disulfide. J. Organomet. Chem. 332:95-98.

Vikse KL, Ahmadi Z, Manning CC, Harrington DA, McIndoe JS. 2011. Powerful Insight into Catalytic Mechanisms through Simultaneous Monitoring of Reactants, Products, and Intermediates. Angew. Chem., Int. Ed. 50:8304-8306.

Vikse KL, Ahmadi Z, Scott McIndoe J. 2014. The application of electrospray ionization mass spectrometry to homogeneous catalysis. Coord. Chem. Rev. 279:96-114.

Vikse KL, Khairallah GN, O'Hair RAJ. 2012. Gas-Phase Unimolecular Reactions of Pallada- and Nickelalactone Anions. Organometallics 31:7467-7475.

Vikse KL, McIndoe JS. 2015. Mechanistic insights from mass spectrometry: examination of the elementary steps of catalytic reactions in the gas phase. Pure Appl. Chem. 87:361-377.

Vikse KL, Woods MP, McIndoe JS. 2010. Pressurized Sample Infusion for the Continuous Analysis of Air- And Moisture-Sensitive Reactions Using Electrospray Ionization Mass Spectrometry. Organometallics 29:6615-6618.

Wang Z, Wang X, Nishihara Y. 2020. Nickel or Palladium-Catalyzed Decarbonylative Transformations of Carboxylic Acid Derivatives. Chem. Asian J.15:1234-1247.

Waters T, O'Hair RAJ, Wedd AG. 2000. Probing the catalytic oxidation of alcohols via an anionic dimolybdate center using multistage mass spectrometry. Chem. Commun. 225-226.

This article is protected by copyright. All rights reserved. 
Waters T, O'Hair RAJ, Wedd AG. 2003A. Catalytic gas phase dehydration of acetic acid to ketene. Int. J. Mass Spectrom. 228:599-611.

Waters T, O'Hair RAJ, Wedd AG. 2003B. Catalytic Gas Phase Oxidation of Methanol to Formaldehyde. J. Am. Chem. Soc. 125:3384-3396.

Weaver JD, Recio A, Grenning AJ, Tunge JA. 2011. Transition Metal-Catalyzed Decarboxylative Allylation and Benzylation Reactions. Chem. Rev. 111:1846-1913.

Weragoda GK, Pilkington RL, Polyzos A, O'Hair RAJO. 2018. Regioselectivity of aryl radical attack onto isocyanates and isothiocyanates. Org. Biomol. Chem. 16: 9011 9020.

Westmijze H, Kleijn H, Meijer J, Vermeer P. 1979. Synthesis of Dithioesters from Organocopper(I) Compounds. Synthesis 1979:432-434.

White MC. 2012A. Adding aliphatic C-H bond oxidations to synthesis. Science 335:807-809.

White MC. 2012B. C-H bond functionalization \& synthesis in the 21 st century: a brief history and prospectus. Synlett 23:2746-2748.

Whitesides GM, Bergbreiter DE, Kendall PE. 1974. Preparation and thermal decomposition of $n$-alkyl(tri- $n$-butylphosphine)silver(I) reagents. J. Am. Chem. Soc. 96:2806-2813.

Whitesides GM, Panek EJ, Stedronsky ER. 1972. Radical intermediates in the thermal decomposition of neophyl(tri- $n$-butylphosphine)copper(I) and neophyl(tri- $n$ butylphosphine)silver(I). J. Am. Chem. Soc. 94:232-239.

Whitesides GM, Stedronsky ER, Casey CP, San Filippo J. 1970. Mechanism of thermal decomposition of n-butyl(tri- $n$-butylphosphine) copper(I). J. Am. Chem. Soc. 92:14261427.

Whittemore SM, Yoder RJ, Stambuli JP. 2012. Site-Selective Alkyl Dehydrogenation of a Coordinated Acylphosphine Ligand. Organometallics 31:6124-6130.

Woolley M, Ariafard A, Khairallah GN, Kwan KH-Y, Donnelly PS, White JM, Canty AJ, Yates BF, O'Hair RAJ. 2014. Decarboxylative-Coupling of Allyl Acetate Catalyzed by Group 10 Organometallics, [(phen) $\left.\mathrm{M}\left(\mathrm{CH}_{3}\right)\right]^{+}$. J. Org. Chem. 79:12056-12069.

Woolley M, Khairallah GN, da Silva G, Donnelly PS, O'Hair RAJ. 2014. Direct versus Water-Mediated Protodecarboxylation of Acetic Acid Catalyzed by Group 10 Carboxylates, $\left[(\text { phen }) \mathrm{M}_{(}\left(\mathrm{O}_{2} \mathrm{CCH}_{3}\right)\right]^{+}$. Organometallics 33:5185-5197.

Woolley MJ, Khairallah GN, da Silva G, Donnelly PS, Yates BF, O'Hair RAJ. 2013. Role of the Metal, Ligand, and Alkyl/Aryl Group in the Hydrolysis Reactions of Group 10 Organometallic Cations [(L)M(R)] . Organometallics 32:6931-6944.

Xue L, Su W, Lin Z. 2011. Mechanism of silver- and copper-catalyzed decarboxylation reactions of aryl carboxylic acids. Dalton Trans. 40:11926-11936.

This article is protected by copyright. All rights reserved. 
Yamamoto K, Nakanishi K, Kumada M. 1967. The reaction of organosilymethylmagnesium chlorides with silver halides. J. Organomet. Chem. 7:197202.

Yang Y, Canty AJ, McKay AI, Donnelly PS, O'Hair RAJ. 2020. Palladium-Mediated $\mathrm{CO}_{2}$ Extrusion Followed by Insertion of Isocyanates for the Synthesis of Benzamides: Translating Fundamental Mechanistic Studies To Develop a Catalytic Protocol. Organometallics 39:453-467.

Yang Y, Canty AJ, O’Hair RAJ. 2020. Gas-phase studies of copper(I)-mediated $\mathrm{CO}_{2}$ extrusion followed by insertion of $\mathrm{CS}_{2}$ or phenylisocyanate. J. Mass Spectrom. in press (https://doi.org/10.1002/jms.4579).

Yang Y, Noor A, Canty AJ, Ariafard A, Donnelly PS, O’Hair RAJ. 2019. Synthesis of Amidines by Palladium-Mediated $\mathrm{CO}_{2}$ Extrusion Followed by Insertion of Carbodiimides: Translating Mechanistic Studies to Develop a One-Pot Method. Organometallics 38:424-435.

Yoshikai N, Nakamura E. 2012. Mechanisms of Nucleophilic Organocopper(I) Reactions. Chem. Rev. 112:2339-2372.

Yunker LPE, Ahmadi Z, Logan JR, Wu W, Li T, Martindale A, Oliver AG, McIndoe JS. 2018. Real-Time Mass Spectrometric Investigations into the Mechanism of the Suzuki-Miyaura Reaction. Organometallics 37:4297-4308.

Yunker LPE, Stoddard RL, McIndoe JS. 2014. Practical approaches to the ESI-MS analysis of catalytic reactions. J. Mass Spectrom. 49:1-8.

Zavras A, Khairallah GN, Krstić M, Girod M, Daly S, Antoine R, Dugourd P, Maitre P, Mulder RJ, Alexander S-A, Bonačić-Koutecký V, O'Hair RAJ. 2016. Ligandinduced substrate steering and reshaping of $\left[\mathrm{Ag}_{2}(\mathrm{H})\right]^{+}$scaffold for selective $\mathrm{CO}_{2}$ extrusion from formic acid. Nat. Commun. 7:11746.

Zavras A, Krstić M, Dugourd P, Bonačić-Koutecký V, O'Hair RAJ. 2017. Selectivity Effects in Bimetallic Catalysis: Role of the Metal Sites in the Decomposition of Formic Acid into $\mathrm{H} 2$ and $\mathrm{CO}_{2}$ by the Coinage Metal Binuclear Complexes [dppmMM'(H)] ${ }^{+}$. ChemCatChem 9:1298-1302.

Zavras A, White JM, O'Hair RAJ. 2016. An unusual co-crystal $\left[\left(\mu_{2}-\mathrm{dcpm}\right) \mathrm{Ag}_{2}\left(\mu_{2}-\right.\right.$ $\left.\left.\mathrm{O}_{2} \mathrm{CH}\right)\left(\eta_{2}-\mathrm{NO}_{3}\right)\right]_{2} \cdot\left[\left(\mu_{2}-\mathrm{dcpm}\right)_{2} \mathrm{Ag}_{4}\left(\mu_{2}-\mathrm{NO}_{3}\right)_{4}\right]$ and its connection to the selective decarboxylation of formic acid in the gas phase. Dalton Trans. 45:19408-19415.

Zhang S-L, Fu Y, Shang R, Guo Q-X, Liu L. 2010. Theoretical Analysis of Factors Controlling Pd-Catalyzed Decarboxylative Coupling of Carboxylic Acids with Olefins. J. Am. Chem. Soc. 132:638-646.

Zhang X, Jordan F, Szostak M. 2018. Transition-metal-catalyzed decarbonylation of carboxylic acids to olefins: exploiting acyl $\mathrm{C}-\mathrm{O}$ activation for the production of high value products. Org. Chem. Front. 5:2515-2521.

This article is protected by copyright. All rights reserved. 
Zhao C, Brück T, Lercher JA. 2013. Catalytic deoxygenation of microalgae oil to green hydrocarbons. Green Chem. 15:1720-1739.

\section{Biography}

Richard A. J. O'Hair studied Chemistry at the University of Adelaide, where he received $\mathrm{BSc}(\mathrm{Hons}), \mathrm{PhD}$ and $\mathrm{DSc}$ degrees under the research mentorship of Professor John H. Bowie. He carried out post-doctoral research with Professor Roger Truscott at the University of Wollongong and with the late Professor Chuck DePuy at the University of Colorado at Boulder. Richard started his independent research career in 1993 as an Assistant Professor in the Department of Chemistry at Kansas State University, before moving to the School of Chemistry at the University of Melbourne in 1996, where he has risen in the ranks from Senior Lecture to full Professor. Richard uses mass spectrometry as a key discovery tool to (i) explore key reactive intermediates of relevance to organic and organonometallic chemistry; (ii) in bioanalytical applications. He has published over 300 research papers. He is a fellow of the the Royal Australian Chemical Institute (FRACI) and the Australian and New Zealand Society for Mass Spectrometry (FANZSMS). Richard is an associate editor of the Journal of the American Society for Mass Spectrometry; serves on several Editorial Advisory Boards and has been a visiting Professor at the Universités Pierre et Marie Curie, Paris (with Professor Jean-Claude Tabet) and Claude Bernard, Lyon (with Professor Philippe Dugourd). In late 2016 he undertook a six month Senior Humboldt Fellowship with Prof. Konrad Koszinowski (Institut für Organische und Biomolekulare Chemie, GeorgAugust-Universität Göttingen).

This article is protected by copyright. All rights reserved. 


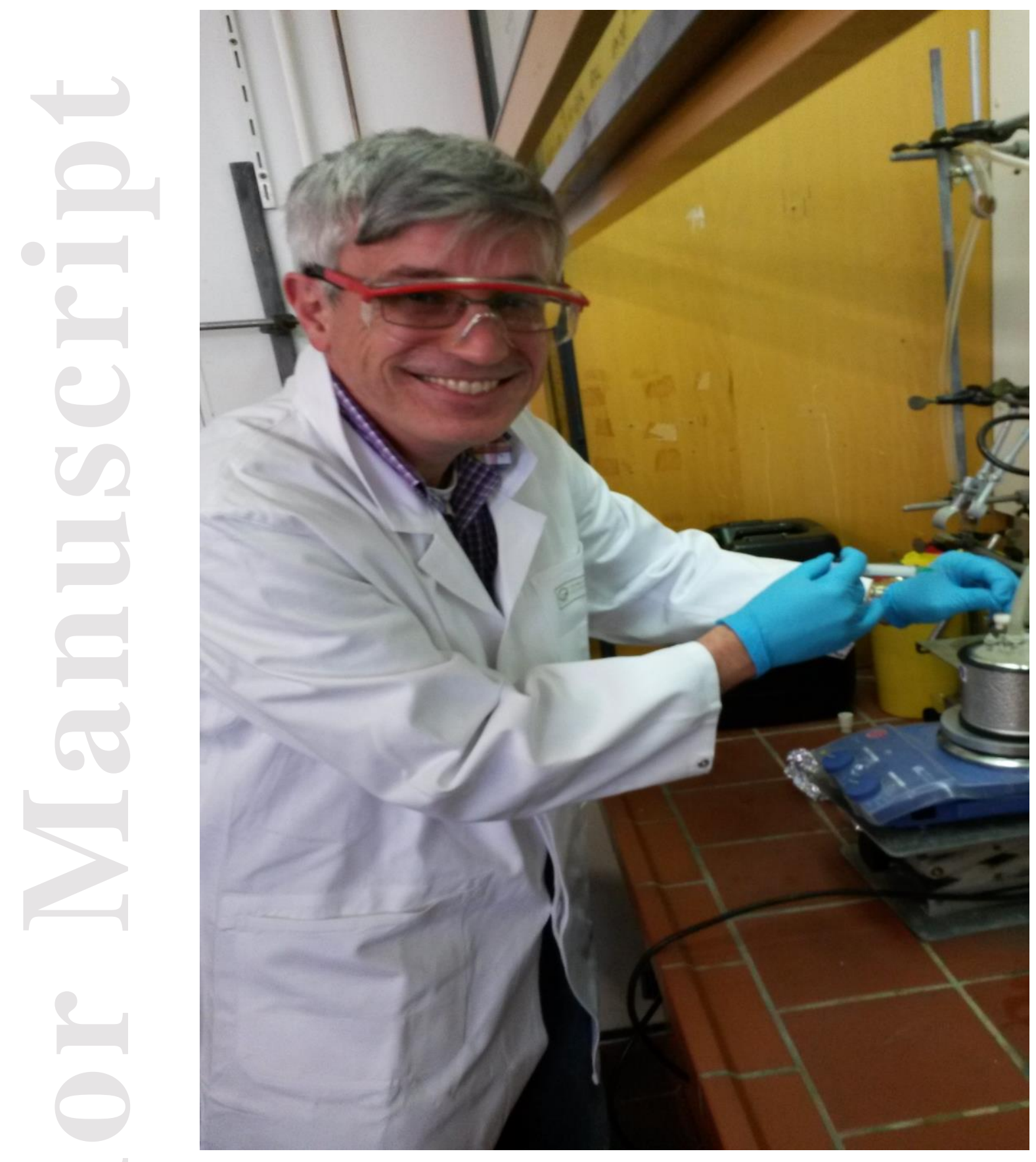

This article is protected by copyright. All rights reserved. 


\section{University Library}

\section{$\bullet-\underset{A C C E S S}{M} \operatorname{N} E R V A$}

\section{A gateway to Melbourne's research publications}

Minerva Access is the Institutional Repository of The University of Melbourne

Author/s:

O'Hair, RAJ

Title:

ORGANOMETALLIC GAS-PHASE ION CHEMISTRY AND CATALYSIS: INSIGHTS INTO THE USE OF METAL CATALYSTS TO PROMOTE SELECTIVITY IN THE REACTIONS OF CARBOXYLIC ACIDS AND THEIR DERIVATIVES

Date:

2020-09-23

Citation:

O'Hair, R. A. J. (2020). ORGANOMETALLIC GAS-PHASE ION CHEMISTRY AND CATALYSIS: INSIGHTS INTO THE USE OF METAL CATALYSTS TO PROMOTE SELECTIVITY IN THE REACTIONS OF CARBOXYLIC ACIDS AND THEIR DERIVATIVES. MASS SPECTROMETRY REVIEWS, 40 (6), pp.782-810. https://doi.org/10.1002/mas.21654.

Persistent Link:

http://hdl.handle.net/11343/276346 